\title{
Electrochemically selective ammonia extraction from nitrate by coupling electron- and phase-transfer reactions at a three-phase interface
}

a School of Environmental and Municipal Engineering, Qingdao University of Technology, Qingdao 266033, P.R. China

${ }^{b}$ Department of Civil and Environmental Engineering, New Jersey Institute of Technology, Newark, New Jersey, 07102, United States

*Corresponding author: bjiang86upc@163.com (Bo Jiang)

16

\section{Summary: 83 pages, 50 figures, 8 tables}

18

9

20


35 Part S1. Chemicals and Materials.

36 Part S2. Preparation of a-Co(OH $)_{2} / \mathrm{Ti}$ mesh.

37 Part S3. Preparation of $\mathrm{CoP} / \mathrm{Ti}$ and over phosphatized $\mathrm{CoP} / \mathrm{Ti}$ mesh.

38 Part S4. Preparation of $\mathrm{Co}_{3} \mathrm{O}_{4} / \mathrm{Ti}$ and $\mathrm{P}-\mathrm{Co}_{3} \mathrm{O}_{4} / \mathrm{Ti}$ mesh.

Part S5. Preparation of $\mathrm{Pd}-\mathrm{Cu} / \mathrm{Ti}$ and $\mathrm{Cu} / \mathrm{Ti}$ mesh.

$40 \quad$ Part S6. Electrochemical measurements.

$41 \quad$ Part S7. Analytical Method.

42 Part S8. Nitrogen species interference detection.

43 Part S9. Calculations of efficiencies.

44 Part S10. Calculations of Faraday efficiency and energy consumption.

45 Part S11. Interfacial pH calculation.

46 Part S12. IR compensation.

47 Part S13. DFT calculations.

48 Part 14. Normalized peak current density calculations.

$49 \quad$ Part 15. Co leaching test.

50 Figure S1. Schematic diagram of ENRRA reaction.

51 Figure S2. Figure of system construction.

52 Figure S3. ENRRA reactor in working condition.

$53 \quad$ Figure S4. Ammonia recovery comparation with and without gas tube.

54 Figure S5. Typical response current curve of $\mathrm{Co}(\mathrm{OH})_{2}$ nanosheet array prepared by cyclic voltammetry 55 electrodeposition.

$56 \quad$ Figure S6. The physical images of self-supported cobalt hydroxide precursors.

57 Figure S7. The physical images of $\mathrm{CoP}, \mathrm{Co}(\mathrm{OH})_{2}$, and Ti mesh.

58 Figure S8. SEM images of $\mathrm{Co}(\mathrm{OH})_{2}$.

59 Figure S9. SEM images of $\mathrm{Co}_{3} \mathrm{O}_{4}$.

60 Figure S10. SEM images of $\mathrm{P}_{-} \mathrm{Co}_{3} \mathrm{O}_{4}$.

61 Figure S11. SEM images of CoP.

62 Figure S12. SEM images of over phosphatized CoP. 
Figure S13. The elemental mapping images of $\mathrm{P}-\mathrm{Co}_{3} \mathrm{O}_{4}$.

Figure S14. The elemental composition of $\mathrm{P}_{-} \mathrm{Co}_{3} \mathrm{O}_{4}$.

Figure S15. The elemental mapping images of $\mathrm{CoP}$.

Figure S16. The elemental mapping images of over phosphatized CoP.

67 Figure S17. XRD images of different Co-based cathodes.

Figure S18. XPS images of $\mathrm{Co}_{3} \mathrm{O}_{4}$.

Figure S19. XPS images of $\mathrm{P}-\mathrm{Co}_{3} \mathrm{O}_{4}$.

Figure S20. XPS images of CoP.

Figure S21. XPS images of over phosphatized CoP.

Figure S22. The current density of LSV, with or without presence of nitrate ions.

Figure S23. Cyclic voltammograms (CVs) within the non-faraday potential range.

Figure S24. Calculation of double capacitance for different cathodes.

Figure S25. Differential current density based on ESCA normalized linear cyclic voltammetry (LSV) curve.

Figure S26. Tafel plots and exchange current density $\left(\mathrm{j}_{0}\right)$ in $0.1 \mathrm{M} \mathrm{Na}_{2} \mathrm{SO}_{4}(\mathrm{a})$ and $0.5 \mathrm{M} \mathrm{KOH}(\mathrm{b})$.

Figure S27. The comparation of different cathodes.

Figure S28. Nitrate reduction experiments of CoP cathode with and without ammonia separation.

Figure S 29. The effect of FGM pore diameter size.

Figure S30. The contact angle of (a) $0.20 \mu \mathrm{m}$, (b) $0.45 \mu \mathrm{m}$, (c) $1.0 \mu \mathrm{m}$ FGM.

Figure S31. The effect of potential.

Figure S32. The effect of $\mathrm{pH}$.

Figure S33. The effect of $\mathrm{Cl}^{-}$concentration.

Figure S34. The effect of nitrate concentration.

Figure S35. The relationship between current density with interfacial pH of cathode.

Figure S36. The recycle experiments of $\mathrm{CoP}$ fabricated ENRRA reactor.

Figure S37. The treatment of actual printing wastewater.

Figure S38. Nitrate reduction experiments with different t-BuOH/nitrate ratios.

Figure S39. The adsorption of nitrate and $\mathrm{H}$ at different sites on the CoP (211) crystal plane.

Figure S40. The adsorption energy of different nitrogen species on CoP (211). 
92 Figure S41. Structures before and after optimization for $\mathrm{NO}_{3}{ }^{-}$and $\mathrm{NH}_{3}$ on $\mathrm{CoP}(211)$.

$93 \quad$ Figure $\mathbf{S 4 2}$. N species verify.

94 Figure S43. Comparison of Ti and P doped Ti cathode for nitrate reduction.

95 Figure S44. The distance of nearby active sites.

96 Figure $\mathbf{S 4 5}$. The relative energy for $* \mathrm{NO}_{2}$ desorption and reduction at $-0.97 \mathrm{~V}$ and $-1.24 \mathrm{~V}$.

97 Figure S46. The schematic diagram of three electrode and two electrode operations.

98 Figure $\mathbf{S 4 7}$. The compare of bulk $\mathrm{pH}$ with and without $\mathrm{NO}_{3}^{-}$.

99 Figure $\mathbf{S 4 8} . \mathrm{NO}_{2}$ - formation pathways.

100 Figure $\mathbf{S 4 9} . \mathrm{NH}_{3}$ formation pathways.

101 Figure S50. $\mathrm{NO}_{3}{ }^{-}$formation pathways.

102 Table S1. Comparison of the $\mathrm{NO}_{3}{ }^{-}$reduction, $\mathrm{NH}_{3}$ recovery, and $\mathrm{NH}_{3}$ production rate of CoP cathode 103 based ENRRA reactor with other catalysts/methods under ambient conditions.

104 Table S2. The value and normalized value of peak current density and Tafel slope.

105 Table S3. The concentration of N species of Figure 2(f).

106 Table S4. Detail of adsorption free energy for nitrate and H at different sites on the CoP (211) crystal 107 plane.

108 Table S5. The Bader charge calculation results.

109 Table S6. Formation energy barriers of different di-nitrogen species.

110 Table S7. Compare of production/consumption ratio of $\mathrm{OH}^{-} / \mathrm{e}^{-}$.

111 Table S8. Formation energy barriers of $* \mathrm{NOOH}$ to $* \mathrm{NOHOH}$ and $* \mathrm{NO}$. 


\section{Experimental Section}

\section{Part S1. Chemicals and Materials.}

Ti mesh $(>99.99 \%$, pore diameter $0.1 \times 0.1 \mathrm{~mm}$, thickness $0.6 \mathrm{~mm})$ and $\mathrm{IrO}_{2}-\mathrm{RuO}_{2} / \mathrm{Ti}$ plate were purchased from Yunxuan Metallic Materials Co. Ltd. Sodium hypophosphite $\left(\mathrm{NaH}_{2} \mathrm{PO}_{2},>98 \%\right)$, cobalt hexahydrate $\left(\mathrm{Co}\left(\mathrm{NO}_{3}\right)_{2} \cdot 6 \mathrm{H}_{2} \mathrm{O},>99 \%\right)$, potassium iodide $(\mathrm{KI},>99 \%)$, mercuric iodide red $\left(\mathrm{HgI}_{2},>\right.$ $99.5 \%)$, potassium sodium tartrate tetrahydrate $\left(\mathrm{NaKC}_{4} \mathrm{H}_{4} \mathrm{O}_{6} \cdot 4 \mathrm{H}_{2} \mathrm{O},>99 \%\right)$, sulfamic acid $\left(\mathrm{NH}_{2} \mathrm{SO}_{3} \mathrm{H},>\right.$ $99 \%)$, sulfanilamide $\left(\mathrm{C}_{6} \mathrm{H}_{8} \mathrm{~N}_{2} \mathrm{O}_{2} \mathrm{~S},>99 \%\right)$, sodium chloride $(\mathrm{NaCl},>99.5 \%)$, ethanol $(95 \%)$, hexadecyl trimethyl ammonium bromide $\left(\mathrm{C}_{19} \mathrm{H}_{42} \mathrm{BrN},>99 \%\right)$, tert-Butanol $\left(\mathrm{C}_{4} \mathrm{H}_{10} \mathrm{O},>98 \%\right)$, ammonium chloride $\left(\mathrm{NH}_{4} \mathrm{Cl}, 99.8 \%\right)$, potassium nitrate $\left(\mathrm{KNO}_{3},>99.5 \%\right)$, sodium nitrite $\left(\mathrm{NaNO}_{2},>99 \%\right), \mathrm{H}_{2} \mathrm{SO}_{4}(95 \%-98 \%)$, $\mathrm{HCl}(36 \%-38 \%), \mathrm{H}_{3} \mathrm{PO}_{4}(>85 \%), \mathrm{NaOH}(>96 \%)$ were provided by Sinopharm Chemical Reagent Co. Ltd., China. All the reagents were AR and used without further purification. All working solutions were prepared using ultrapure water $(18.2 \mathrm{M} \Omega)$ in this study.

\section{Part S2. Preparation of a-Co(OH) $)_{2} / \mathrm{Ti}$ mesh.}

Before electrodeposition, Ti mesh was firstly polished with 300-mesh emery paper and then boiled in $20 \%$ sulfuric acid to remove the oxide layer. Next, the Ti mesh was cleaned by ethanol and ultrapure water, sonicated for $15 \mathrm{~min}$, and dried for use. The electrodeposition solution contained $0.05 \mathrm{M}$ $\mathrm{Co}\left(\mathrm{NO}_{3}\right)_{2} \cdot 6 \mathrm{H}_{2} \mathrm{O}$. The deposition was carried out in a three-electrode cell configuration by a electrochemical workstation (PGSTAT 302N, Metrohm), using a Pt plate as the counter electrode, saturated calomel electrode (SCE) as the reference electrode, and the cleaned Ti mesh $\left(5 \times 5 \mathrm{~cm}^{2}\right)$ as the working electrode. The electrodeposition of a-Co(OH $)_{2}$ nanosheets film by cyclic voltammetry $(\mathrm{CV})$ was performed within the potential range from $-1.2 \mathrm{~V}$ to $-0.8 \mathrm{~V}$ vs. SCE at a scan rate of $50 \mathrm{mV} \cdot \mathrm{s}^{-1}$. After deposition for 50 scan cycles, the deposited electrode was rinsed first with deionized water, ethanol 
134 several times and then dried at $60{ }^{\circ} \mathrm{C}$ for $12 \mathrm{~h}$ in vacuum oven. The loading for a-Co(OH $)_{2}$ on Ti mesh 135 was determined to be $\sim 0.80 \mathrm{mg} \mathrm{cm}^{-2}$. The possible electrodeposition mechanism for the formation of a$136 \mathrm{Co}(\mathrm{OH})_{2}$ is described by the following equations:

$$
\mathrm{Co}^{2+}+2 \mathrm{OH}^{-} \rightarrow \mathrm{Co}(\mathrm{OH})_{2}
$$

\section{Part S3. Preparation of CoP/Ti and over phosphatized CoP/Ti mesh.}

To synthesize CoP film, the as-prepared a-Co(OH) $2 /$ Ti mesh and $\mathrm{NaH}_{2} \mathrm{PO}_{2} \cdot \mathrm{H}_{2} \mathrm{O}$ were placed at two separate positions in a porcelain boat with $\mathrm{NaH}_{2} \mathrm{PO}_{2} \cdot \mathrm{H}_{2} \mathrm{O}$ at the upstream side of the furnace. The molar ratio of Co to $\mathrm{P}$ was $1: 10$. Subsequently, the sample was heated at $300{ }^{\circ} \mathrm{C}$ for $120 \mathrm{~min}$ in $\mathrm{N}_{2}$ atmosphere, and then cooled to ambient temperature under $\mathrm{N}_{2}$. After that, a black film was observed on Ti mesh. For the purpose of comparison, over phosphatized $\mathrm{CoP} / \mathrm{Ti}$ was synthesized in similar way. But the molar ratio of Co to $\mathrm{P}$ was 1:50. The reaction equation is followed:

$$
2 \mathrm{NaH}_{2} \mathrm{PO}_{2} \cdot \mathrm{H}_{2} \mathrm{O} \rightarrow \mathrm{PH}_{3}+\mathrm{Na}_{2} \mathrm{HPO}_{4}+\mathrm{H}_{2} \mathrm{O}
$$

\section{Part S4. Preparation of $\mathrm{Co}_{3} \mathrm{O}_{4} / \mathrm{Ti}$ and $\mathrm{P}-\mathrm{Co}_{3} \mathrm{O}_{4} / \mathrm{Ti}$ mesh.}

To synthesize $\mathrm{Co}_{3} \mathrm{O}_{4}$ film, the as-prepared a-Co(OH)$)_{2} / \mathrm{Ti}$ mesh was sintered at $350{ }^{\circ} \mathrm{C}$ for $2 \mathrm{~h}$ with a heating rate of $5{ }^{\circ} \mathrm{C} \mathrm{min}^{-1}$. To prepare $\mathrm{P}-\mathrm{Co}_{3} \mathrm{O}_{4} / \mathrm{Ti}$ samples, the porcelain boats containing $0.1 \mathrm{~g}$ $\mathrm{NaH}_{2} \mathrm{PO}_{2} \cdot \mathrm{H}_{2} \mathrm{O}$ and $\mathrm{Co}_{3} \mathrm{O}_{4} / \mathrm{Ti}$ were placed in the upstream and downstream of the quartz tube, respectively. Subsequently, it was set to $300{ }^{\circ} \mathrm{C}$ for 0.5 hour under $\mathrm{N}_{2}$ atmosphere with the heating rate of $2{ }^{\circ} \mathrm{C} \min ^{-1}$, and then cooled to room temperature naturally. Finally, the $\mathrm{P}-\mathrm{Co}_{3} \mathrm{O}_{4} / \mathrm{NF}$ was obtained. The P-content atomic percentage was obtained from EDS analysis.

\section{Part S5. Preparation of Pd-Cu/Ti and $\mathrm{Cu} / \mathrm{Ti}$ mesh.}

The Pd-Cu/Ti was synthesized by electrodeposition under potentiostatic control. ${ }^{1}$ It was also 
performed in a three-electrode system. Specifically, electrolyte was composed of $2 \mathrm{mM} \mathrm{PdCl}_{2}, 4 \mathrm{mM}$ $157 \mathrm{CuSO}_{4}$ and $0.01 \mathrm{M} \mathrm{HCl}$ and the preparation was conducted at $-1.0 \mathrm{~V}$ vs. SCE. To synthesize $\mathrm{Cu} / \mathrm{Ti}$, the electrolyte comprised of $0.5 \mathrm{M}$ of $\mathrm{CuSO}_{4} \cdot 5 \mathrm{H}_{2} \mathrm{O}$ and given concentration of surfactant, with $\mathrm{pH}$ being adjusted to 2 using $\mathrm{H}_{3} \mathrm{PO}_{4}{ }^{2}$ The preparation was also conducted at $-1.0 \mathrm{~V}$ vs. SCE. After that, the prepared electrodes were washed with deionized water and dried in vacuum. The loading for Pd-Cu and

$\mathrm{Cu}$ on Ti mesh was controlled to be 0.8 and $0.8 \mathrm{mg} \mathrm{cm}^{-2}$.

\section{Part S6. Electrochemical measurements}

The double layer capacitances $\left(\mathrm{C}_{\mathrm{dl}}\right)$ was determined based on $\mathrm{CV}$ test according to Eq. (4).

$$
\frac{I_{a}-I_{c}}{2}=C_{d l} v
$$

where $I_{a}$ and $I_{c}$ represent the measured plateau current, $v$ is the scan rate $\left(\mathrm{V} \mathrm{s}^{-1}\right)$. The electroactive surface area were calculated with the use of electrode geometric surface area $\left(1 \mathrm{~cm}^{2}\right)$ and standard electroactive surface area for standard values $\left(60 \mu \mathrm{F} \mathrm{cm} \mathrm{cm}^{-2}\right){ }^{3}$

\section{Part S7. Analytical Method.}

During the $\mathrm{NO}_{3}{ }^{-}$reduction, the generation of the $\mathrm{NO}$ and $\mathrm{N}_{2} \mathrm{O}$ are negligible and only $\mathrm{N}_{2}$ is the gaseous product. ${ }^{4} \mathrm{UV}$-vis spectrophotometer was used to determine the concentrations of $\mathrm{NO}_{3}^{-}-\mathrm{N}, \mathrm{NO}_{2}^{-}-\mathrm{N}$ and

$\mathrm{NH}_{4}{ }^{+}-\mathrm{N}^{4}$. The concentrations of $\mathrm{Na}^{+}$and $\mathrm{K}^{+}$were measured by inductively coupled plasma optical emission spectrometry (ICP-OES; Agilent 730ES, U.S.A.) with a detection limit of $0.03 \mathrm{mg} \mathrm{L}^{-1}$. The concentrations of $\mathrm{Cl}^{-}$was analyzed via ion chromatography (Dionex ICS-90a, U.S.A.) with a detection 174 limit of $1 \mathrm{mg} \mathrm{L}^{-1}$. The chemical oxygen demand (COD) was measured using the dichromate digestion 175 (Hach Method DRB200) with a detection limit of $3 \mathrm{mg} \mathrm{L}^{-1}$.

Part S8. Nitrogen species interference detection.

All the electrochemical operations were carried out under ambient atmosphere. To evaluate possible 
interferences from any contaminants, we have carefully checked the $\mathrm{N}$ source of the generated $\mathrm{NH}_{3}$. No

$179 \mathrm{NH}_{3}$ could be detected in catholytes at the beginning or ending of electrolysis without $\mathrm{NO}_{3}{ }^{-}$adding or 180 potential applying, confirming that the detected $\mathrm{NH}_{3}$ was produced by the cathode catalyzed 181 electroreduction of $\mathrm{NO}_{3}^{-}$(Supplementary Fig. 42).

\section{Part S9. Calculations of efficiencies.}

The $\mathrm{NO}_{3}^{-}-\mathrm{N}$ removal efficiency, $R_{\mathrm{NO}_{3}^{-}-\mathrm{N}}, \mathrm{NO}_{2}^{-}-\mathrm{N}$ generation efficiency, $S_{\mathrm{NO}_{2}^{-}-\mathrm{N}}, \mathrm{NH}_{4}^{+}-\mathrm{N}$ generation efficiency, $S_{N_{4}^{+}{ }_{-} \text {N }}$, total nitrogen (TN) removal efficiency, $R_{T N}$, and $\mathrm{N}_{2}$ selectivity, $S_{N_{2}}$,

were calculated as followed:

The $\mathrm{NH}_{3}$ recovery efficiency ( $\mathrm{R}_{\text {ammonia }}$ ) was calculated based on the total nitrogen and the generated ammonia:

$$
R_{\text {ammonia }}(\text { based on the total nitrogen })=\frac{\left[\mathrm{NH}_{3} / \mathrm{NH}_{4}^{+}\right] \text {in trap chamber }}{\left[\mathrm{NO}_{3}^{-}\right]_{0}+\left[\mathrm{NO}_{2}^{-}\right]_{0}+\left[\mathrm{NH}_{3} / \mathrm{NH}_{4}^{+}\right]_{0}}
$$

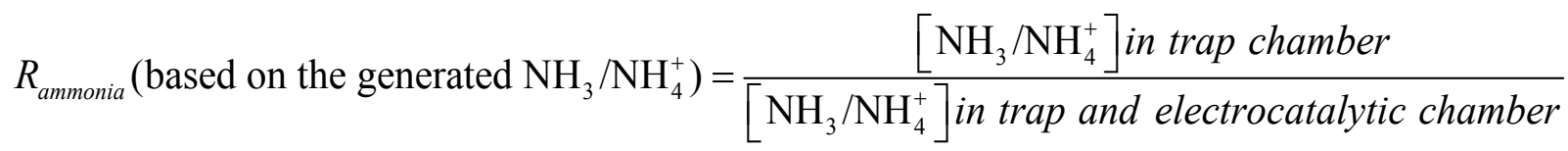

where $\left[\mathrm{NO}_{3}{ }^{-}-\mathrm{N}\right]_{0}$ is the initial concentration of $\mathrm{NO}_{3}{ }^{-}-\mathrm{N} .\left[\mathrm{NO}_{3}{ }^{-}-\mathrm{N}\right]_{\mathrm{t}},\left[\mathrm{NO}_{2}{ }^{-}-\mathrm{N}\right]_{\mathrm{t}}$ and $\left[\mathrm{NH}_{4}{ }^{+}-\mathrm{N}\right]_{\mathrm{t}}$ are the concentrations of $\mathrm{NO}_{3}^{-}-\mathrm{N}, \mathrm{NO}_{2}^{-}-\mathrm{N}$ and $\mathrm{NH}_{4}{ }^{+}-\mathrm{N}$ at time $\mathrm{t}$.

\section{Part S10. Calculations of Faraday efficiency and energy consumption.}

The ENRRA process consists of nitrate reduction to ammonia and ammonia recovery. Since the 
199 ammonia recovery process is driven by the strong alkaline environment of the cathode surface and 200 electrolyte, which accompanied by no charge transfer. This process cannot be included in the Faraday 201 efficiency calculation. Therefore, Faraday efficiency (FE) for electrocatalytic nitrate reduction to 202 ammonia was calculated based on the nitrate reduction and selectivity towards ammonia. Considering 203 that this process is basically completed within the first half of the overall reaction. Thus, the FE of 204 electrocatalytic nitrate reduction to ammonia calculation is based on the charge transfer amount of the 205 period when the nitrate concentration drops below one-tenth of the initial concentration (an order of magnitude reduction). The calculation of other parameters is all based on the overall reaction process.

The performances of series parameters on the $\mathrm{NO}_{3}{ }^{-}$removal and $\mathrm{NH}_{3}$ recovery efficiency compared to total N-containing $\left(\mathrm{R}_{\text {nitrate, }}, \mathrm{R}_{\text {ammonia }}\right)$, FE of electrocatalytic $\mathrm{NO}_{3}{ }^{-}$reduction to ammonia, partial current

density toward ammonia $\left(\mathrm{j}_{\mathrm{NH} 3}\right)$, energy consumption (EC) for $\mathrm{NO}_{3}{ }^{-}$reduction and $\mathrm{NH}_{3}$ recovery, $\mathrm{NH}_{3} / \mathrm{NH}_{4}{ }^{+}$recovery efficiency rate and initial $\mathrm{NO}_{3}{ }^{-}$reduction rate were investigated in $0.1 \mathrm{M} \mathrm{Na}_{2} \mathrm{SO}_{4}$ containing $10 \mathrm{mM} \mathrm{NO}_{3}{ }^{-}\left(25-100 \mathrm{mM}^{-1} \mathrm{NO}_{3}{ }^{-}\right.$concentration investigation).

$$
F E(\%)=\frac{n \times F \times N_{i}}{Q} \times 100
$$

where $\mathrm{n}=8$ for nitrate to $\mathrm{NH}_{3} ; \mathrm{F}$ is the Faraday constant $\left(96487 \mathrm{C} \mathrm{mol}^{-1}\right)$; $\mathrm{N}_{\mathrm{i}}$ is the amount (mol) of product generated during the electrolysis; Q (C) is the total charge passing the electrode; Q was calculated based on the integration of the curve I vs $t$; $I \times t$ is approximately regard as the integral area under the curve I vs $t$, I (A) is the measured average electric current $(0 \mathrm{~s}$ to the time when the nitrate concentration drops below one-tenth of the initial concentration), $\mathrm{t}(\mathrm{s})$ is the time when the nitrate concentration drops below one-tenth of the initial concentration. 
where $\mathrm{U}$ is total cell potential $(\mathrm{V}), \mathrm{I} \times \mathrm{t}$ is the integral area under the curve $\mathrm{I} v \mathrm{vs}(\mathrm{Ah})$, and $\mathrm{m}$ is mass

223 of the removed target $(\mathrm{Kg})$.

ENRRA rate $\left(\mathrm{g}-\mathrm{N} \mathrm{m} \mathrm{m}^{-2} \mathrm{~d}^{-1}\right)$ was calculated based on the ammonia/ammonium recovery amount in

trap chamber, reactive electrode area, and overall reaction time.

\section{Part S11. Interfacial pH calculation}

The cathodic reaction causes an increasing $\mathrm{pH}$ gradient toward the electrode surface, thus $\mathrm{pH}^{*} \geq$

$\mathrm{pH}^{\mathrm{b}}$. The transport fluxes of $\mathrm{H}^{+}$and $\mathrm{OH}^{-}$, expressed as currents, can be derived from the Fick's law and are shown as below:

$$
\mathrm{j}=\left(1000 \mathrm{Fm}_{\mathrm{H}} 10^{-\mathrm{pHb}}\right) \times\left(1-10^{\mathrm{pHb}-\mathrm{pH} *}\right)+\left(1000 \mathrm{Fm}_{\mathrm{OH}} 10^{\mathrm{pHb}-\mathrm{pKw}}\right) \times\left(10^{\mathrm{pH} *-\mathrm{pHb}}-1\right)
$$

where $\mathrm{pH}^{*}$ and $\mathrm{pH}^{\mathrm{b}}$ are the interfacial $\mathrm{pH}$ and bulk solution $\mathrm{pH}, \mathrm{p}_{\mathrm{Kw}}$ is the logarithm of the ionization constant of water. $\mathrm{j}$ is the overall transport current $\left(\mathrm{A} / \mathrm{m}^{2}\right) . \mathrm{m}_{\mathrm{OH}}=\mathrm{D}_{\mathrm{OH}} / \delta_{\mathrm{N}}(\mathrm{m} / \mathrm{s}), \mathrm{m}_{\mathrm{H}}=\mathrm{D}_{\mathrm{H}} / \delta_{\mathrm{N}}(\mathrm{m} / \mathrm{s}), \mathrm{D}_{\mathrm{OH}}$ and $\mathrm{D}_{\mathrm{H}}$ are the diffusion coefficients of $\mathrm{OH}^{-}$and $\mathrm{H}^{+}\left(\mathrm{m}^{2} / \mathrm{s}\right)$. The diffusion layer thickness $\left(\delta_{N}\right)$ of $\mathrm{OH}^{-}$and

$\mathrm{H}^{+}$are selected as 21.5 and $24.5 \mu \mathrm{m}$ according to previous study (calculated by Levich equation) ${ }^{5}$.

\section{Part S12. IR compensation}

Solution resistance causes a voltage drop between the reference electrode and the working electrode

which follows Ohm's law: $\mathrm{V}=\mathrm{I} \times \mathrm{R} .6,7$ This resistance is commonly referred to as uncompensated

resistance $\left(\mathrm{R}_{\mathrm{u}}\right)$ because the potentiometric operation does not compensate for it under normal conditions.

$\mathrm{R}_{\mathrm{u}}$ is dependent upon a number of factors, such as electrolyte, temperature, electrode placement, and

electrode size. Since $\mathrm{R}_{\mathrm{u}}$ may differ between various experiments, it must be corrected in order to generate consistent data. This is particularly important when comparing data between different laboratories where different experimental setups are used or when comparing to theoretical predictions. 
In this study, electrochemical impedance spectroscopy (EIS) was used to determine $\mathrm{R}_{\mathrm{u}}$. All

electrolysis was performed using an electrochemical workstation (PGSTAT 302N, Metrohm) with a

saturated SCE reference. Electrode potentials were rescaled to SHE referenced by $\mathrm{E}_{\mathrm{SHE}}=\mathrm{E}_{\mathrm{SCE}}+0.241$

$\mathrm{V}$. The relationship between an AC potential and the resulting AC current defines the impedance. ${ }^{8}$ At

high frequency, contributions to the impedance from components of the electrochemical circuit other than

$\mathrm{R}_{\mathrm{u}}$ become negligible. However, there is a limit to how high of frequency can be used before the measured impedance no longer applies to the electrochemical cell. To find the correct frequency in determining $\mathrm{R}_{\mathrm{u}}$,

EIS was performed at frequencies ranging from $0.1 \mathrm{MHz}$ to $0.1 \mathrm{~Hz}$ at open circuit potential. $10 \mathrm{kHz}$

frequency by a potential amplitude of $50 \mathrm{mV}$ was chosen as an appropriate frequency to determine $\mathrm{R}_{\mathrm{u}}$,

which corresponds to the real impedance measured at this frequency.

To get the most accurate numbers, the ohmic drops between the working and reference electrodes

was mathematically corrected for after the electrochemical data was collected. Electrode potentials after

iR compensation were rescaled to SHE referenced according to: $\mathrm{V}_{100 \% \text { IR corrected vs. SHE }}=\mathrm{V}_{\mathrm{SCE}}+0.241 \mathrm{~V}-$ average $\mathrm{R}_{\mathrm{u}}(\mathrm{Ohms}) \times$ average I (amps).

\section{Part S13. DFT calculations.}

The first-principles calculations in the framework of the spin-polarized density functional theory (DFT) were performed based on the Vienna ab initio Simulation Package (VASP) ${ }^{9}$. The exchange correlation functional under the generalized gradient approximation with projector augmented wave pseudo-potentials and the Perdew-Burke-Ernzerhof functional was adopted to describe the electronelectron interaction in CoP systems with an energy cutoff of $450 \mathrm{eV}^{10}$. a MonkhorstPack mesh k-point sampling set of $7 \times 7 \times 7$ was used for the bulk CoP calculation, and the optimized lattice parameters of 
$2653.28 \AA \times 5.59 \AA)$ and previous theoretical results $(5.08 \AA \times 3.27 \AA \times 5.54 \AA)$. The gamma k-point 266 was applied for the calculations on the (211) surface of CoP with the size of $12.89 \AA \times 16.40 \AA \times 20$ $267 \AA$, while the vacuum space in the direction perpendicular to the (211) surfaces was kept to $>12 \AA$. The 268 DFT-D3 method was used for describing the long-range dispersion interaction, and all the atomic 269 positions were fully relaxed until the final energy and force on each atom were less than $10^{-5} \mathrm{eV}$ and 0.02 $270 \mathrm{eV} / \AA \AA$, respectively. Besides, to quantify the amount of charge transferred between $\mathrm{NO}_{3}{ }^{-}$and $\mathrm{CoP}$, the 271 Bader charges for the intrinsic and composite surface and $\mathrm{NO}_{3}{ }^{-}$were also calculated ${ }^{11}$. In reaction pathway calculations, the concept of computational hydrogen electrode was applied, so the chemical potential of the $\mathrm{H}^{+}+\mathrm{e}^{-}$can be referenced by half of the chemical potential of $\mathrm{H}_{2}$ at $0 \mathrm{~V}$.

Then the change of free energy of intermediates on the CoP (211) surface was calculated by:

$$
\Delta \mathrm{G}=G_{* A}-G_{*}-G_{A}
$$

where $G_{* A}, G_{*}$ and $G_{A}$ denote the total free energy of the adsorbed system, the clear surface and

adsorbates, respectively. The Gibbs free energy was estimated under zero potential by:

$$
\mathrm{G}=\mathrm{E}+Z P E-T S
$$

is the reaction temperature which was considered as $300 \mathrm{~K}$ here, and $\mathrm{S}$ denotes the entropy.

Three finial products $\left(\mathrm{N}_{2}, \mathrm{NO}_{2}^{-}, \mathrm{NH}_{3}\right)$ were chosen based on our actual $\mathrm{N}$-containing species detections and experiments. To obtain the rationale reaction pathways and clarify the mechanism from $\mathrm{NO}_{3}{ }^{-}$to $\mathrm{N}_{2}, \mathrm{NO}_{2}{ }^{-}, \mathrm{NH}_{3}$, each possible intermediate was built and optimized according to element characteristics, interface conditions and the stable configuration of its previous product. For example, the $* \mathrm{NO}_{2} \mathrm{OH}$ was formed by adding a proton $\left(\mathrm{H}^{+}+\mathrm{e}^{-}\right)$on the most stable configuration of $* \mathrm{NO}_{3}$ (as shown in Figure S39 and Table S4). And the position of proton defaults to be close to the oxygen atom with the 
a. The electronegativity of oxygen and nitrogen is 3.5 and 3, respectively. The higher electronegativity of oxygen makes it easier to obtain the electrons from electrode and then combine with $\mathrm{H}^{+}$to form a "-OH" group.

b. The lowest coordination number means such atoms are more likely to contact with proton to achieve a more stable state.

c. The atoms far away from the catalytic surface are more likely to be in contact with $\mathrm{H}^{+}$in in the solution and become a proton addition site.

According to the above principle of hydrogenation and reduction and ensuring the latter intermediate had a similar atomic layout with the previous one to avoid a large energy barrier, the reaction pathways of $\mathrm{NO}_{2}{ }^{-}$and $\mathrm{NH}_{3}$ were established and shown in Figure $\mathrm{S} 48-49$.

It can be seen that the $\mathrm{NH}_{3}$ formation pathway diverged at $* \mathrm{NOOH}$. We compared the formation energies of the two intermediates $\left({ }^{*} \mathrm{NOHOH}\right.$ and $\left.{ }^{*} \mathrm{NO}\right)$ and found that the latter one was easier to generate with a $0.6 \mathrm{eV}$ gap (Table S8), as shown below. Thus, the $\mathrm{NO}_{3}{ }^{-} \rightarrow * \mathrm{NO} \rightarrow \mathrm{NH}_{3}$ pathway was chosen in Figure 4f.

The generation of $\mathrm{N}_{2}$ is more complicated than $\mathrm{NO}_{2}{ }^{-}$and $\mathrm{NH}_{3}$ because it requires the combination of two nitrogen species (Figure S50). Since the directly combination of two adjacent adsorbed mononitrogen species is blocked by the large adjacent distance (Figure S44), a dissociated mono-nitrogen species is necessary for $\mathrm{N}_{2}$ formation. According to the experimental results of Huo et. al. ${ }^{12} \mathrm{NO}_{2}{ }^{-}$is the key reactant, and the reaction pathways of $\mathrm{N}_{2}$ are established and shown below.

We have tested all possible combinations of adsorbed mono-nitrogen intermediate and $\mathrm{NO}_{2}{ }^{-}(\mathrm{Table}$ S6). The results show that $* \mathrm{~N}_{2} \mathrm{O}_{4}$ and $* \mathrm{~N}_{2} \mathrm{O}_{3} \mathrm{OH}$ cannot exist stably, and the combinations of $* \mathrm{NOH}(2.49$ $\mathrm{eV}),{ }^{*} \mathrm{~N}(2.90 \mathrm{eV}),{ }^{*} \mathrm{NH}(2.95 \mathrm{eV})$, and $* \mathrm{NH}_{2}(3.68 \mathrm{eV})$ consumes more energy than $* \mathrm{NO}(2.28 \mathrm{eV})$, as shown in Table S6. Thus, the pathway of $\mathrm{NO}_{3}{ }^{-} \rightarrow * \mathrm{NO} \rightarrow \mathrm{N}_{2} \mathrm{O}_{3} \rightarrow \mathrm{N}_{2}$ was chosen in Figure $4 \mathrm{f}$.

The similar pathway was also accepted by various previous studies. ${ }^{12-14}$

\section{Part S14. Normalized peak current density calculations.}

$$
\text { Normalized value }=\frac{\text { Value of peak current density }}{\text { The highest value of peak current density }}
$$

$$
\text { Normalized value }=\frac{\text { Value of reciprocal of Tafel slope }}{\text { The highest value of reciprocal of Tafel slope }}
$$


Part S15. Co leaching test.

The leaching of $\mathrm{Co}$ ions from all the four Co-based cathodes $\left(\mathrm{P}-\mathrm{Co}_{3} \mathrm{O}_{4}, \mathrm{CoP}, \mathrm{OP}-\mathrm{CoP}, \mathrm{Co}_{3} \mathrm{O}_{4}\right)$ to the 317 solution after $3 \mathrm{~h}$ nitrate reduction experiments were tested. The concentration of Co ion was measured 318 via ICP-MS (Agilent 7700) with the detection limit of $1 \mu \mathrm{g} \mathrm{L}^{-1}$. The leaching concentration of Co ions of $319 \mathrm{Co}_{3} \mathrm{O}_{4}$ cathode was the highest $\left(0.05 \mathrm{mg} \mathrm{L}^{-1}\right)$. The leaching concentration of other Co-based cathodes 320 were all lower than or close to $0.01 \mathrm{mg} \mathrm{L}^{-1}$. Thus, the leaching concentration of Co ions of all Co-based cathodes are significantly lower than the regulation of GB/T 25467-2010 in China (1.0 $\mathrm{mg} \mathrm{L}^{-1}$ cobalt ions). 


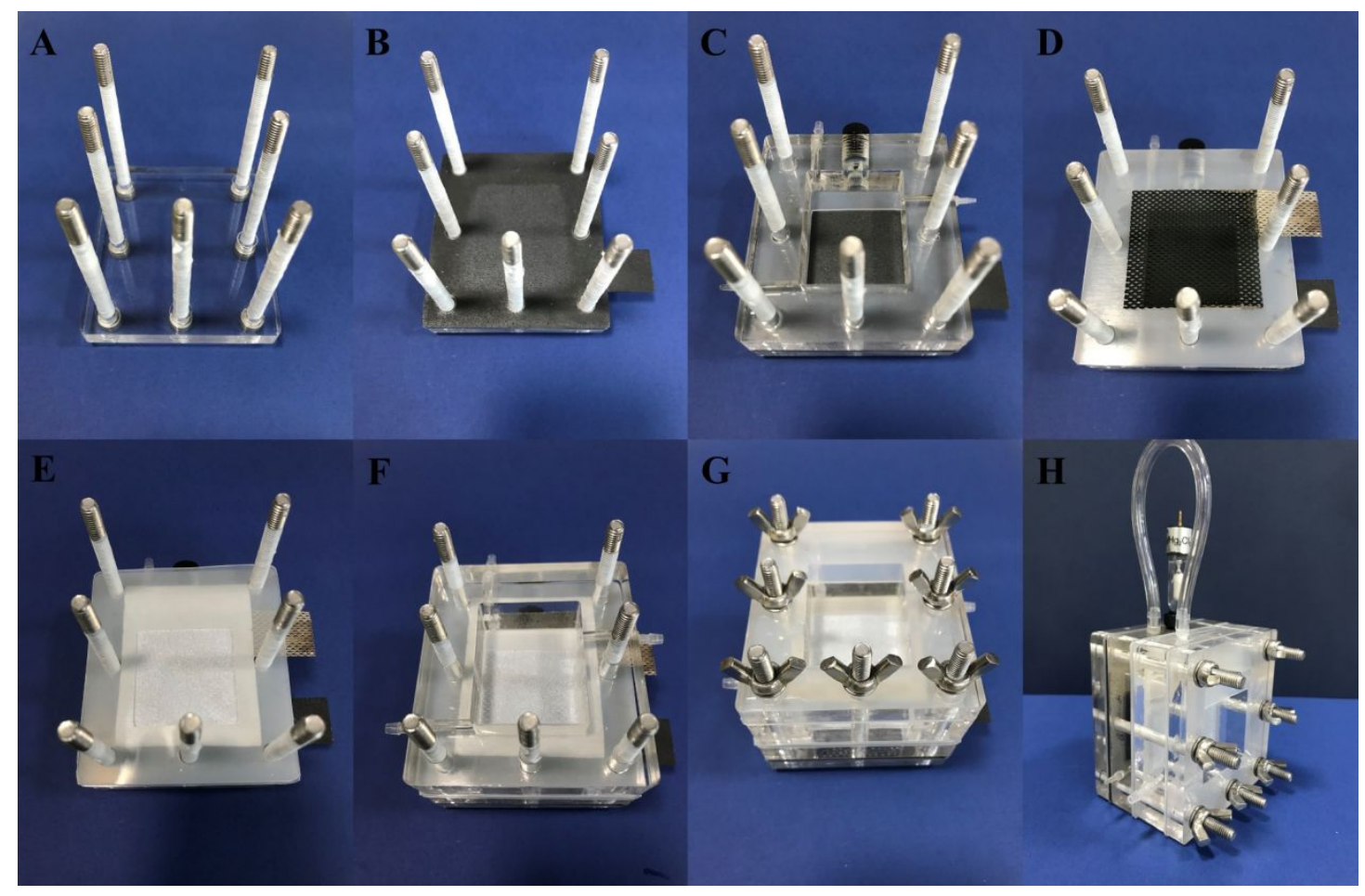

323 Figure S1. Schematic diagram of ENRRA reaction. The plastic tube in Figure $\mathrm{H}$ is a gas tube to collect 324 the ammonia stripping from the electrolytic chamber. 


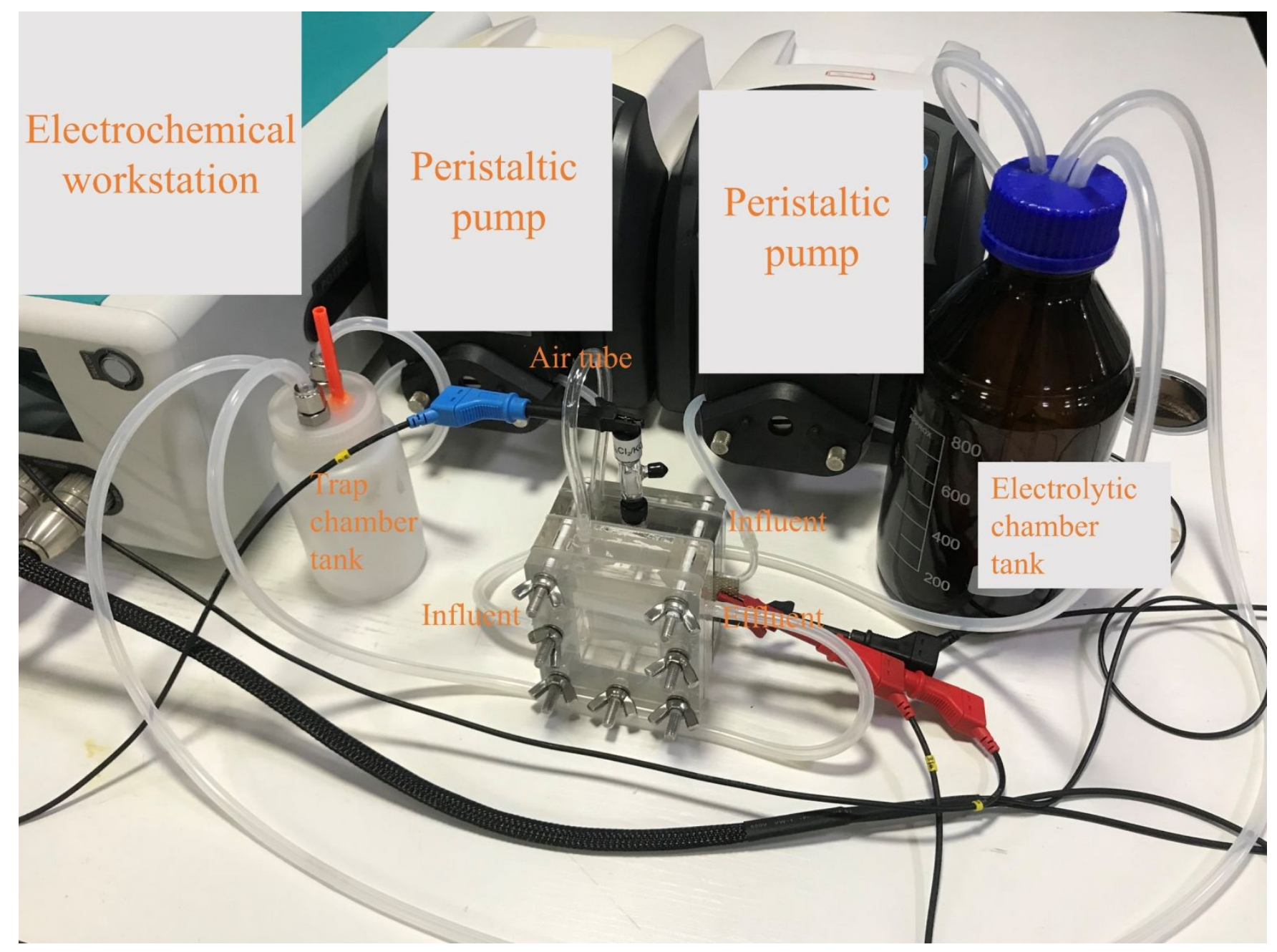

326 Figure S2. Figure of system construction. 


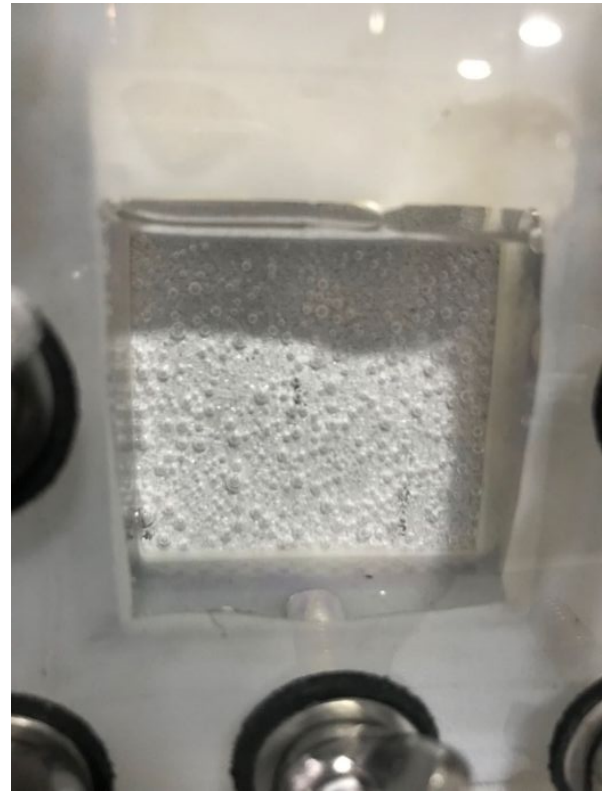

328 Figure S3. ENRRA reactor in working condition. The bubbles on the FGM clearly show the migration of 329 gas from the electrolytic chamber to the trap chamber. 


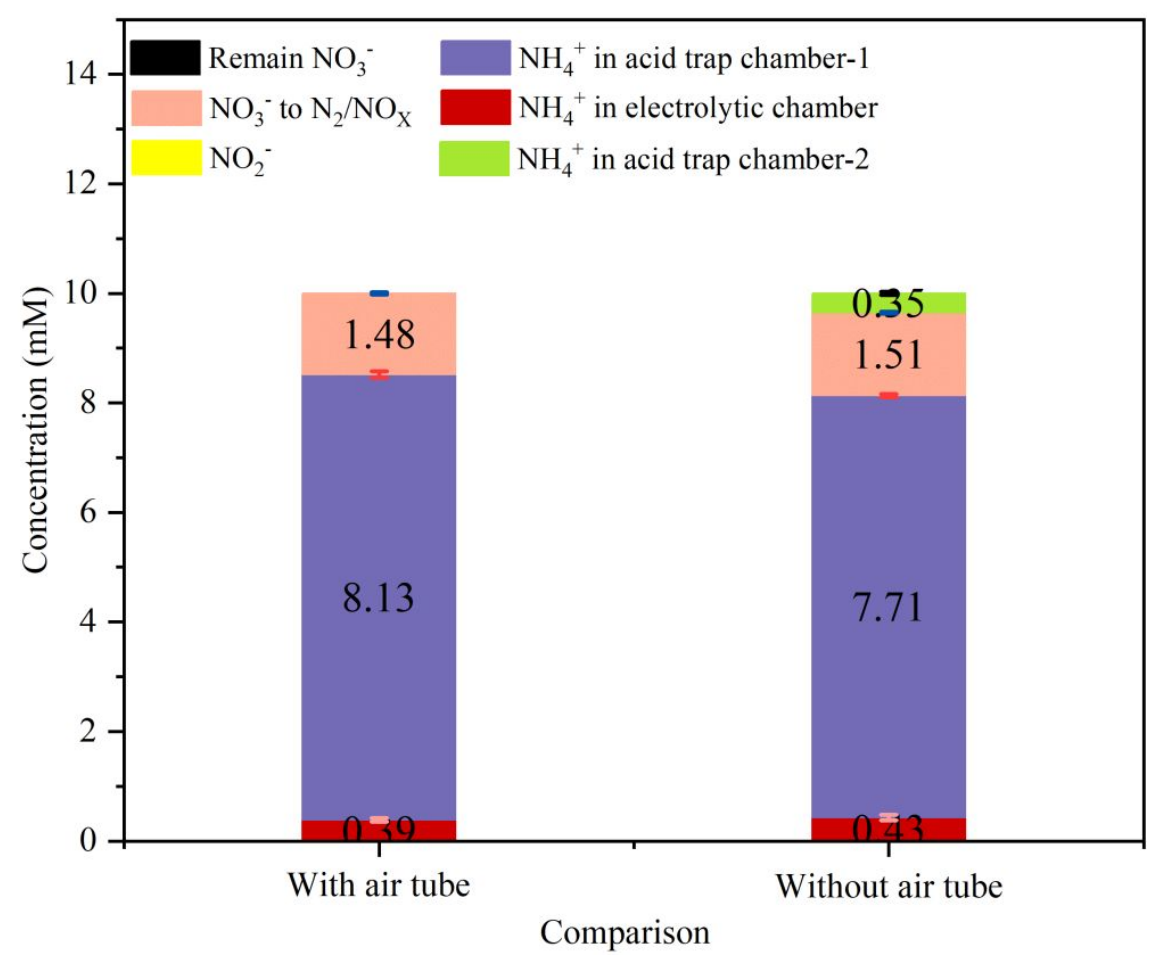

331 Figure S4. Ammonia recovery comparation with and without gas tube. In most experiments (left, with air 332 tube), the gas tube was used to connect the electrolytic chamber (represented by red in the picture) and 333 acid trap chamber-1 represented by purple in the picture). However, the recovered $\mathrm{NH}_{3}$ via the gas membrane was also trapped in the acid trap chamber-1. In order to measure the $\mathrm{NH}_{3}$ recovery amount via 335 the gas tube, the gas tube was used to connect the electrolytic chamber and acid trap chamber-2 336 (represented by green in the picture) (right, without air tube). Thus, the $\mathrm{NH}_{3} / \mathrm{NH}_{4}{ }^{+}$marked in green 337 represents the amount of $\mathrm{NH}_{3} / \mathrm{NH}_{4}{ }^{+}$recovered via gas tube. Basic testing conditions: aqueous solution 338 volume, $100 \mathrm{~mL}$ of $\mathrm{NO}_{3}{ }^{-}$containing wastewater recycling in reactor chamber, $100 \mathrm{~mL}$ of $1 \mathrm{M} \mathrm{H}_{2} \mathrm{SO}_{4}$ 339 recycling in recovery chamber; $\mathrm{Na}_{2} \mathrm{SO}_{4}$ concentration, $0.1 \mathrm{M}$; cathode size in reaction, $16 \mathrm{~cm}^{2}, \mathrm{CoP}$ 340 cathode; catalyst dosage, $0.8 \mathrm{mg} \mathrm{cm}{ }^{-2} \times 16 \mathrm{~cm}^{2}=12.8 \mathrm{mg}$; anode size in reaction, $16 \mathrm{~cm}^{2}, \mathrm{IrO}_{2}-\mathrm{RuO}_{2} / \mathrm{Ti}_{\text {; }}$ 341 electrode gap, $2.0 \mathrm{~cm}$; reference electrode, $\mathrm{SCE}$; temperature, $\sim 25{ }^{\circ} \mathrm{C}$; circulation flow rate, $100 \mathrm{~mL}$ $342 \mathrm{~min}^{-1}$; reaction time, $3.0 \mathrm{~h}$. Specific testing conditions: $\mathrm{NO}_{3}{ }^{-}$concentration, $10 \mathrm{mM} ; \mathrm{pH}, \sim 7.0 ; \mathrm{Cl}^{-}, 0 \mathrm{mg}$ $343 \quad \mathrm{~L}^{-1}, \mathrm{FGM}, 0.45 \mu \mathrm{m}$; applied potential, $-2.4 \mathrm{~V}$ versus SHE without IR correction. 


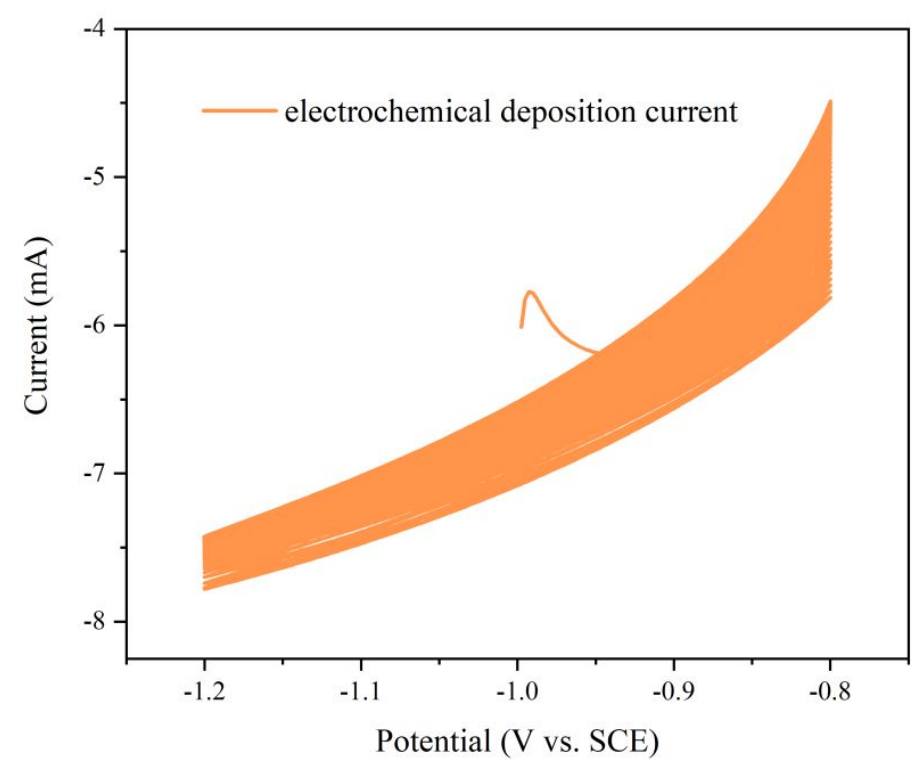

345 Figure S5. Typical response current curve of $\mathrm{Co}(\mathrm{OH})_{2}$ nanosheet array prepared by cyclic voltammetry 346 electrodeposition. -0.8 to $-1.2 \mathrm{~V}$ vs. SCE are selected as the potential interval. In this potential range, 347 almost no bubbles can be observed on the cathode surface during the electrodeposition process, which is 348 conducive to the formation of a good nanosheet array structure. In a typical CV electrodeposition 349 experiment, the response current circulates between -4 to $-8 \mathrm{~mA}$, which has good repeatability. This helps 350 to obtain cobalt hydroxide precursor with approximate loading quality during the preparation of different 351 electrodes. 


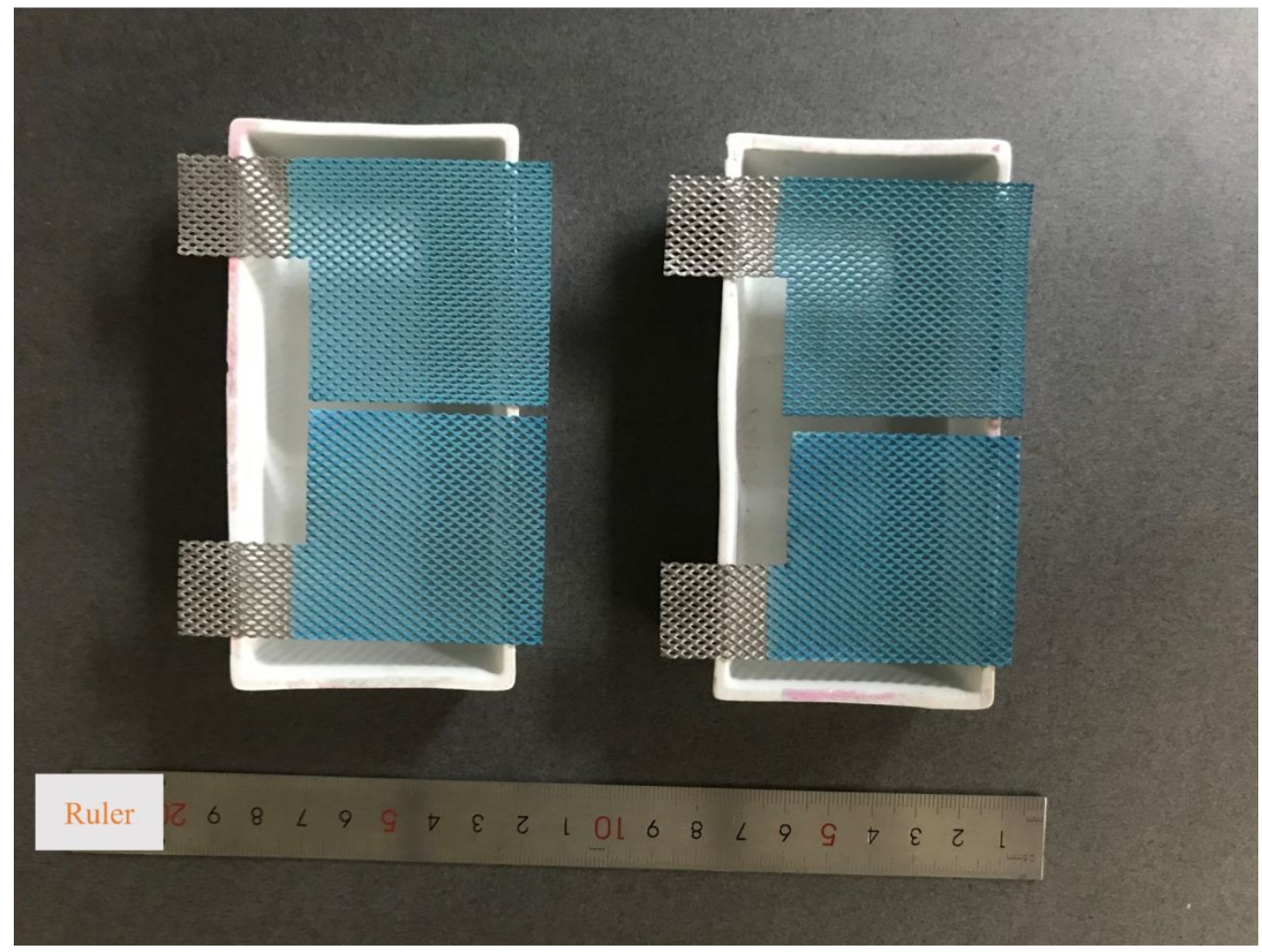

353 Figure S6. The physical images of self-supported cobalt hydroxide precursors. The repeatability and 354 uniformity of the CV electrodeposition process is stable. This ensures the stability of the preparation of a 355 series of cobalt-based cathodes using the precursor, and reduces the experimental error caused by the 356 difference of the precursor between different cathodes. 


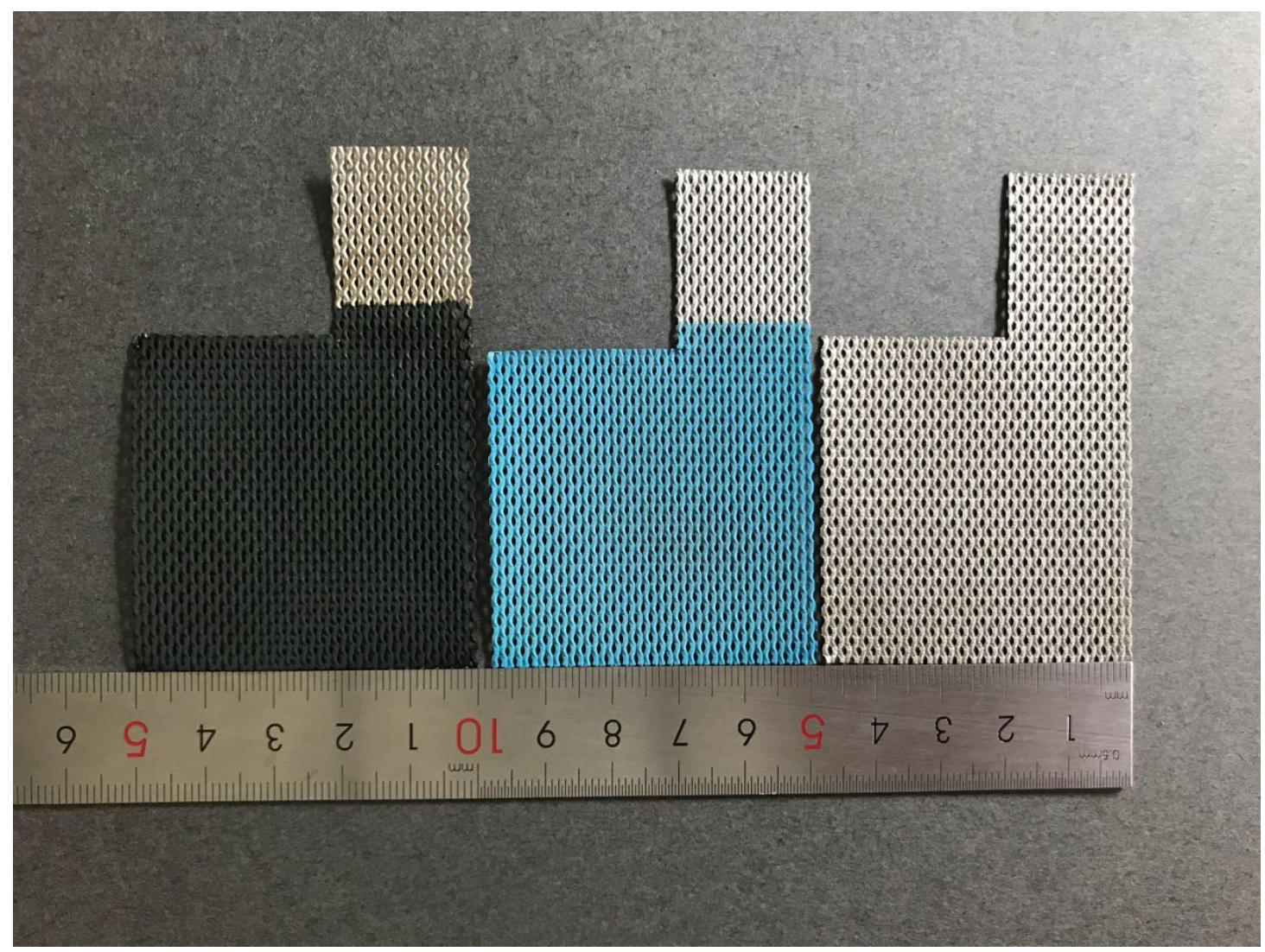

358 Figure S7. The physical images of $\mathrm{CoP}, \mathrm{Co}(\mathrm{OH})_{2}$, and Ti mesh (left to right). The morphologies of $\mathrm{Co}_{3} \mathrm{O}_{4}$

$359 \mathrm{P}-\mathrm{Co}_{3} \mathrm{O}_{4}$ and over phosphatized $\mathrm{CoP}$ are similar to $\mathrm{CoP}$, and all are uniform black catalytic layers. 


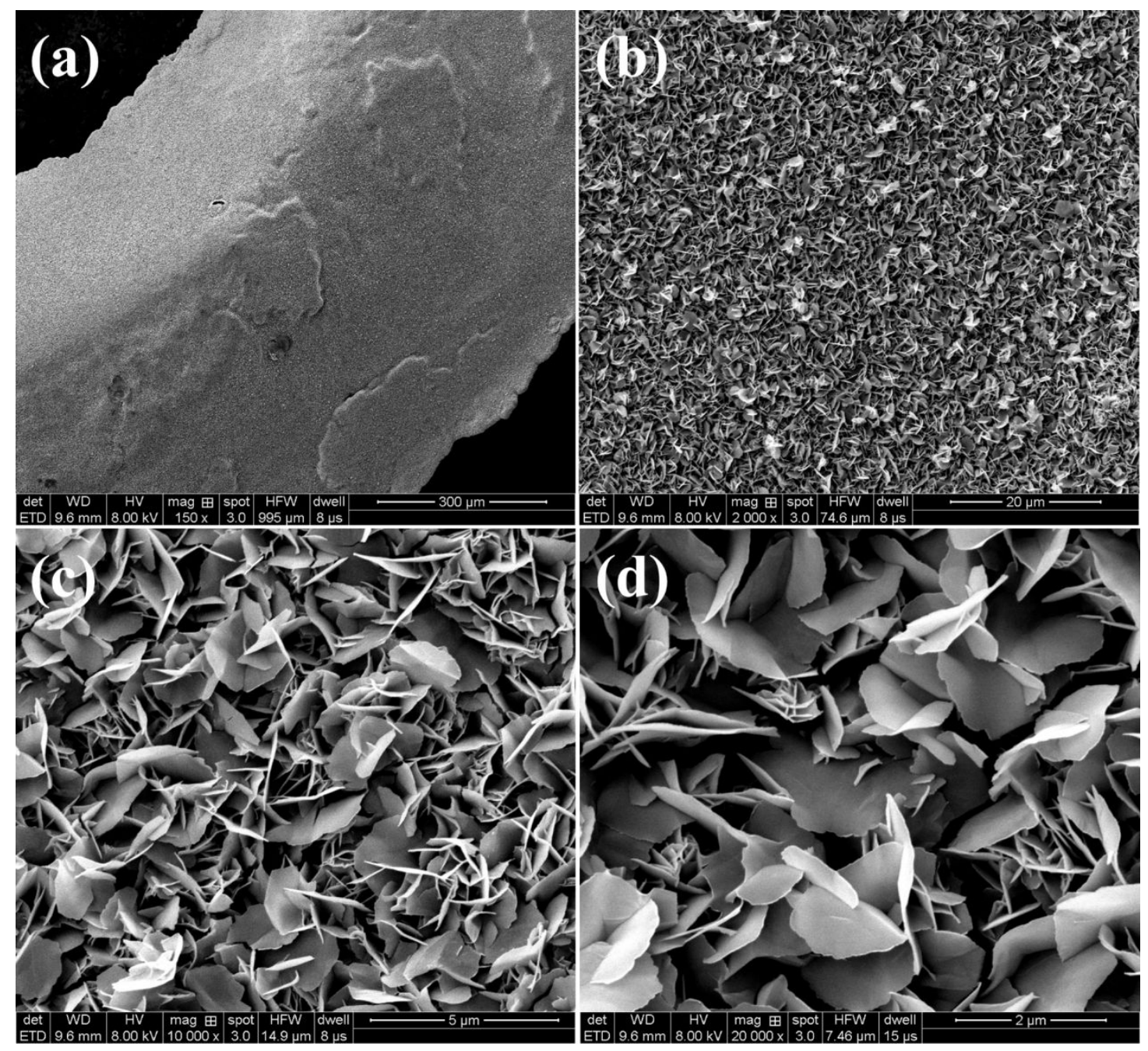

361 Figure S8. SEM images of $\mathrm{Co}(\mathrm{OH})_{2}$. 

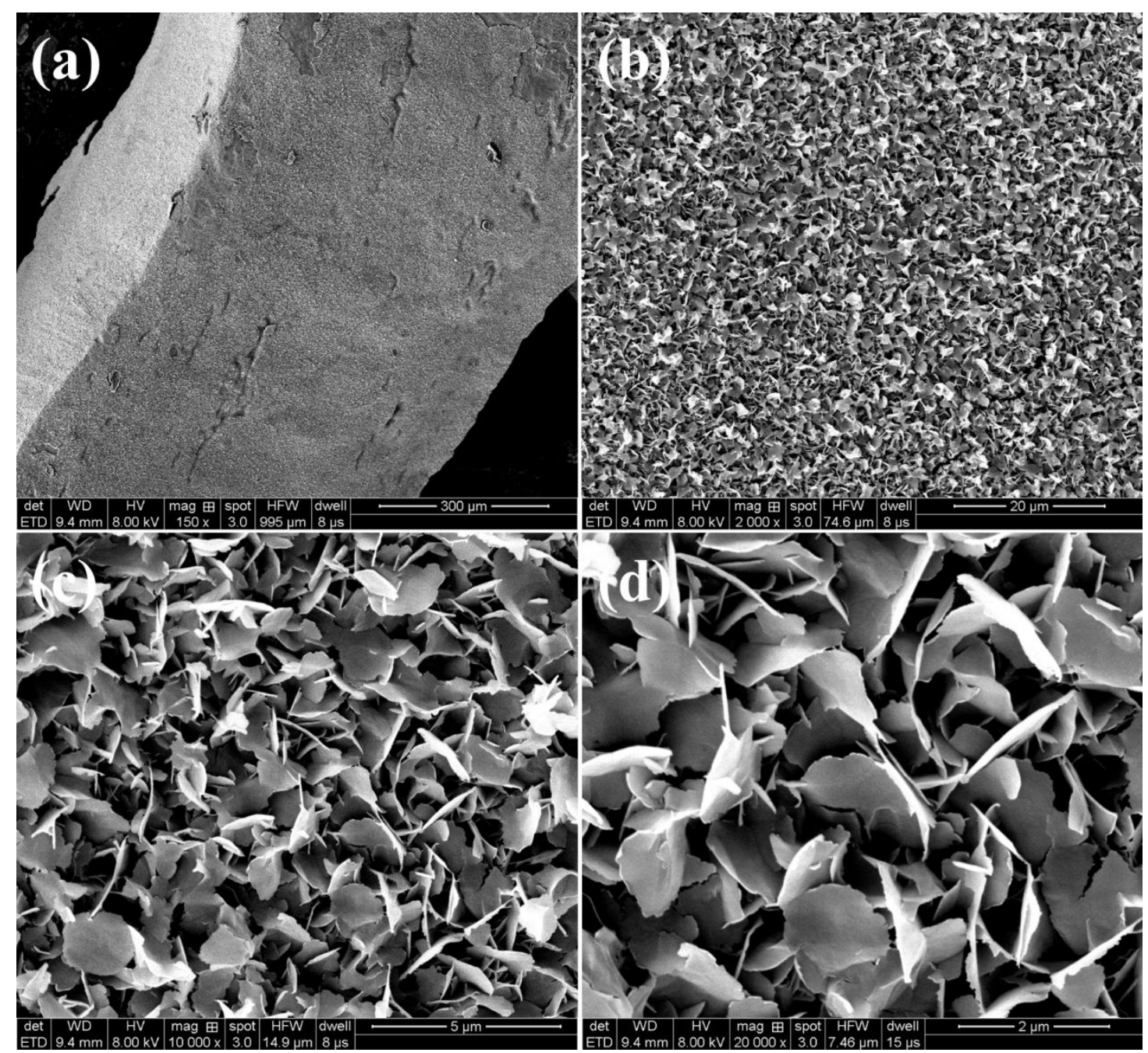

Figure S9. SEM images of $\mathrm{Co}_{3} \mathrm{O}_{4}$. 

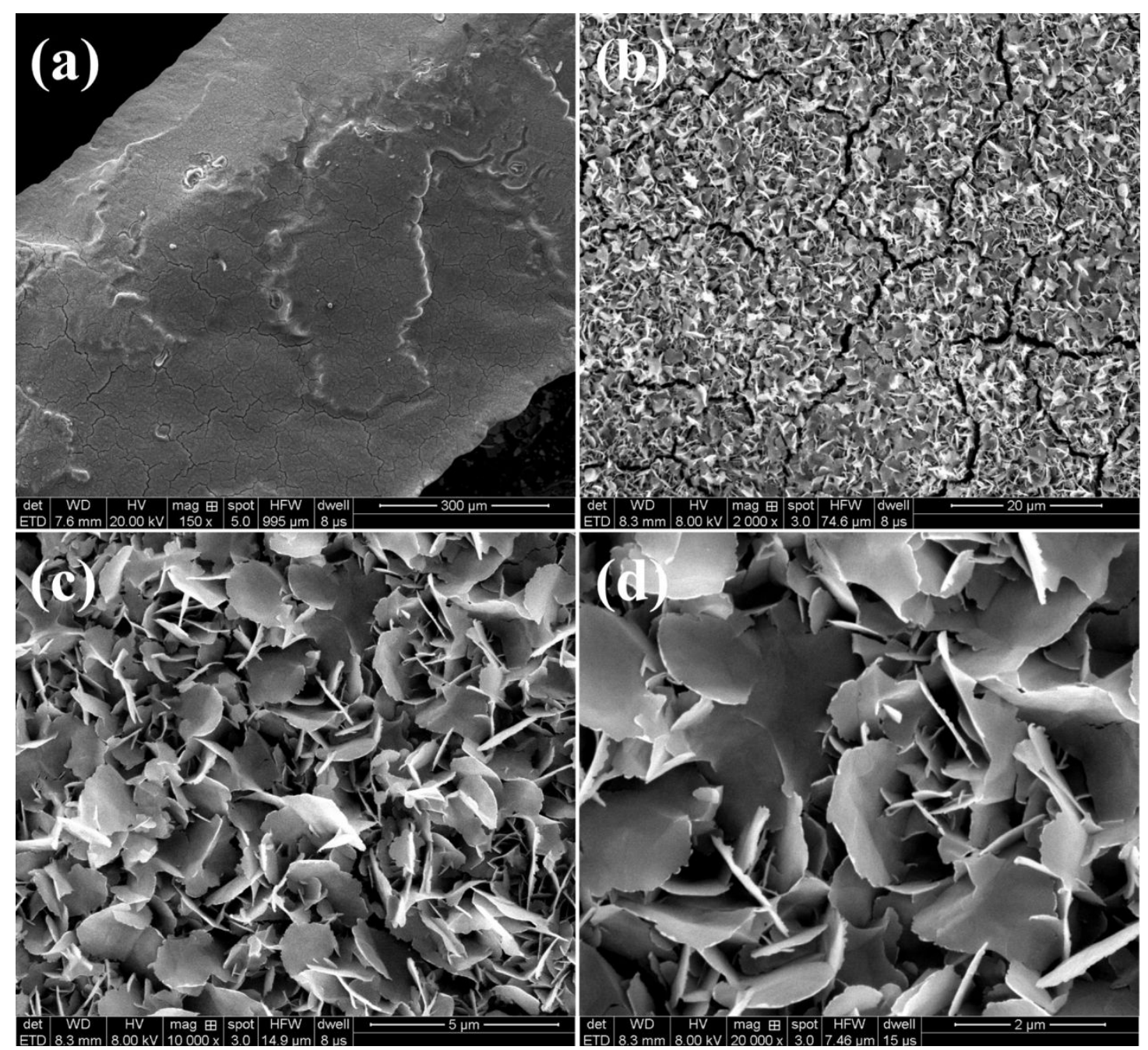

365 Figure S10. SEM images of $\mathrm{P}-\mathrm{Co}_{3} \mathrm{O}_{4}$. 

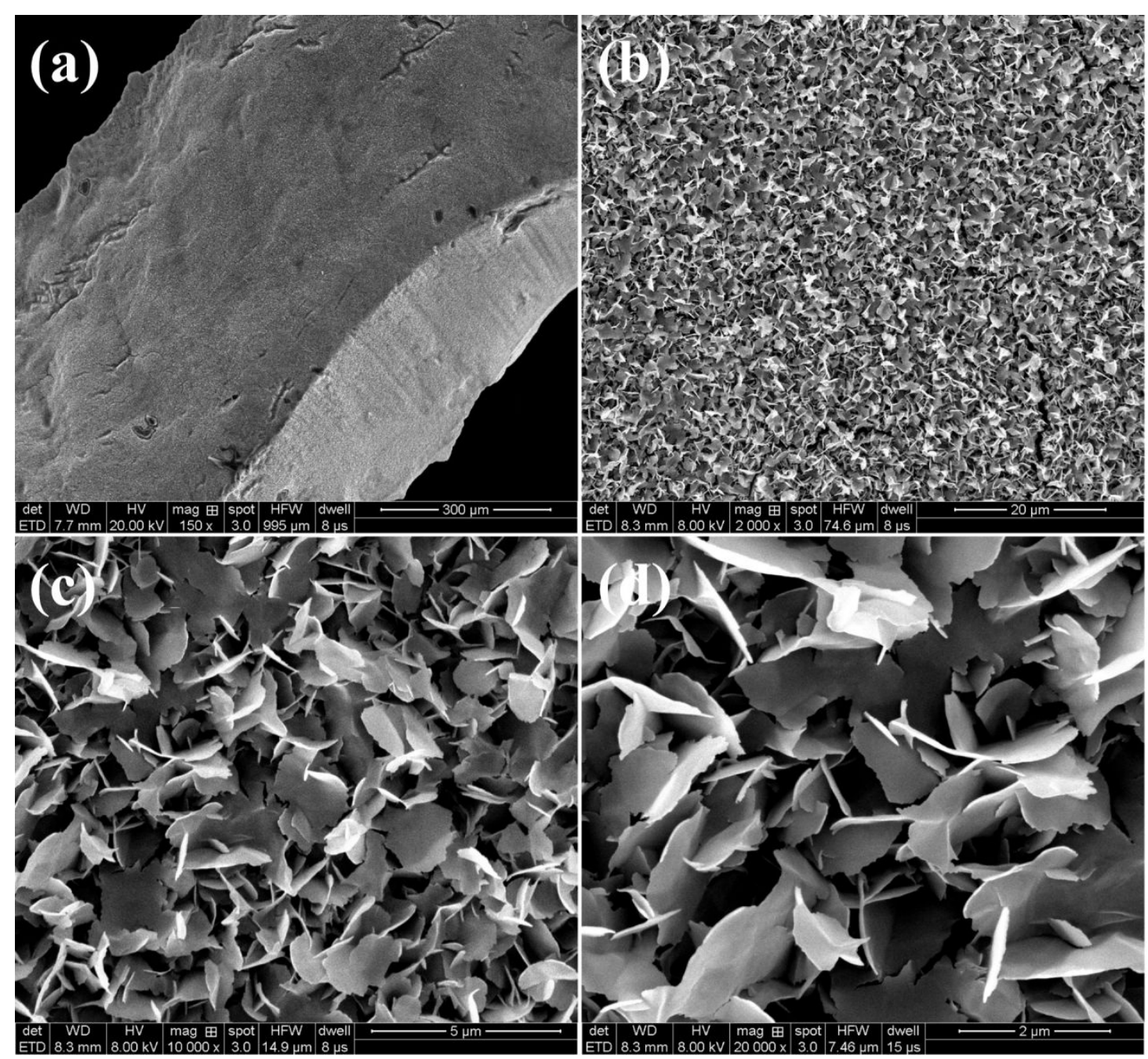

367 Figure S11. SEM images of CoP. 


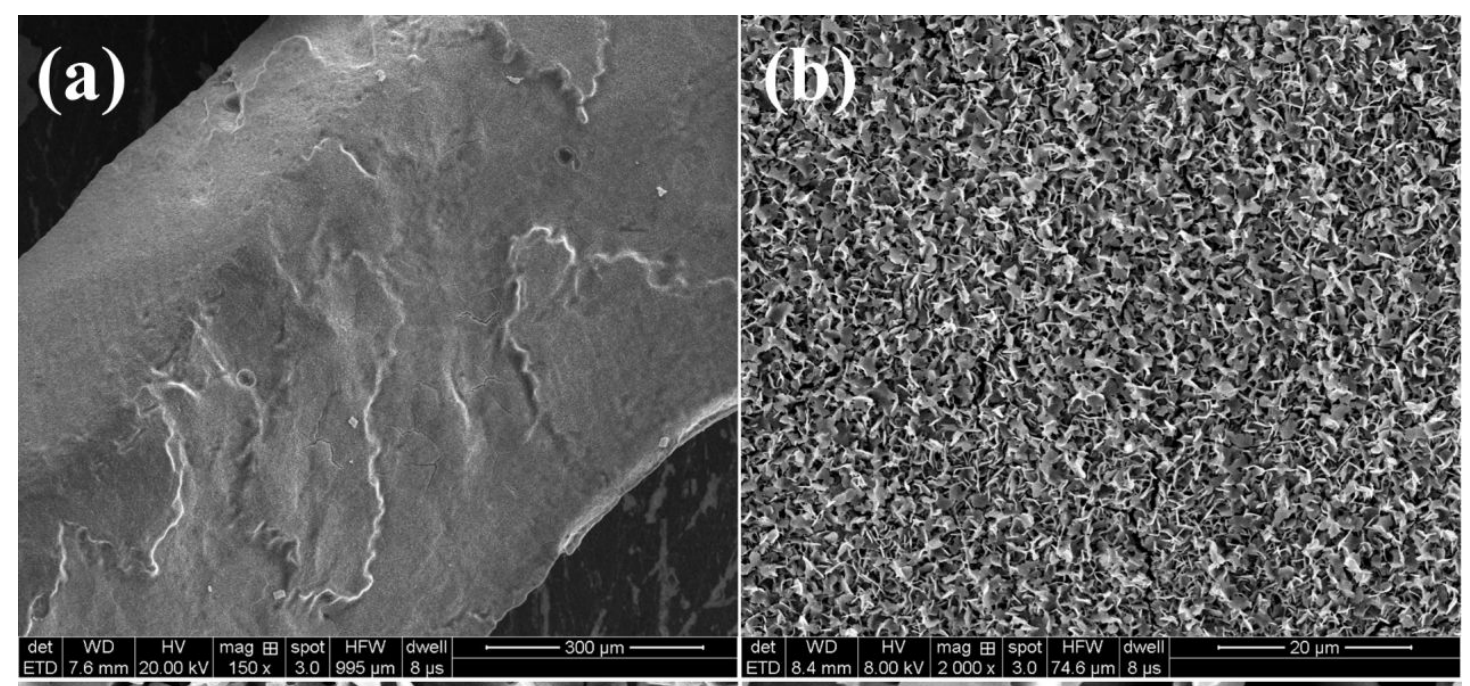

Figure S12. SEM images of over phosphatized CoP. It can be seen that, compared with the SEM images

370 of the above four materials, the thickness of over phosphatized CoP nanosheet has increased, and many

371 holes have appeared. It is speculated that this is due to the corrosive effect of a large amount of $\mathrm{PH}_{3}$

372 produced by a large amount of sodium hypophosphite. 


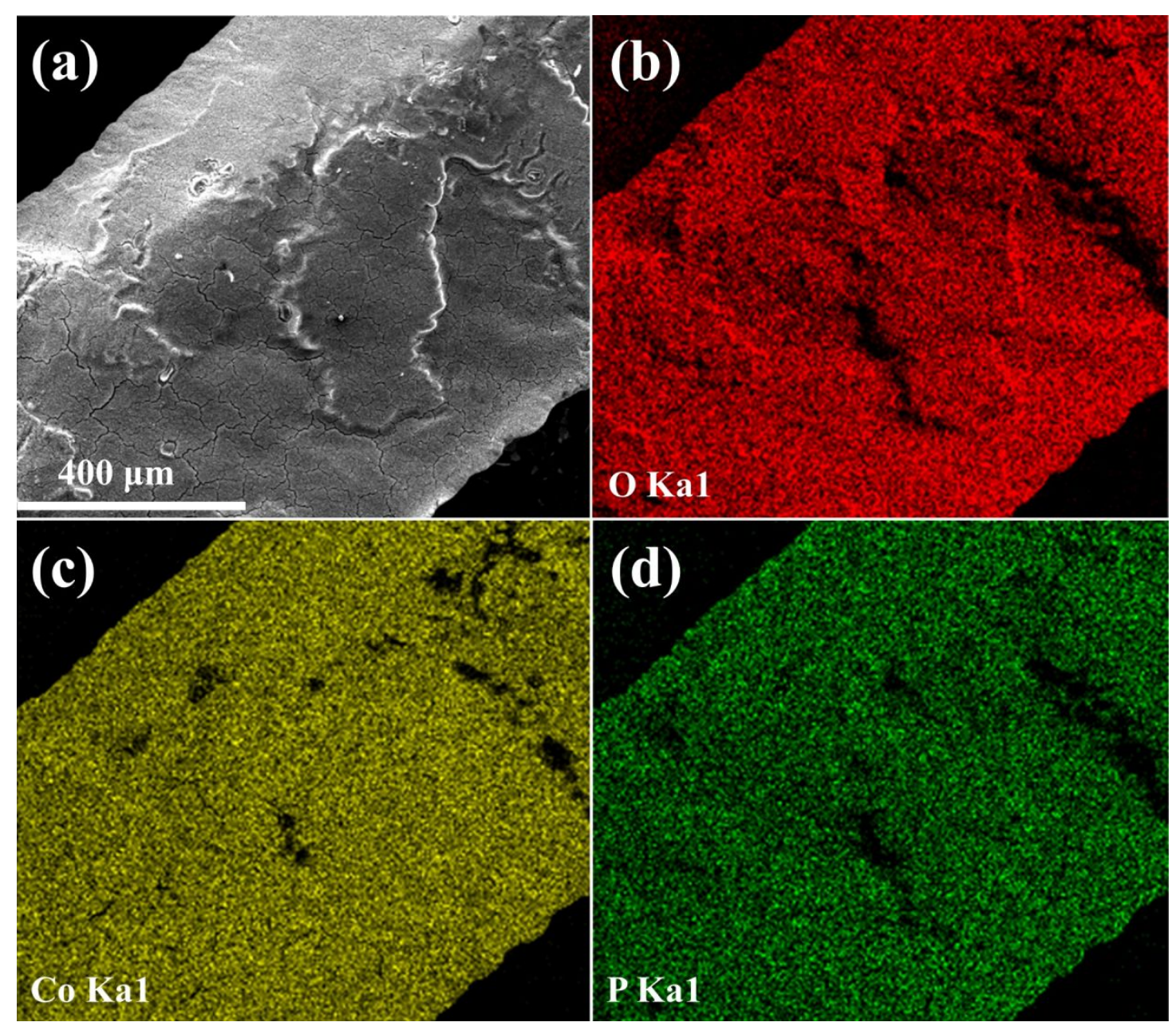

374 Figure S13. The elemental mapping images of $\mathrm{P}-\mathrm{Co}_{3} \mathrm{O}_{4}$. 

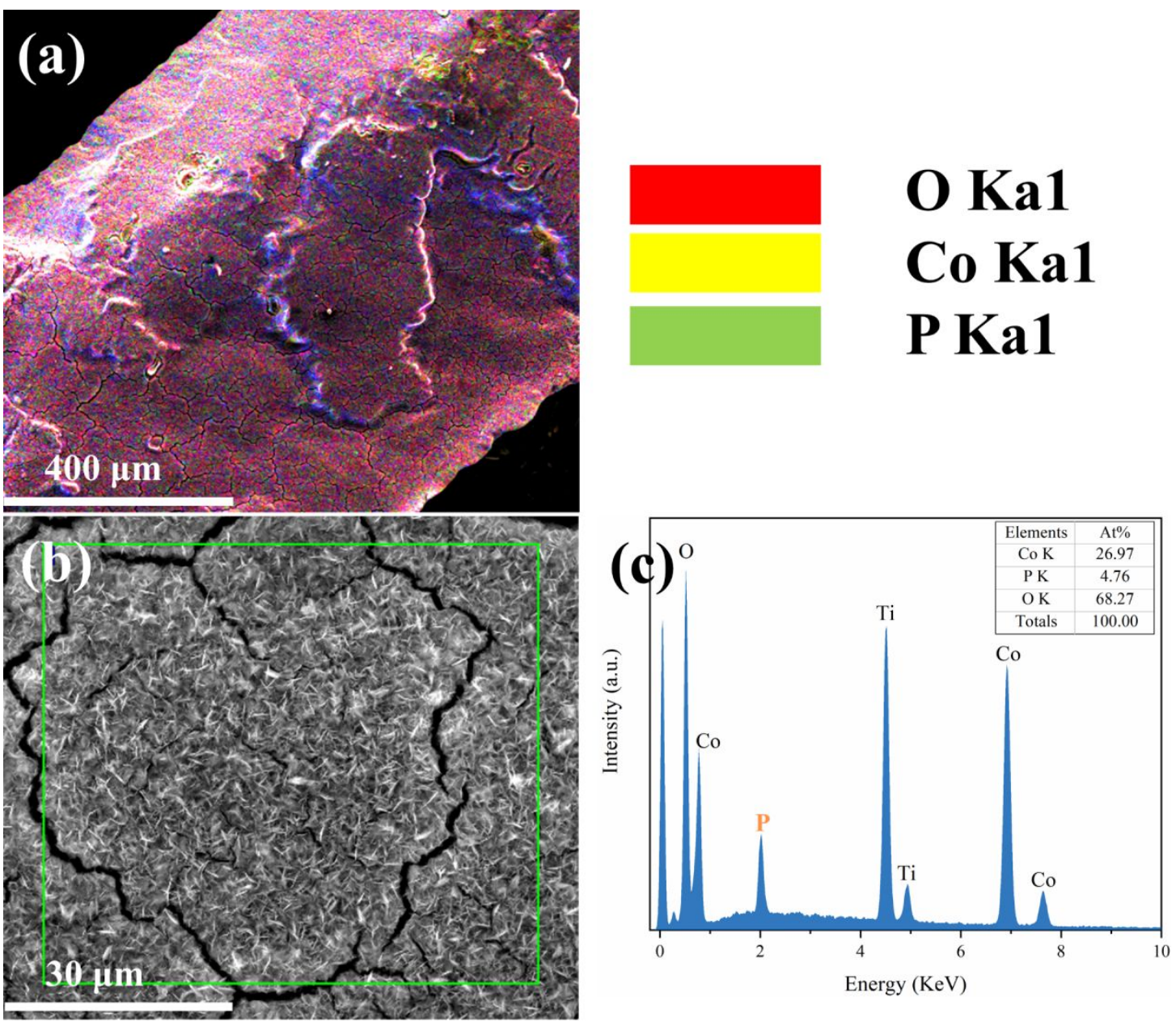

376 Figure $\mathrm{S} 14$. The elemental composition of $\mathrm{P}-\mathrm{Co}_{3} \mathrm{O}_{4}$. The $\mathrm{P}$-content atomic percentage on the surface is 377 around $4.76 \%$. 


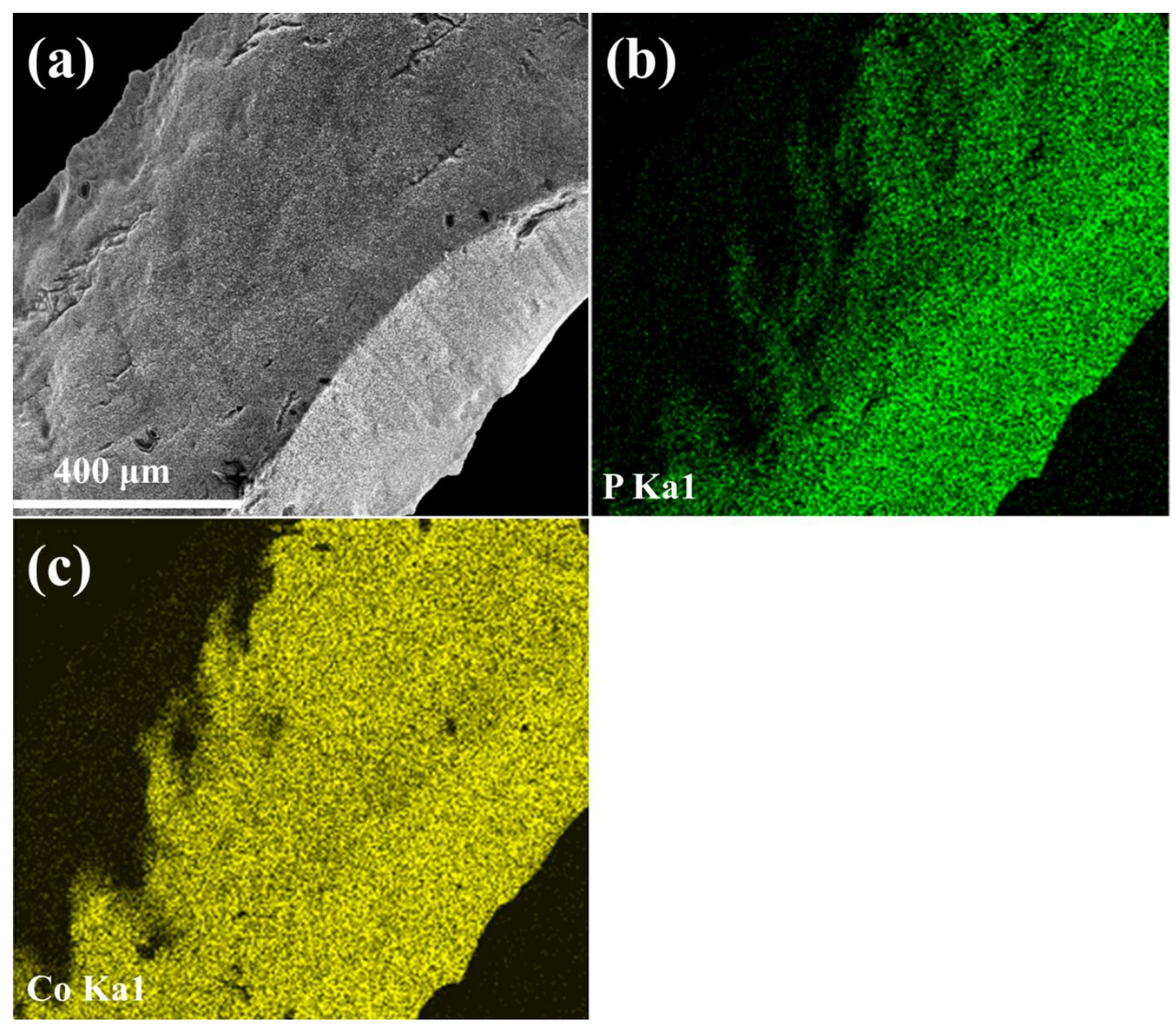

379 Figure S15. The elemental mapping images of CoP. 


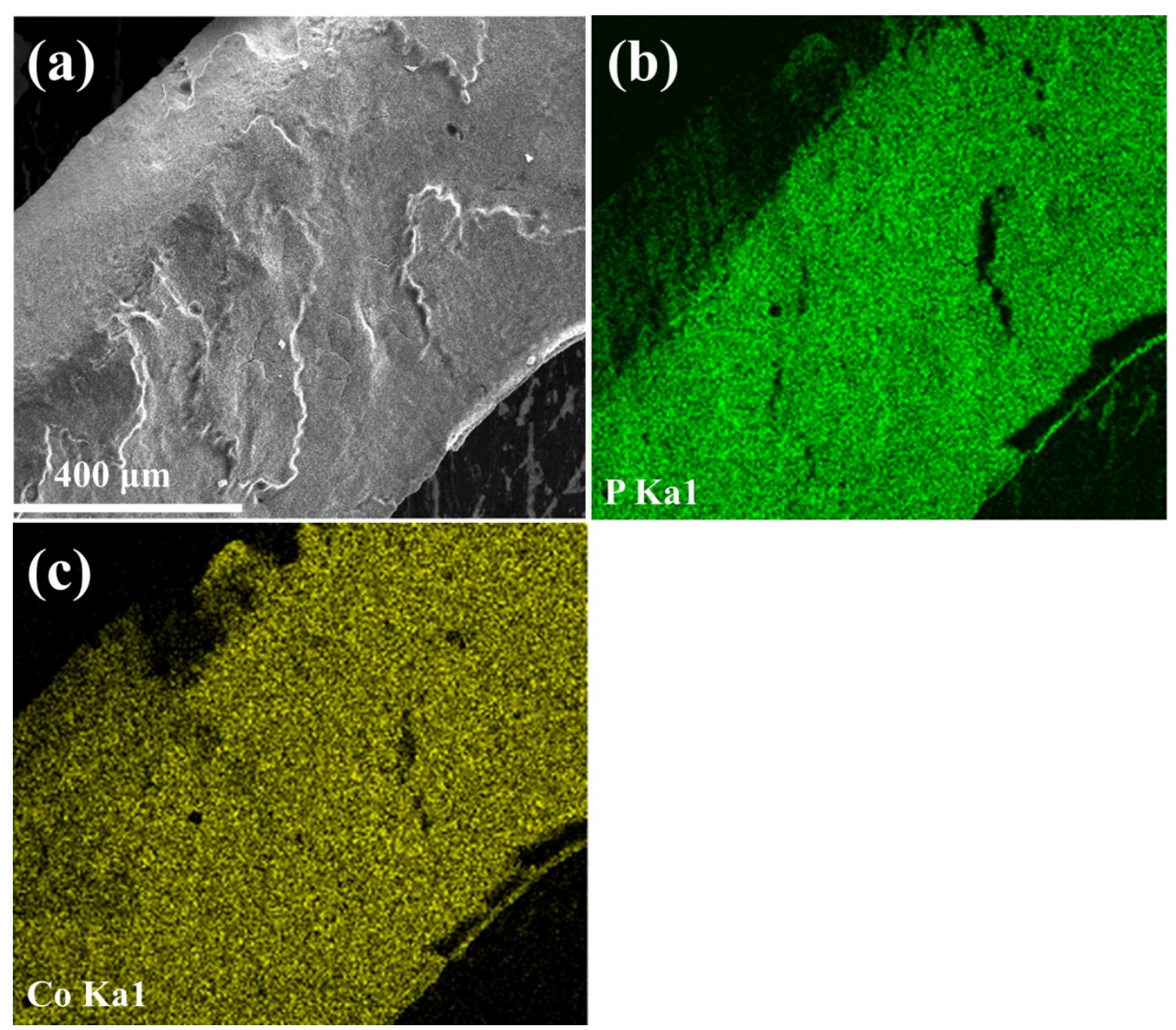

381 Figure S16. The elemental mapping images of over phosphatized CoP. 

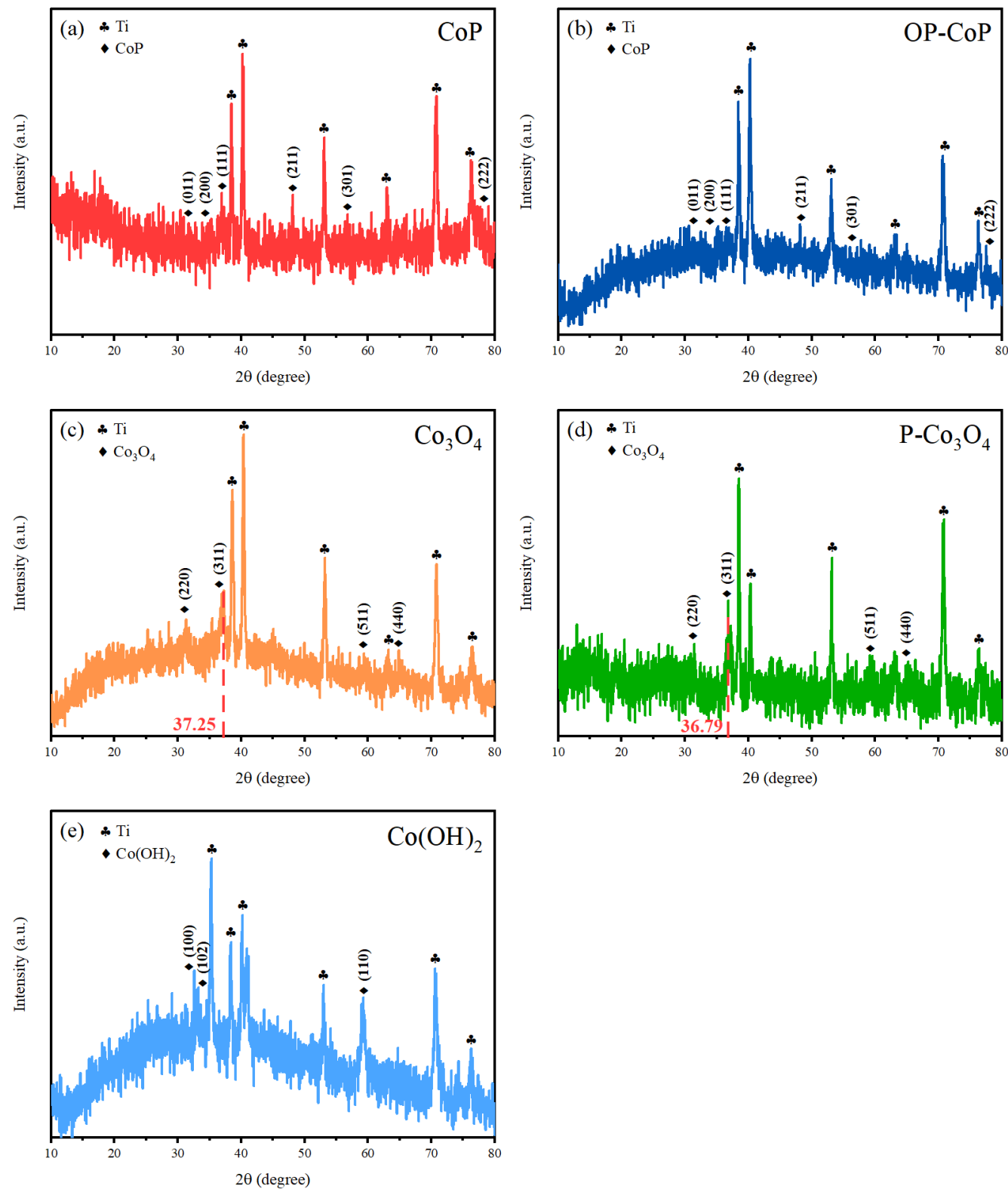

383 Figure S17. XRD images of different Co-based cathodes. As shown in (c) and (d), compared to $\mathrm{Co}_{3} \mathrm{O}_{4}$, the (311) peaks of $\mathrm{P}_{-} \mathrm{Co}_{3} \mathrm{O}_{4}$ shifts progressively in the negative direction with the $\mathrm{P}$ doping, proving that $385 \mathrm{P}$ was successfully filled into the lattice of $\mathrm{Co}_{3} \mathrm{O}_{4}$, which is consistent with our previous research ${ }^{15}$. 

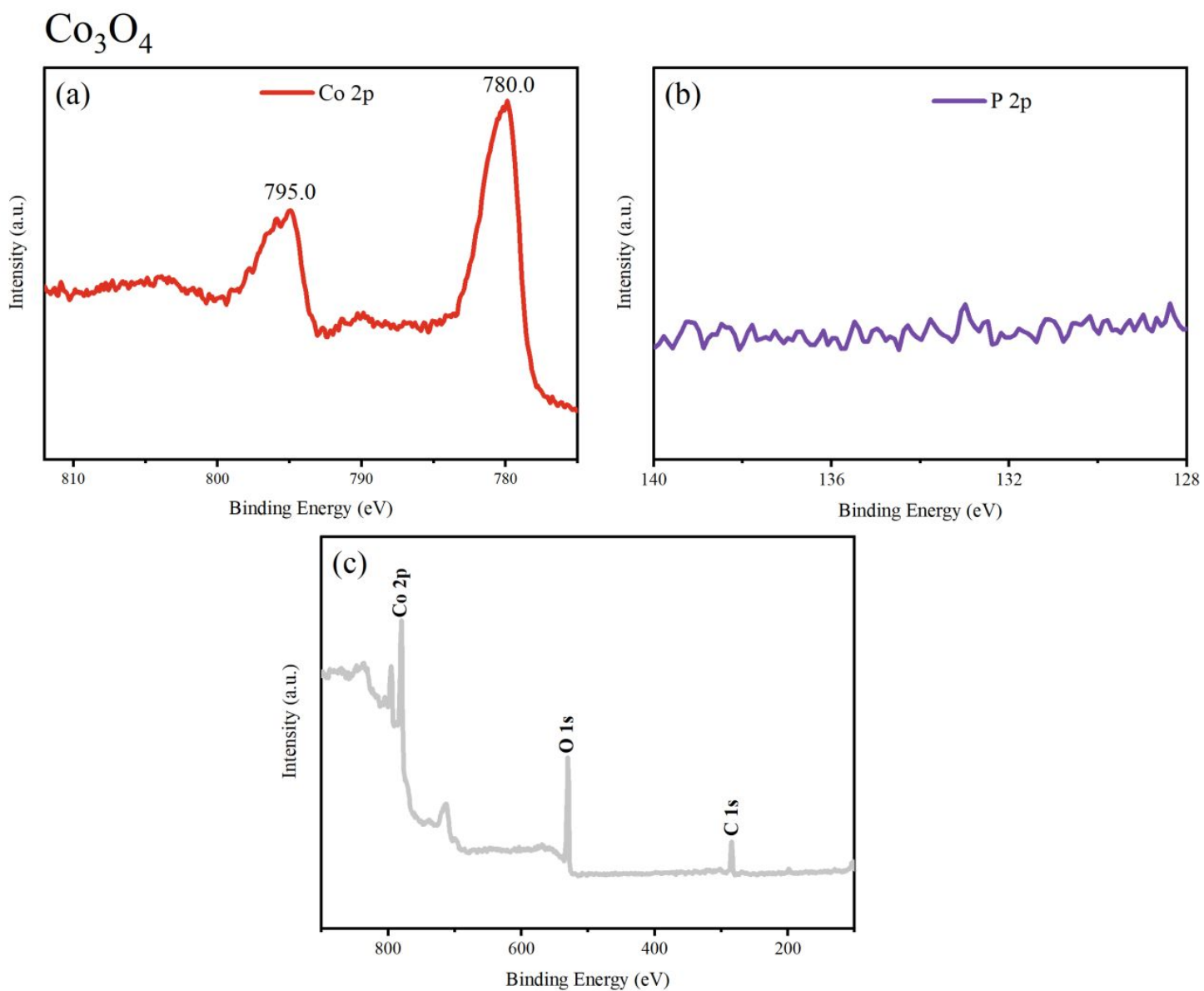

387 Figure S18. XPS images of $\mathrm{Co}_{3} \mathrm{O}_{4}$. Two peaks are apparent in the $\mathrm{Co}(2 \mathrm{p})$ region at 795.0 and $780.0 \mathrm{eV}$, 388 along with no peak in the $\mathrm{P}(2 \mathrm{p})$ region. 

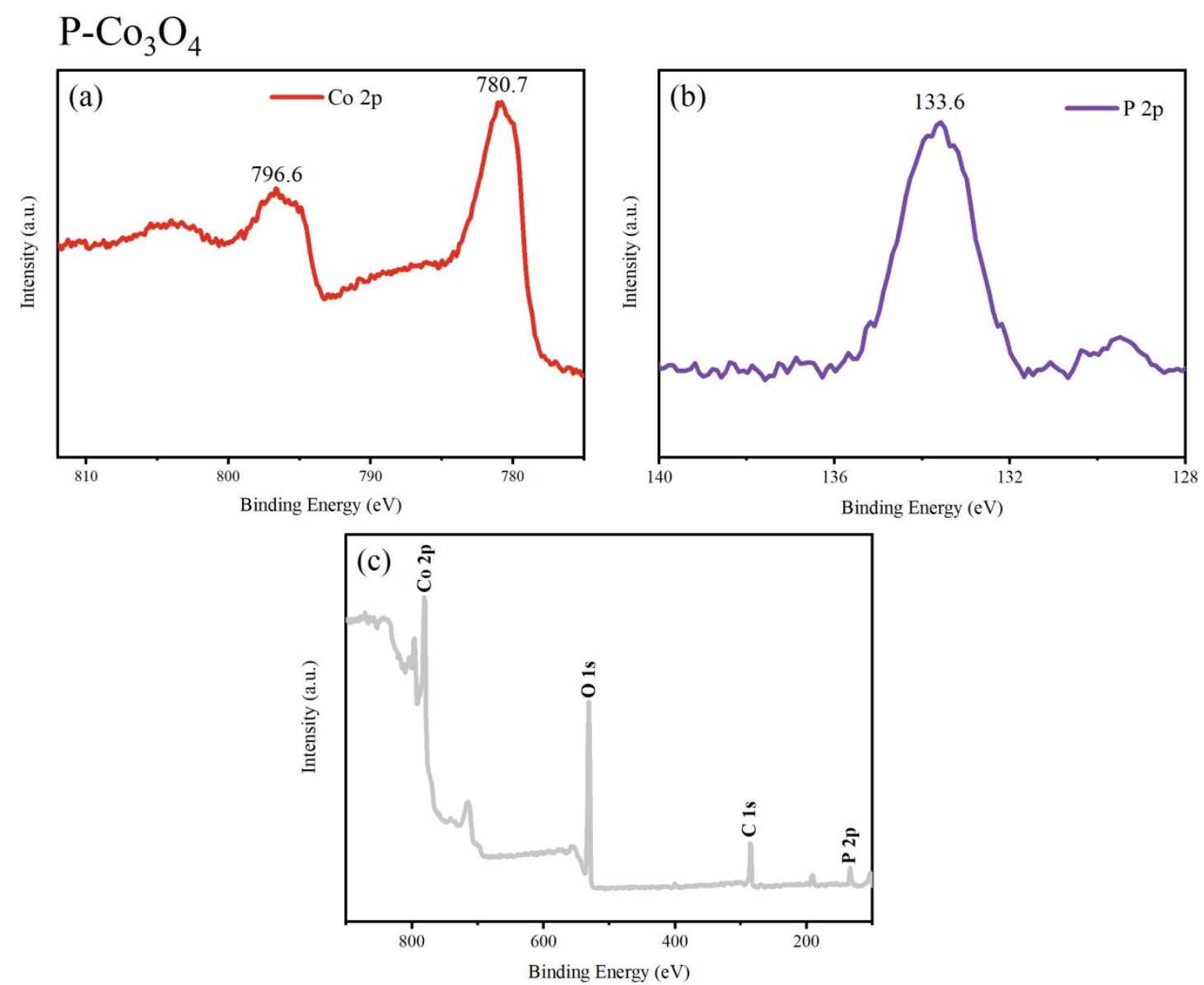

390 Figure S19. XPS images of $\mathrm{P}_{-} \mathrm{Co}_{3} \mathrm{O}_{4}$. Two peaks are apparent in the $\mathrm{Co}(2 \mathrm{p})$ region at 796.6 and $780.7 \mathrm{eV}$, 391 along with one peak in the $\mathrm{P}(2 \mathrm{p})$ region at $133.6 \mathrm{eV}$. Compared with $\mathrm{Co}_{3} \mathrm{O}_{4}, \mathrm{P}_{-} \mathrm{Co}_{3} \mathrm{O}_{4}$ exhibits higher $\mathrm{Co}$ $3922 p$ peaks binding energies, indicating the decreased electron density of Co species ${ }^{15}$. Besides, the obvious $393 \quad \mathrm{P}$ peak indicates that $\mathrm{P}$ element was successfully doped into the lattice of $\mathrm{Co}_{3} \mathrm{O}_{4}$. 

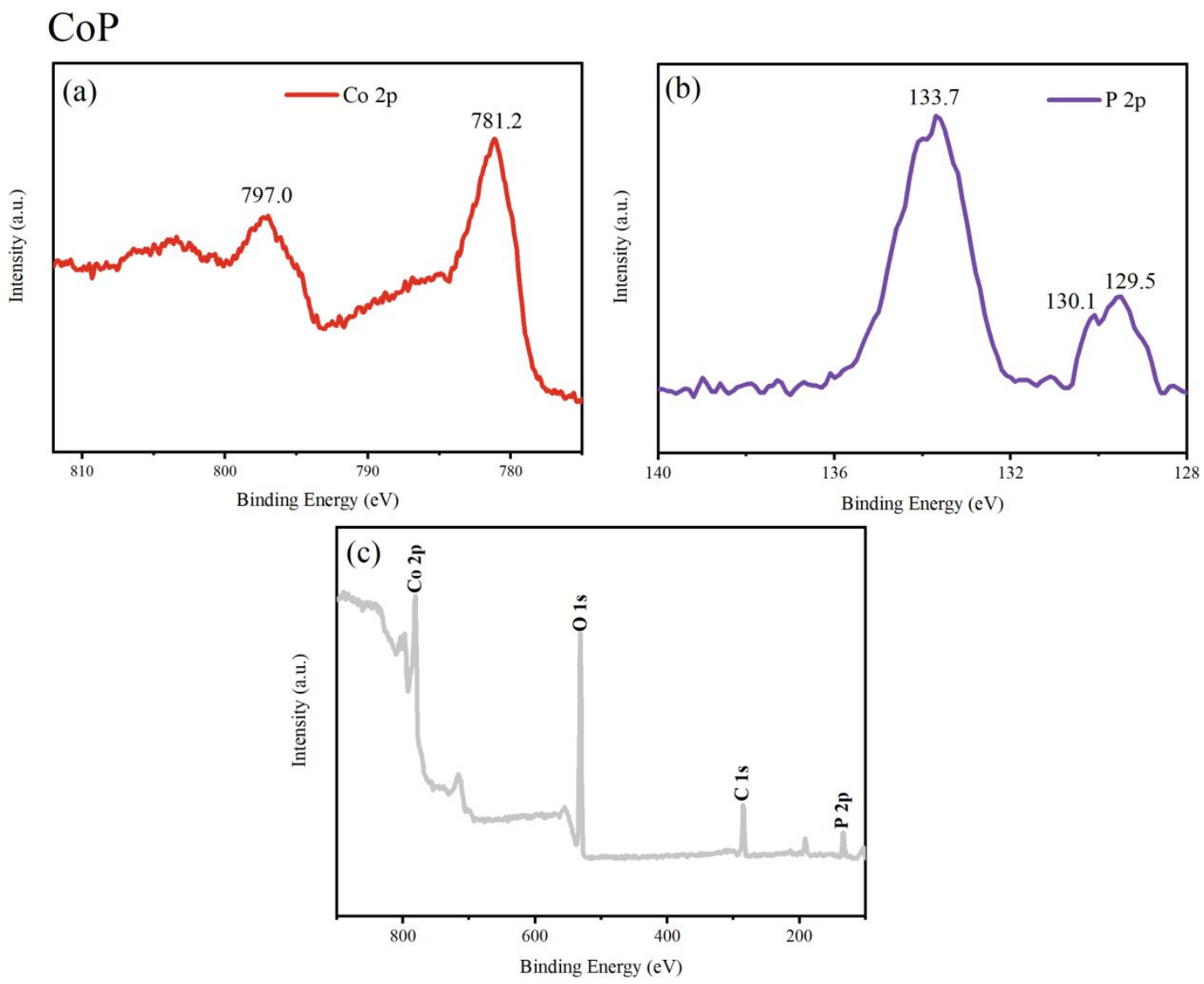

395 Figure S20. XPS images of CoP. Two peaks are apparent in the $\mathrm{Co}(2 \mathrm{p})$ region at 797.0 and $781.2 \mathrm{eV}$, 396 along with one peak in the $\mathrm{P}(2 \mathrm{p})$ region at $133.7,130.1$, and $129.5 \mathrm{eV}$. The peaks at 781.2 and $133.7 \mathrm{eV}$ 397 are assigned to oxidized $\mathrm{Co}$ and $\mathrm{P}$ species resulting from superficial oxidation of $\mathrm{CoP}^{16}$. The survey 398 spectrum also confirms the existence of oxygen in the sample. 

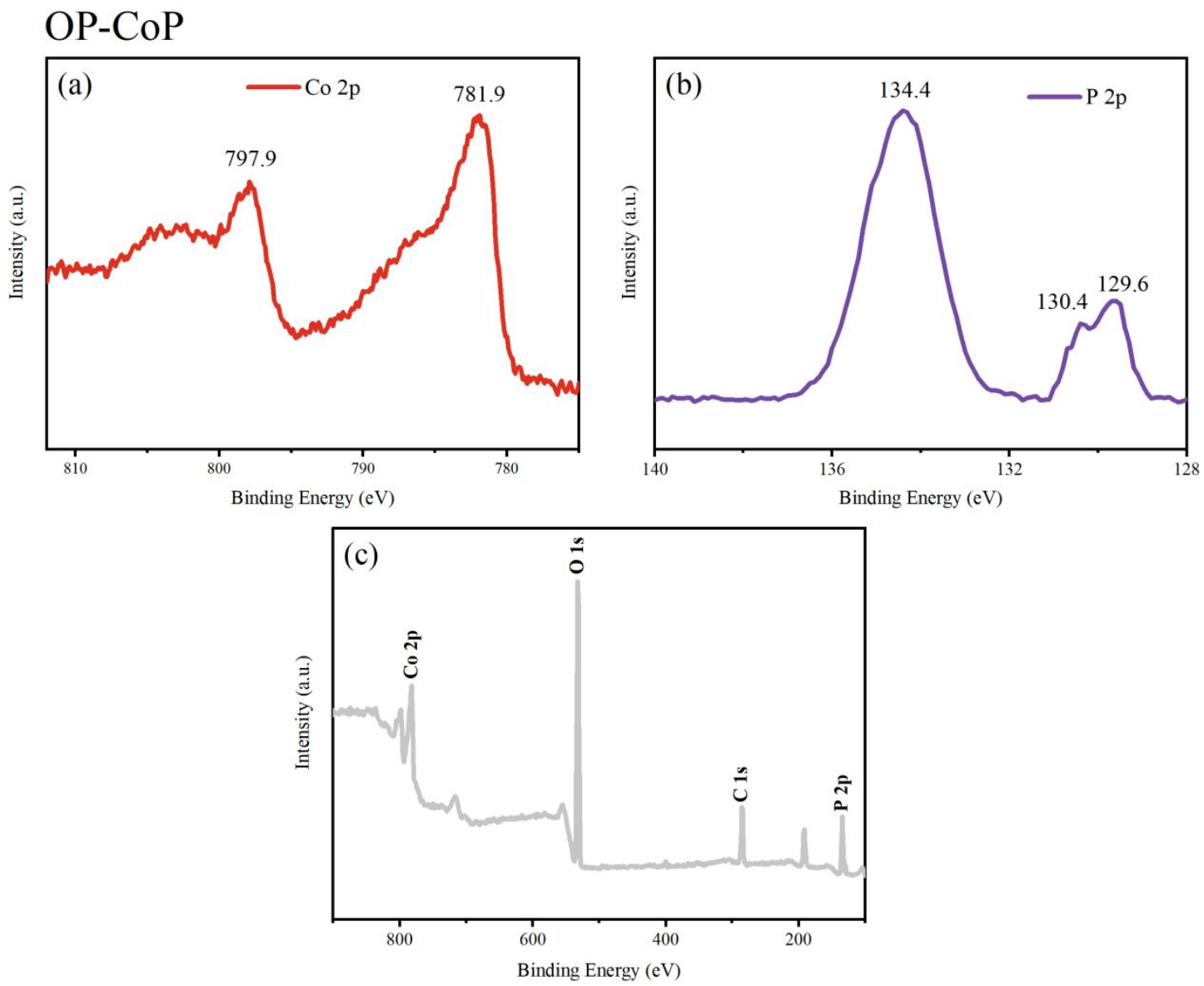

400 Figure S21. XPS images of over phosphatized CoP. Two peaks are apparent in the Co(2p) region at 797.9 401 and $781.9 \mathrm{eV}$, along with one peak in the $\mathrm{P}(2 \mathrm{p})$ region at $134.4130 .4,129.6 \mathrm{eV}$. There is no significant 402 difference from CoP. 

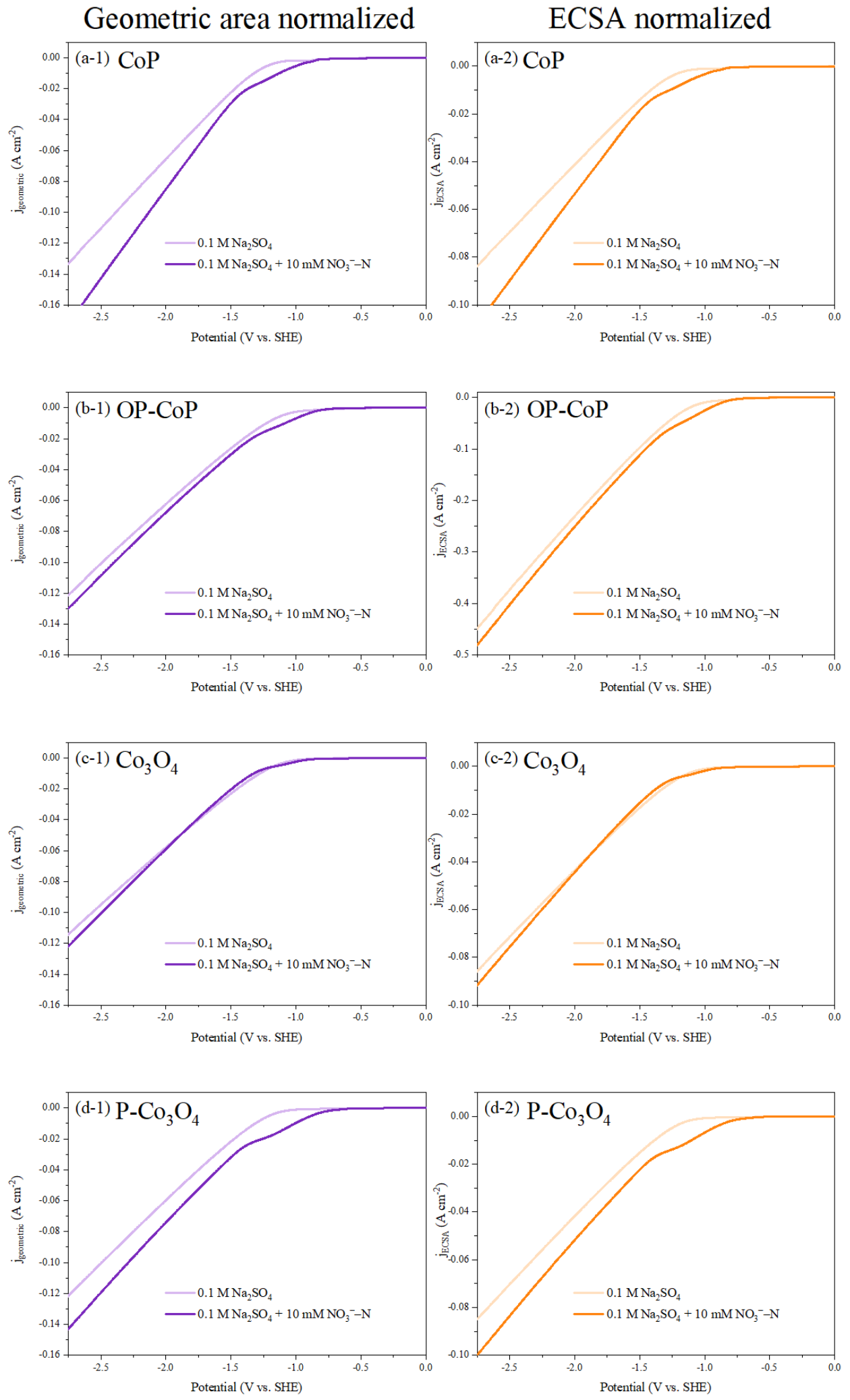

404 Figure S22. The current density, with or without presence of nitrate ions, on a geometric basis and normalized to the ECSA. Testing conditions: supporting electrolyte, $0.1 \mathrm{M} \mathrm{Na}_{2} \mathrm{SO}_{4}$ aqueous solution with 
406 and without $10 \mathrm{mM} \mathrm{NO}_{3}^{-} ; \mathrm{pH}, \sim 7.0$; standard two-chamber electrochemical cell separated by proton 407 exchange membrane, each chamber was filled with $50 \mathrm{~mL}$ electrolyte (stirred at a constant rate of 300 $408 \mathrm{rpm})$; counter electrode, Platinum foil $(1 \mathrm{~cm} \times 1 \mathrm{~cm})$; working electrode, various Co-based cathodes $(1$ $409 \mathrm{~cm} \times 1 \mathrm{~cm}$ ); electrode gap, $3.0 \mathrm{~cm}$; reference electrode, SCE; temperature, $\sim 25^{\circ} \mathrm{C}$. 

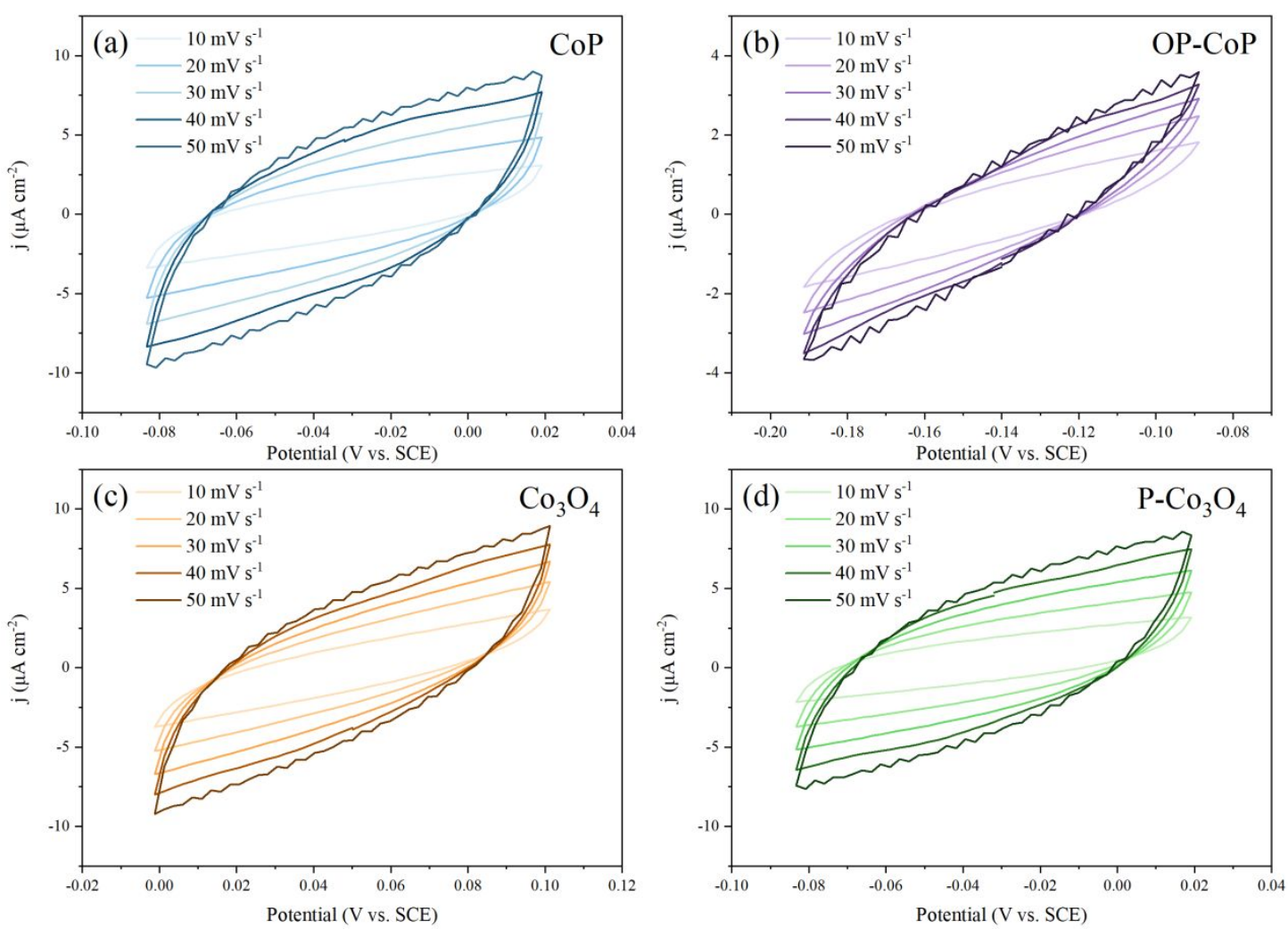

411 Figure S23. Cyclic voltammograms (CVs) within the non-faraday potential range. Basic testing

412 conditions: supporting electrolyte, $\mathrm{pH}, \sim 7.0$; standard two-chamber electrochemical cell separated by

413 proton exchange membrane, each chamber was filled with $50 \mathrm{~mL}$ electrolyte (stirred at a constant rate of

$414300 \mathrm{rpm})$; counter electrode, Platinum foil $(1 \mathrm{~cm} \times 1 \mathrm{~cm})$; working electrode, various Co-based cathodes

$415(1 \mathrm{~cm} \times 1 \mathrm{~cm})$; electrode gap, $3.0 \mathrm{~cm}$; reference electrode, $\mathrm{SCE}$; temperature, $\sim 25{ }^{\circ} \mathrm{C}$; Specific testing conditions: electrolyte, $0.1 \mathrm{M} \mathrm{Na}_{2} \mathrm{SO}_{4}$; scan rate, $10-50 \mathrm{mV} \mathrm{s}^{-1}$. 


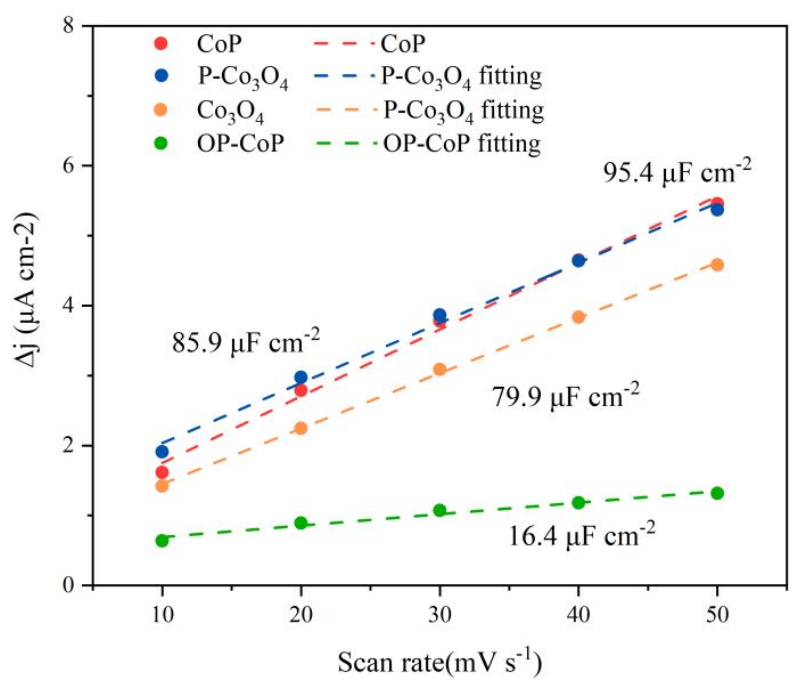

418 Figure S24. Calculation of double capacitance for different cathodes based on a $1 \mathrm{~cm}^{2}$ electrode geometric

419 surface area. The electroactive surface area was further calculated based on double capacitance divided 420 by standard electroactive surface area for standard values $\left.(60 \mu \mathrm{F} \mathrm{cm})^{-2}\right)$. 


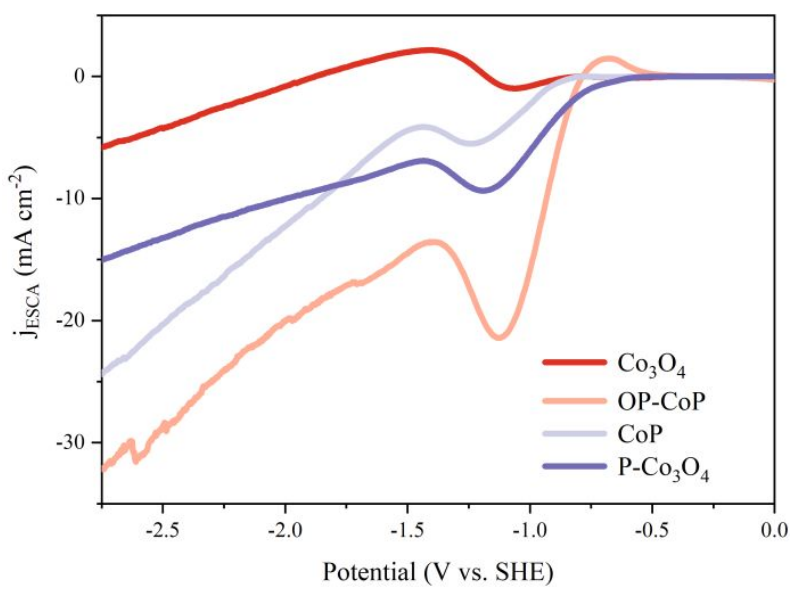

422 Figure S25. Differential current density based on ESCA normalized linear cyclic voltammetry (LSV)

423 curve. Testing conditions: supporting electrolyte, $0.1 \mathrm{M} \mathrm{Na}_{2} \mathrm{SO}_{4}$ aqueous solution with and without 10 $424 \mathrm{mM} \mathrm{NO}{ }_{3}^{-} ; \mathrm{pH}, \sim 7.0$; standard two-chamber electrochemical cell separated by proton exchange 425 membrane, each chamber was filled with $50 \mathrm{~mL}$ electrolyte (stirred at a constant rate of $300 \mathrm{rpm}$ ); counter 426 electrode, Platinum foil $(1 \mathrm{~cm} \times 1 \mathrm{~cm})$; working electrode, various Co-based cathodes $(1 \mathrm{~cm} \times 1 \mathrm{~cm})$; 427 electrode gap, $3.0 \mathrm{~cm}$; reference electrode, SCE; temperature, $\sim 25{ }^{\circ} \mathrm{C}$. 

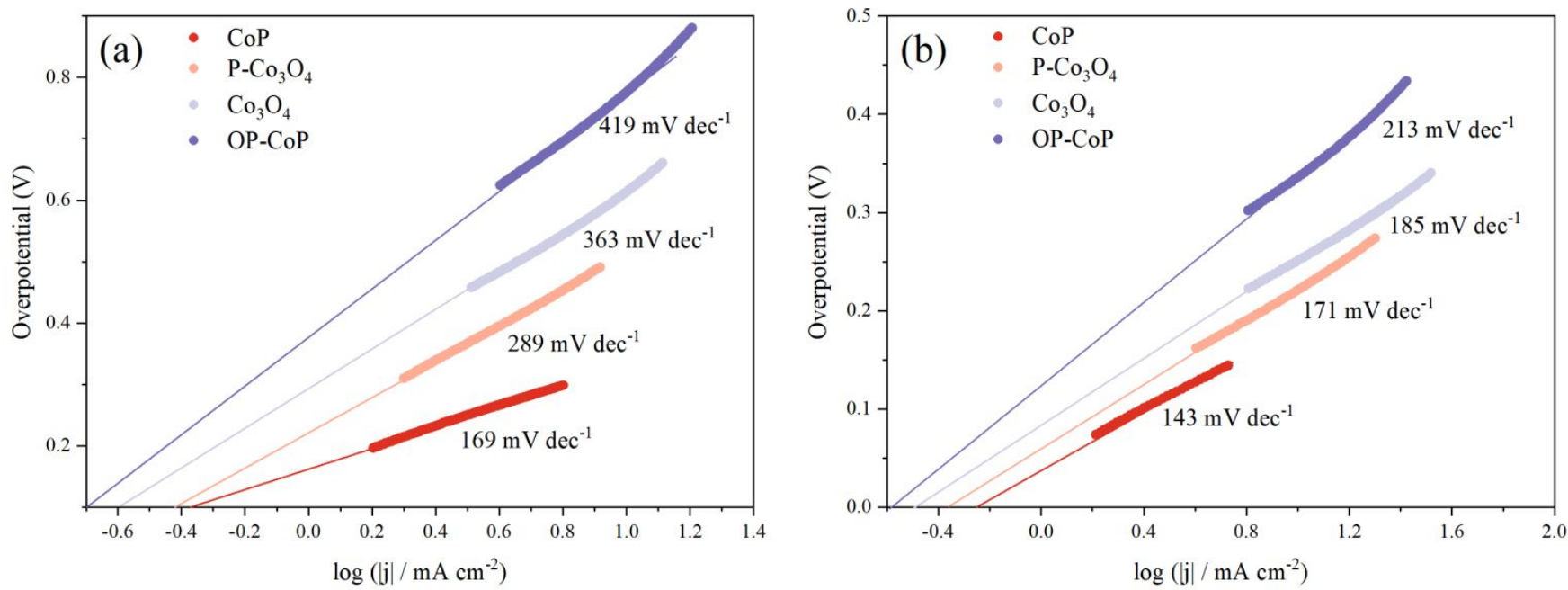

\begin{tabular}{|c|c|c|}
\hline (a) $0.1 \mathrm{M} \mathrm{Na} 2 \mathrm{SO} 4$ & $\mathrm{j}(\mathrm{mA} \mathrm{cm}-2)$ & $\log (\mathrm{j} \mid / \mathrm{mA} \mathrm{cm}-2)$ \\
\hline $\mathrm{CoP}$ & 0.40 & -0.398 \\
\hline $\mathrm{P}-\mathrm{Co} 3 \mathrm{O} 4$ & 0.38 & -0.420 \\
\hline $\mathrm{Co3O} 4$ & 0.25 & -0.602 \\
\hline OP-CoP & 0.20 & -0.699 \\
\hline
\end{tabular}

\begin{tabular}{|c|c|c|}
\hline (b) $0.5 \mathrm{M} \mathrm{KOH}$ & $\mathrm{j}(\mathrm{mA} \mathrm{cm}-2)$ & $\log (|\mathrm{j}| / \mathrm{mA} \mathrm{cm}-2)$ \\
\hline $\mathrm{CoP}$ & 0.55 & -0.260 \\
\hline $\mathrm{P}-\mathrm{Co} 3 \mathrm{O} 4$ & 0.44 & -0.362 \\
\hline $\mathrm{Co3O} 4$ & 0.31 & -0.509 \\
\hline $\mathrm{OP}-\mathrm{CoP}$ & 0.26 & -0.585 \\
\hline
\end{tabular}

429 Figure S26. Tafel plots and exchange current density $\left(\mathrm{j}_{0}\right)$ in $0.1 \mathrm{M} \mathrm{Na}_{2} \mathrm{SO}_{4}(\mathrm{a})$ and $0.5 \mathrm{M} \mathrm{KOH}(\mathrm{b})$. 

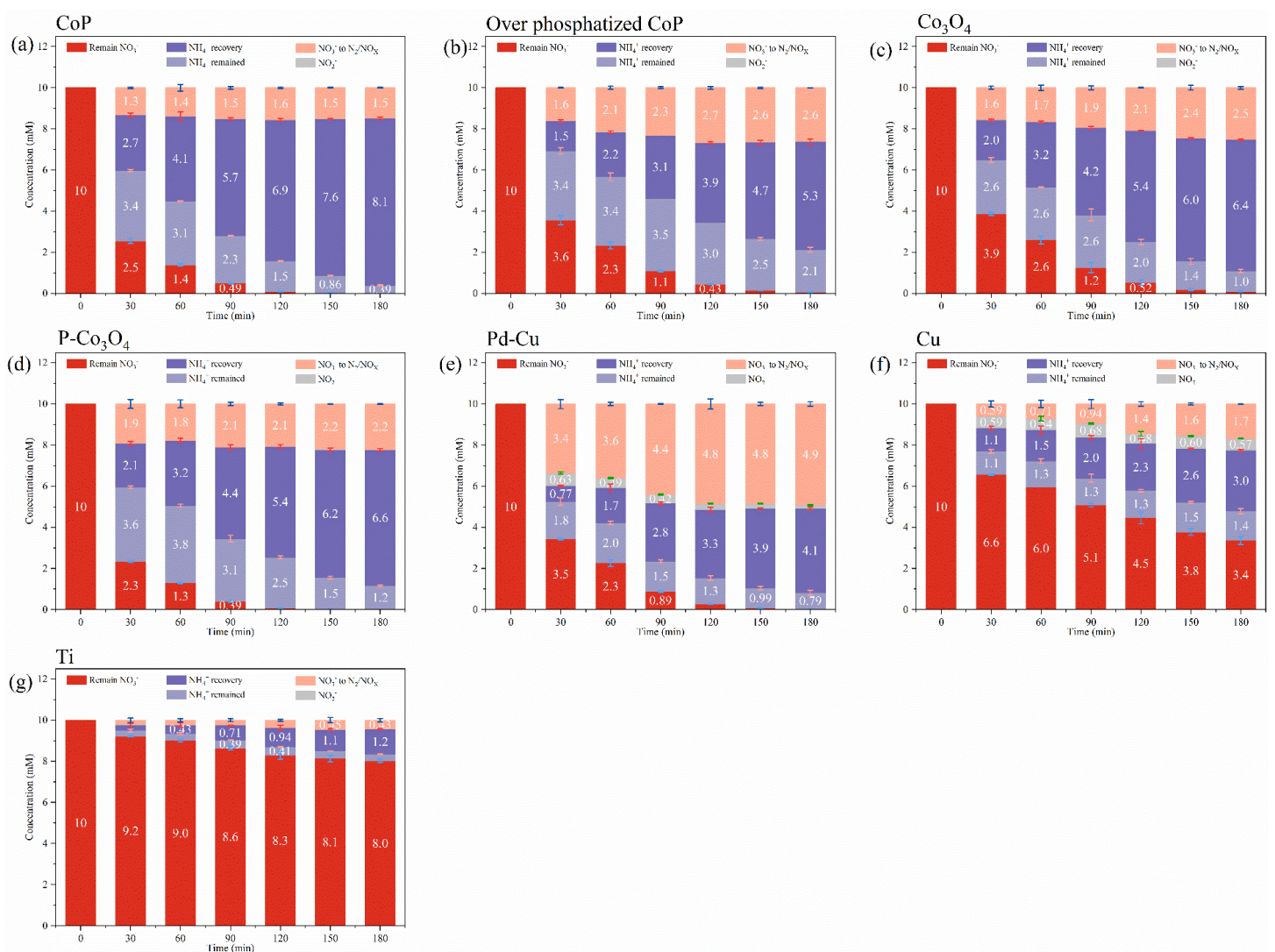

431 Figure S27. The comparation of different cathodes. Basic testing conditions were the same as Figure S4

432 except for various cathodes were investigated. Specific testing conditions: $\mathrm{NO}_{3}{ }^{-}$concentration, $10 \mathrm{mM}$;

$433 \mathrm{pH}, \sim 7.0 ; \mathrm{Cl}^{-}, 0 \mathrm{mg} \mathrm{L}{ }^{-1}, \mathrm{FGM}, 0.45 \mu \mathrm{m}$; applied potential, $-2.4 \mathrm{~V}$ versus SHE without IR correction. 


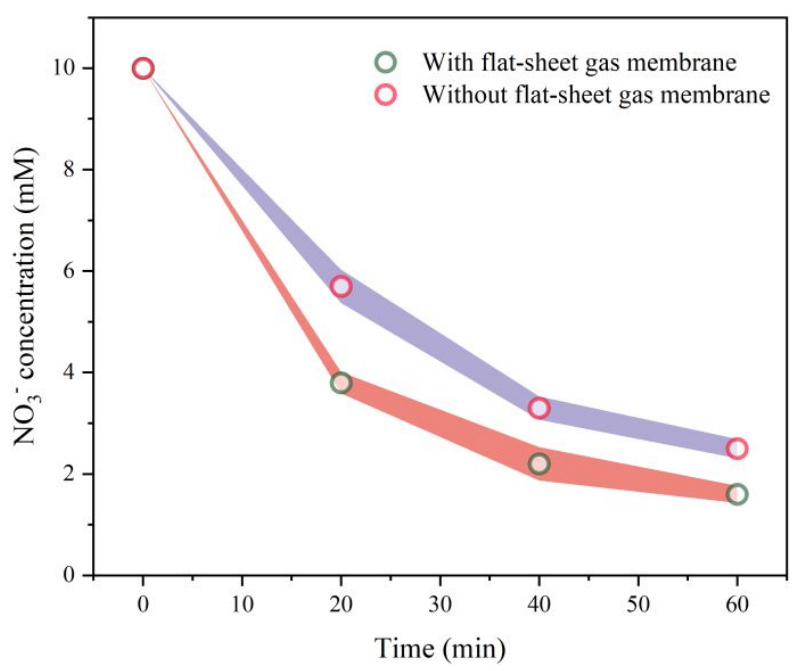

435 Figure S28. Nitrate reduction experiments of CoP cathode with and without ammonia separation (achieve 436 by placing and no-placing FGM). Basic testing conditions were the same as Figure S4. Specific testing 437 conditions: $\mathrm{NO}_{3}{ }^{-}$concentration, $10 \mathrm{mM} ; \mathrm{pH}, \sim 7.0 ; \mathrm{Cl}^{-}, 0 \mathrm{mg} \mathrm{L}{ }^{-1}, \mathrm{FGM}, 0.45 \mu \mathrm{m}$; applied potential, -2.4 438 V versus SHE without IR correction. 

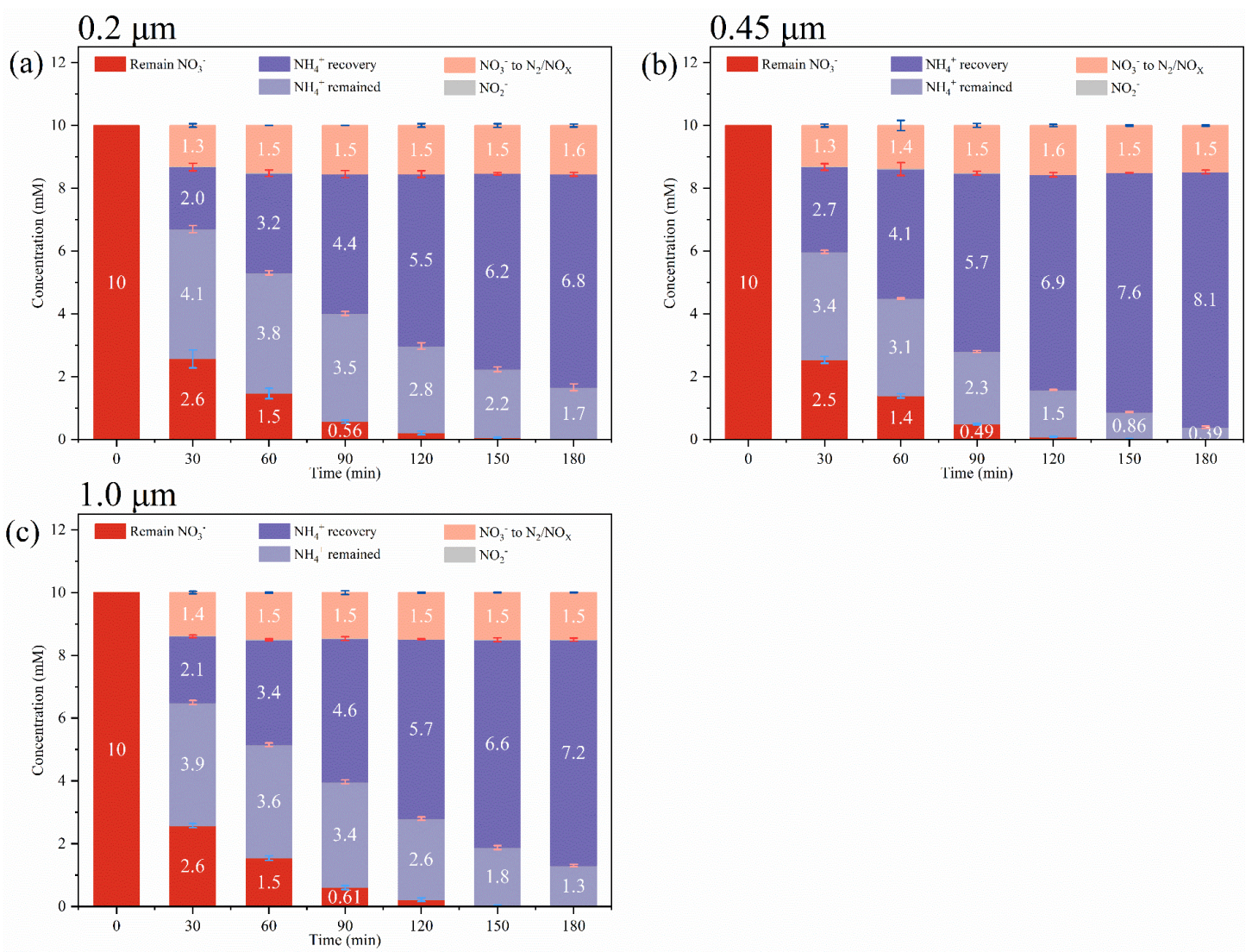

440 Figure S 29. The effect of FGM pore diameter size on detailed evolving trends towards the yield efficiency 441 for nitrate, ammonia/ammonium, nitrite, and $\mathrm{N}_{2} / \mathrm{NO}_{\mathrm{X}}$ of CoP cathode fabricated ENRRA reactor. Basic 442 testing conditions were the same as Figure S4. Specific testing conditions: $\mathrm{NO}_{3}{ }^{-}$concentration, $10 \mathrm{mM}$; $443 \mathrm{pH}, \sim 7.0 ; \mathrm{Cl}^{-}, 0 \mathrm{mg} \mathrm{L}{ }^{-1}$; applied potential, $-2.4 \mathrm{~V}$ versus SHE without IR correction; various FGM with 444 different pore sizes. 


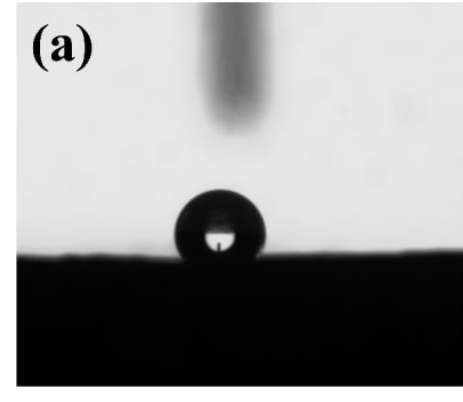

\section{(b)}

(c)

446 Figure S30. The contact angle of (a) $0.20 \mu \mathrm{m}$, (b) $0.45 \mu \mathrm{m}$, (c) $1.0 \mu \mathrm{m}$ FGM. 

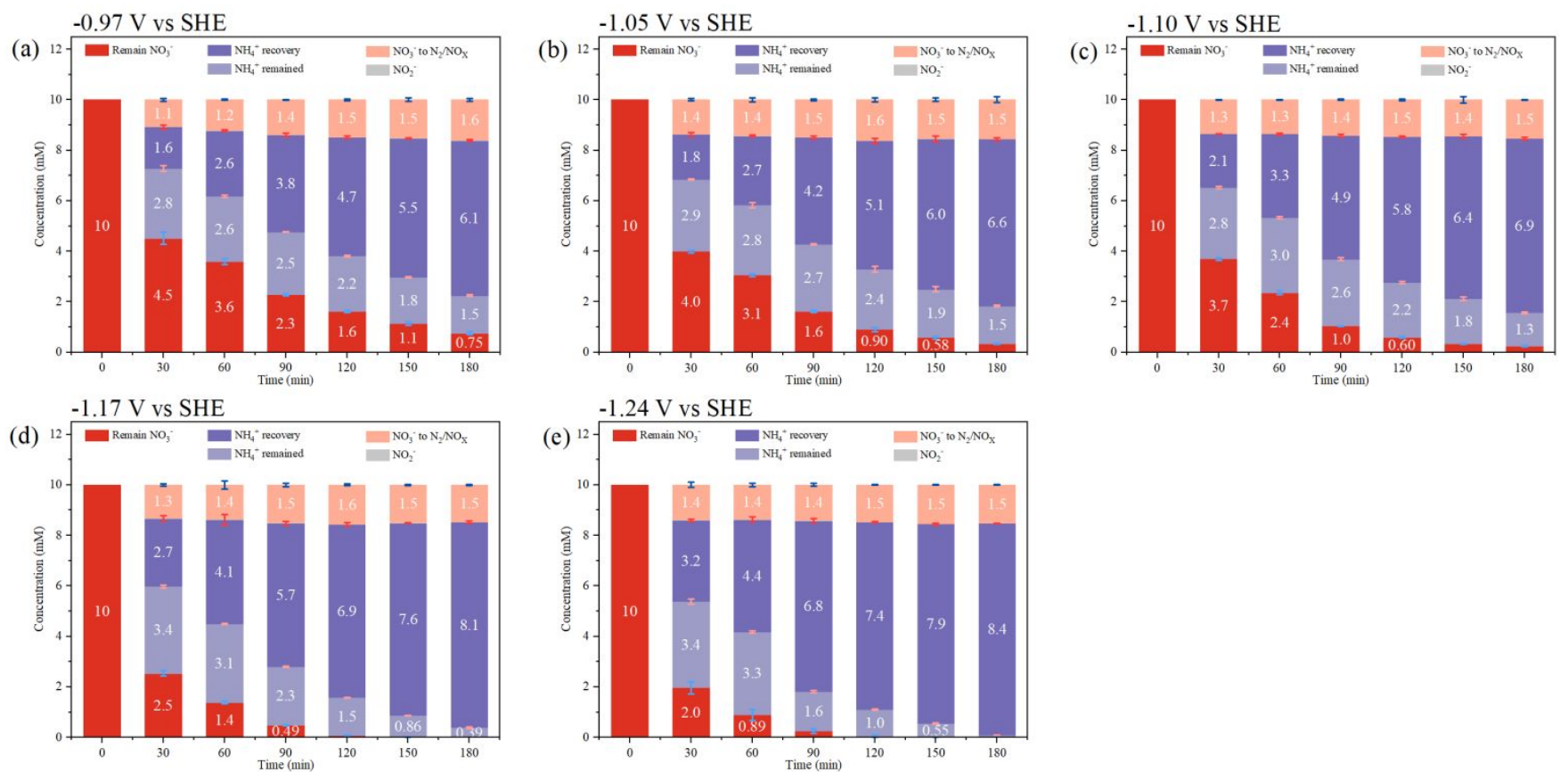

448 Figure S31. The effect of potential on detailed evolving trends towards the yield efficiency for nitrate,

449 ammonia/ammonium, nitrite, and $\mathrm{N}_{2} / \mathrm{NO}_{\mathrm{X}}$ of CoP cathode fabricated ENRRA reactor. The potentials 450 were converted to the SHE scales with IR compensation. Basic testing conditions were the same as Figure 451 S4. Specific testing conditions: $\mathrm{NO}_{3}^{-}$concentration, $10 \mathrm{mM} ; \mathrm{pH}, \sim 7.0 ; \mathrm{Cl}^{-}, 0 \mathrm{mg} \mathrm{L}{ }^{-1} ; \mathrm{FGM}, 0.45 \mu \mathrm{m}$; various applied potentials (versus SHE with IR correction) were investigated. 

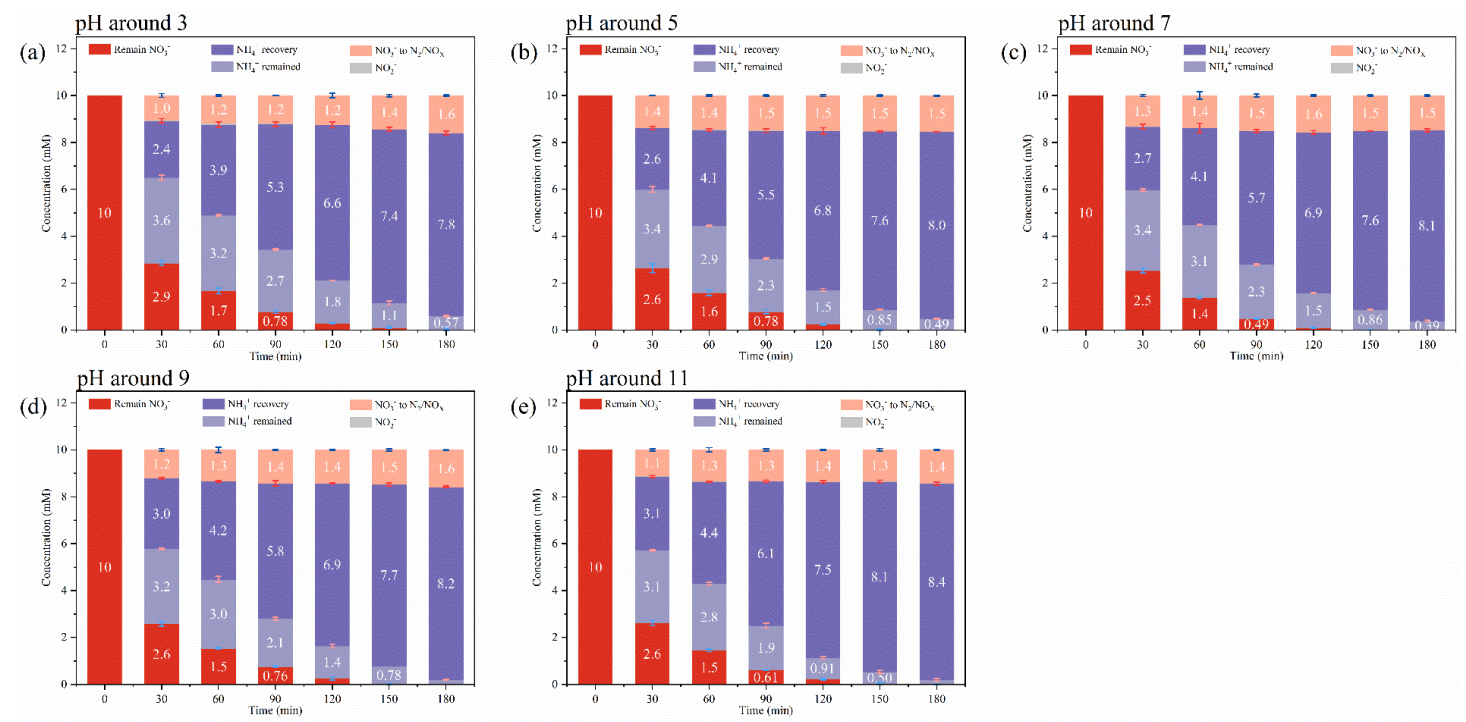

454 Figure $\mathrm{S} 32$. The effect of $\mathrm{pH}$ on detailed evolving trends towards the yield efficiency for nitrate, 455 ammonia/ammonium, nitrite, and $\mathrm{N}_{2} / \mathrm{NO}_{\mathrm{X}}$ of $\mathrm{CoP}$ cathode fabricated ENRRA reactor. Basic testing 456 conditions were the same as Figure S4. Specific testing conditions: $\mathrm{NO}_{3}^{-}$concentration, $10 \mathrm{mM} ; \mathrm{Cl}^{-}, 0$ $457 \mathrm{mg} \mathrm{L}{ }^{-1}$; applied potential, $-2.4 \mathrm{~V}$ versus SHE without IR correction; FGM, $0.45 \mu \mathrm{m}$; various $\mathrm{pH}$ were 458 investigated. 

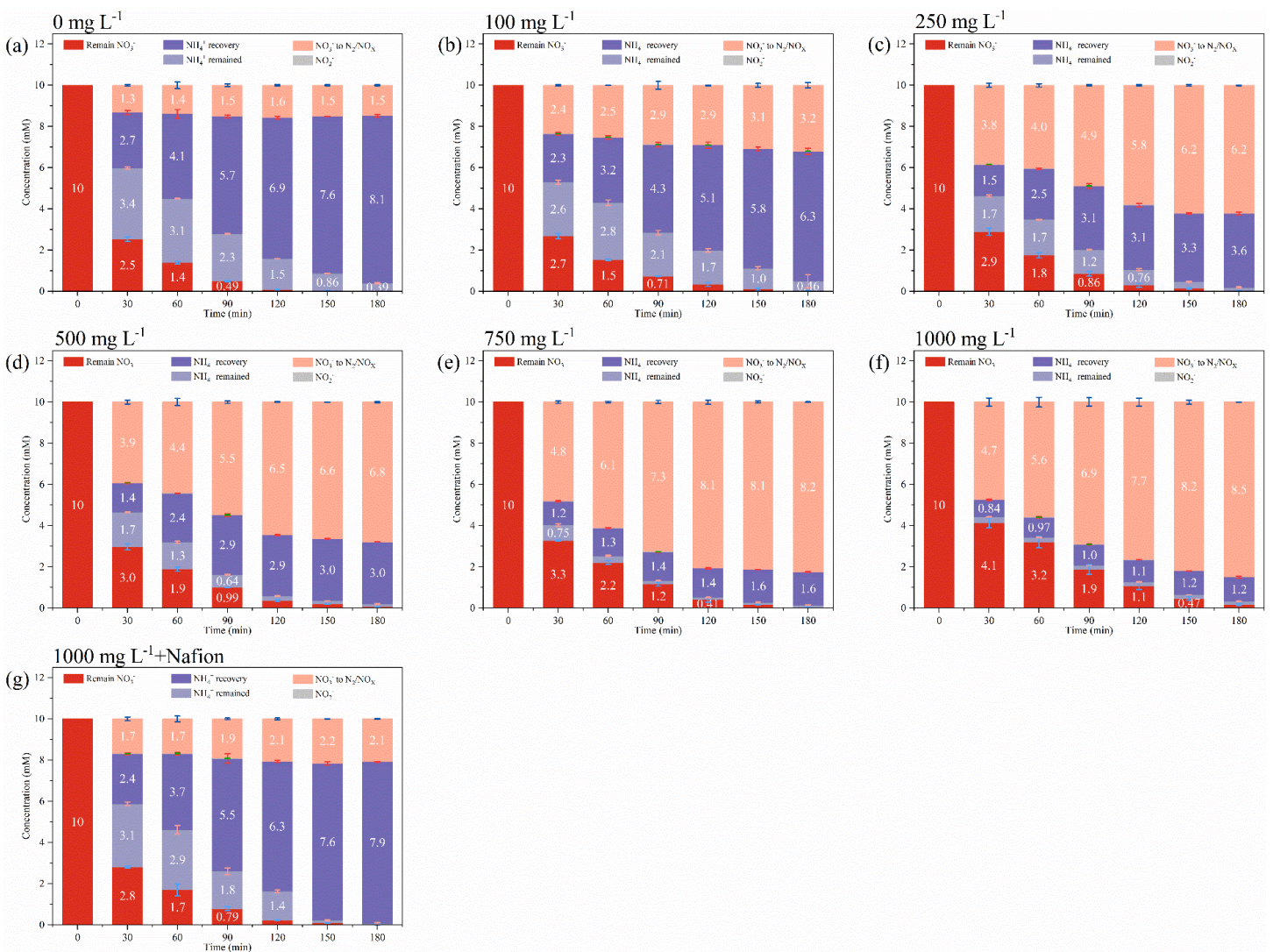

460 Figure S33. The effect of $\mathrm{Cl}^{-}$concentration on detailed evolving trends towards the yield efficiency for 461 nitrate, ammonia/ammonium, nitrite, and $\mathrm{N}_{2} / \mathrm{NO}_{\mathrm{X}}$ of $\mathrm{CoP}$ cathode fabricated ENRRA reactor. Basic 462 testing conditions were the same as Figure S4. Specific testing conditions: $\mathrm{NO}_{3}{ }^{-}$concentration, $10 \mathrm{mM}$; $463 \mathrm{pH}, \sim 7.0$; applied potential, $-2.4 \mathrm{~V}$ versus SHE without IR correction; FGM, 0.45 $\mu \mathrm{m}$; various $\mathrm{Cl}^{-}$ 464 concentrations were investigated. 

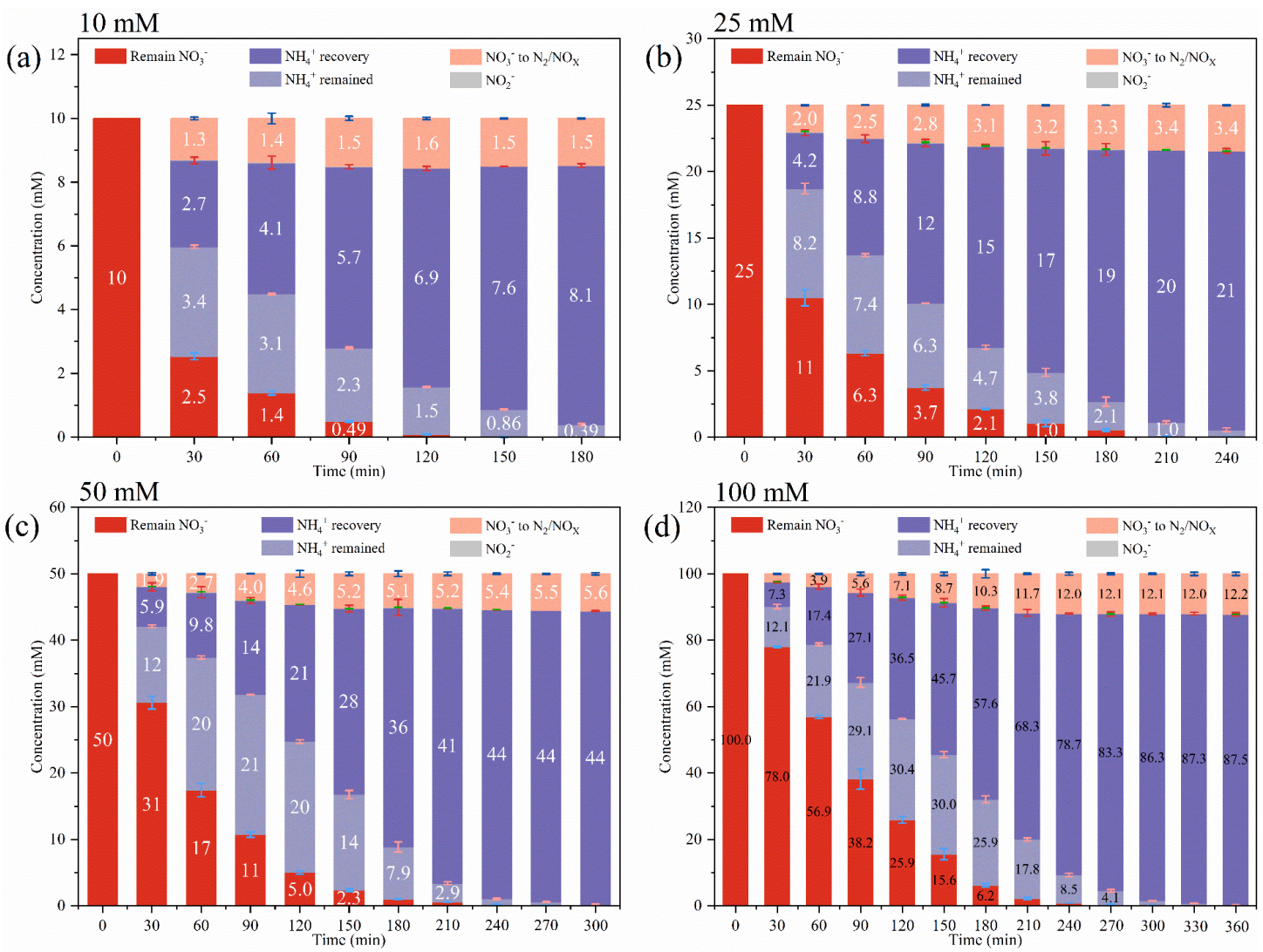

466 Figure S34. The effect of nitrate concentration on detailed evolving trends towards the yield efficiency 467 for nitrate, ammonia/ammonium, nitrite, and $\mathrm{N}_{2} / \mathrm{NO}_{\mathrm{X}}$ of $\mathrm{CoP}$ cathode fabricated ENRRA reactor. Basic 468 testing conditions were the same as Figure S4. Specific testing conditions: $\mathrm{Cl}^{-}, 0 \mathrm{mg} \mathrm{L}{ }^{-1} ; \mathrm{pH}, \sim 7.0$; applied potential, $-2.4 \mathrm{~V}$ versus SHE without IR correction; FGM, $0.45 \mu \mathrm{m}$; various nitrate concentrations were investigated. 

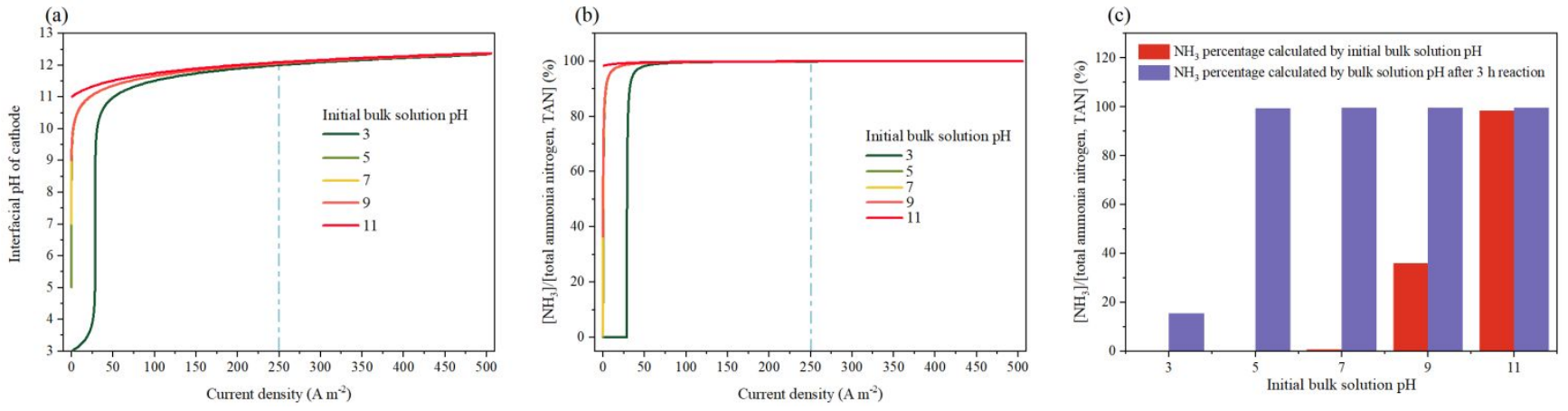

472 Figure S35. The relationship between current density with interfacial $\mathrm{pH}$ of cathode (a) and $\left[\mathrm{NH}_{3}\right] /[$ total 473 ammonia nitrogen, TAN] (b). The calculation detail is shown in "Interfacial pH calculation" part below.

474 The relationship between initial bulk solution $\mathrm{pH}$ and $\left[\mathrm{NH}_{3}\right] /[$ total ammonia nitrogen, TAN] (c). The 475 calculation in figure (c) was based on: $\left[\mathrm{NH}_{3}\right] /[$ total ammonia nitrogen, $\mathrm{TAN}]=10^{\mathrm{pH}} /\left(\mathrm{e}^{21.3}+10^{\mathrm{pH}}\right)$. The 476 initial and finial measured solution $\mathrm{pH}$ after $3 \mathrm{~h}$ reaction were: initial 3-finial 8.51; initial 5-finial 11.41; 477 initial 7-finial 11.52; initial 9-finial 11.54; initial 11-finial 11.72. 


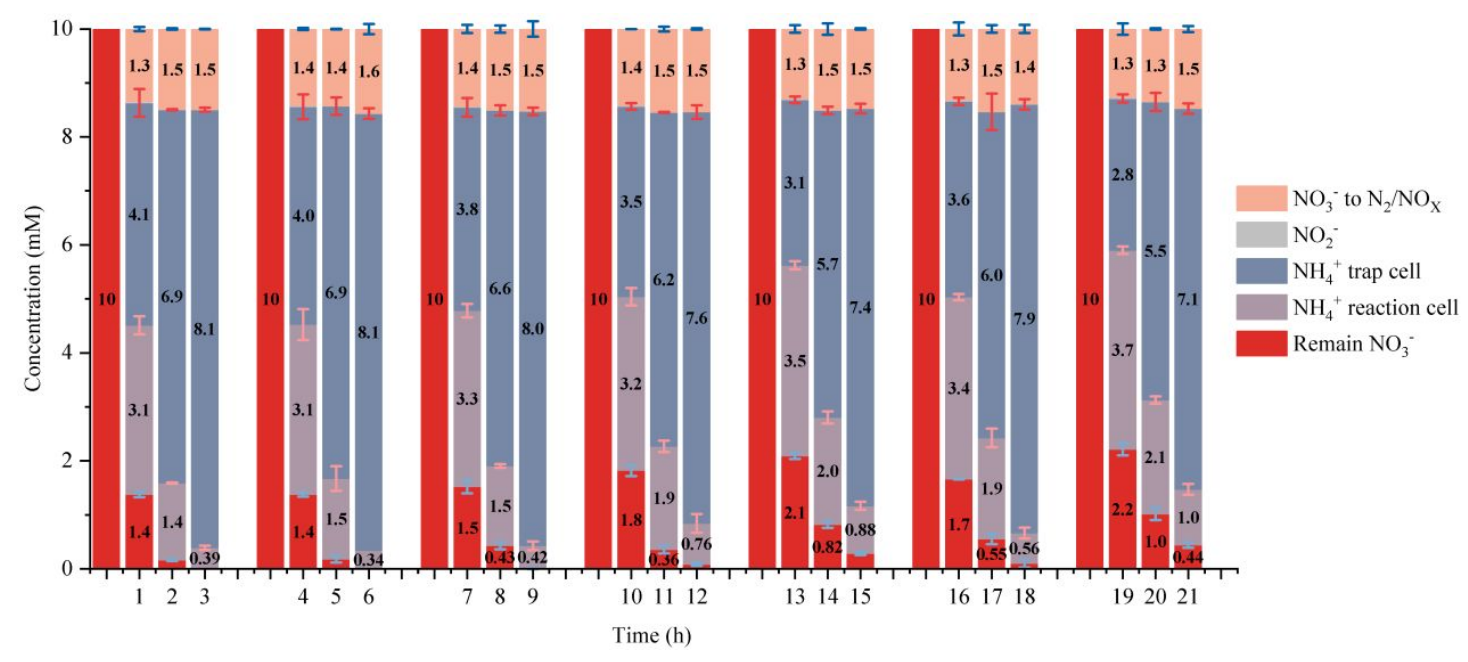

479 Figure S36. The recycle experiments of CoP fabricated ENRRA reactor. Basic testing conditions were 480 the same as Figure S4. Specific testing conditions: $\mathrm{Cl}^{-}, 0 \mathrm{mg} \mathrm{L}-1 ; \mathrm{pH}, \sim 7.0$; applied potential, $-2.4 \mathrm{~V}$

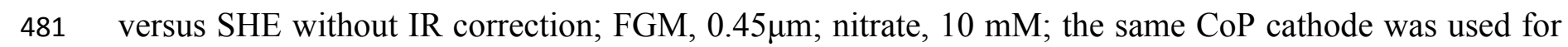
$482 \quad 21 \mathrm{~h}$ without changing. 


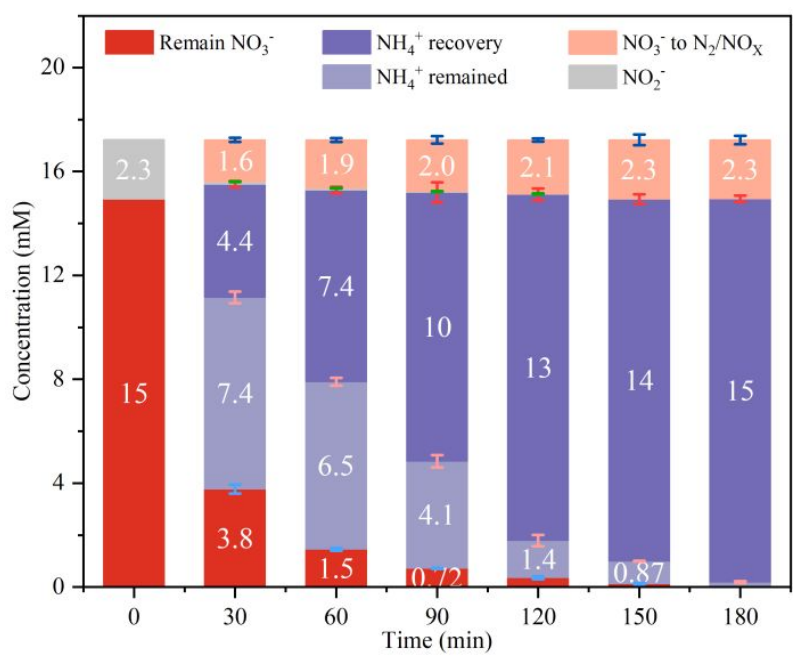

484 Figure S37. The treatment of actual printing wastewater. Basic testing conditions were the same as Figure 485 S4. Specific testing conditions: applied potential, $-2.4 \mathrm{~V}$ versus SHE without IR correction; FGM, $4860.45 \mu \mathrm{m}$. Actual printing wastewater: $14.9 \mathrm{mM} \mathrm{NO}_{3}^{-}, 2.3 \mathrm{mM} \mathrm{NO}_{2}^{-}, 0 \mathrm{mM} \mathrm{NH}{ }_{3} \mathrm{NH}_{4}^{+}, 5680 \mathrm{mg} \mathrm{L}^{-1} \mathrm{Cl}^{-}$, $487264 \mathrm{mg} \mathrm{L}^{-1} \mathrm{SO}_{4}^{-}, 400 \mathrm{mg} \mathrm{L}{ }^{-1} \mathrm{COD}, 5680 \mathrm{mg} \mathrm{L}^{-1} \mathrm{Cl}^{-}, 243 \mathrm{mg} \mathrm{L}^{-1} \mathrm{Na}^{+}$and $47 \mathrm{mg} \mathrm{L}^{-1} \mathrm{~K}^{+}$, pH 2.9. 


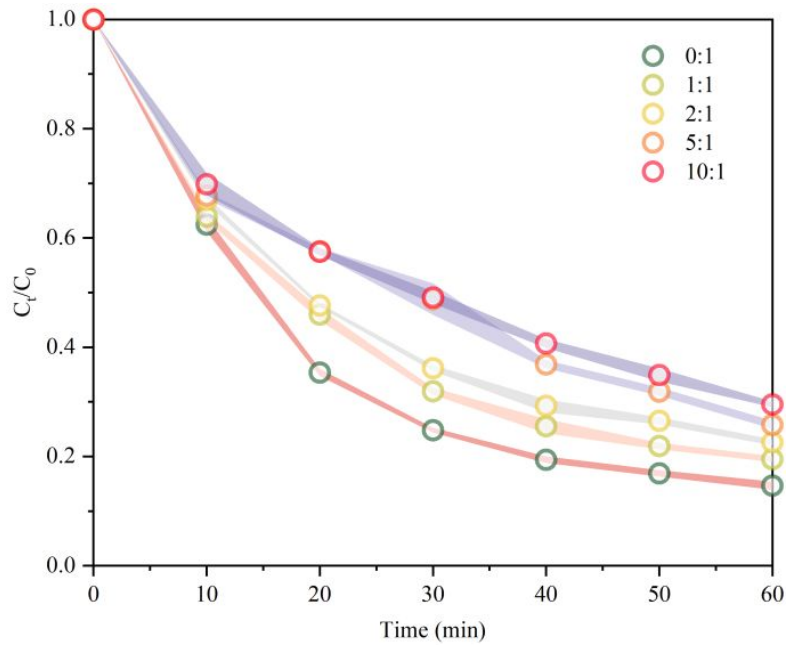

490 Figure S38. Nitrate reduction experiments with different $\mathrm{t}-\mathrm{BuOH} /$ nitrate ratios. Basic testing conditions 491 were the same as Figure $\mathrm{S} 4$. Specific testing conditions: $\mathrm{Cl}^{-}, 0 \mathrm{mg} \mathrm{L}{ }^{-1} ; \mathrm{pH}, \sim 7.0$; applied potential, -2.4 $492 \mathrm{~V}$ versus SHE without IR correction; FGM, $0.45 \mu \mathrm{m}$; nitrate, $10 \mathrm{mM}$; the t-BuOH concentrations were 493 from 0 to $100 \mathrm{mM}$. 


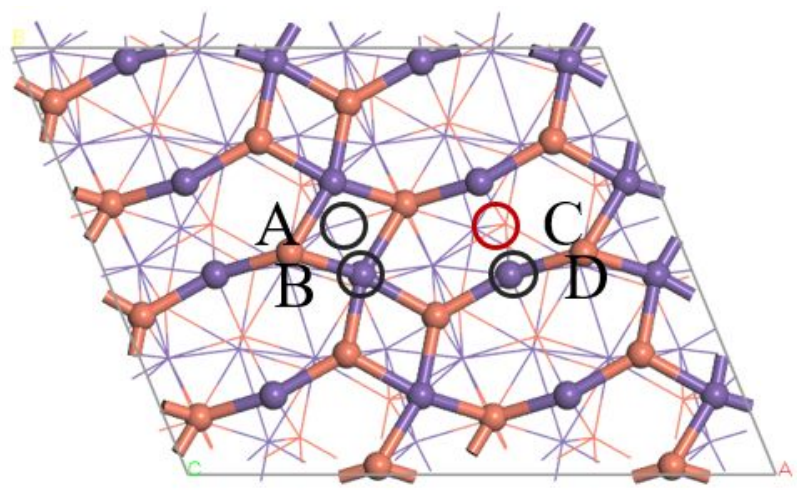

496 Figure S39. The adsorption of nitrate and $\mathrm{H}$ at different sites on the CoP (211) crystal plane. Detail of 497 adsorption free energy for different sites are listed in Table S4. 


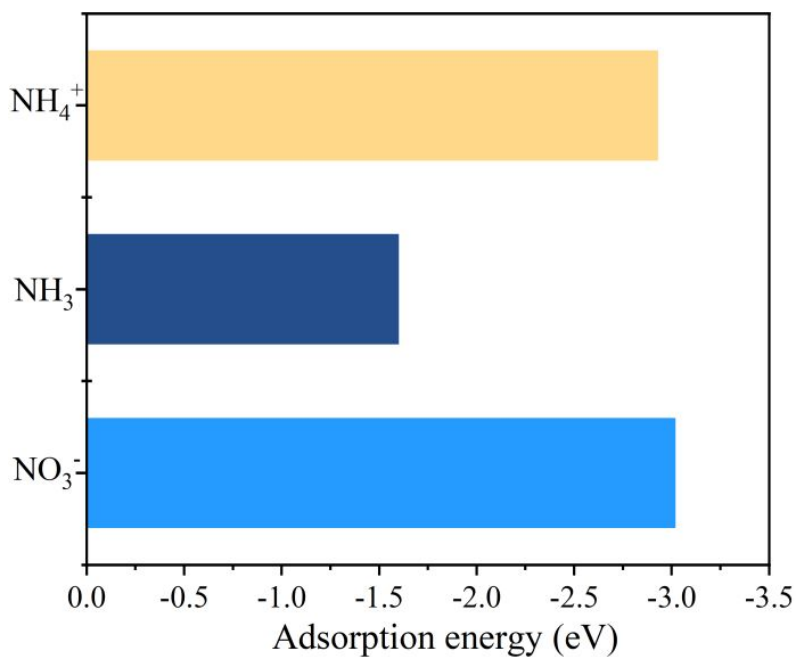

499 Figure S40. The adsorption energy of different nitrogen species on CoP (211). 


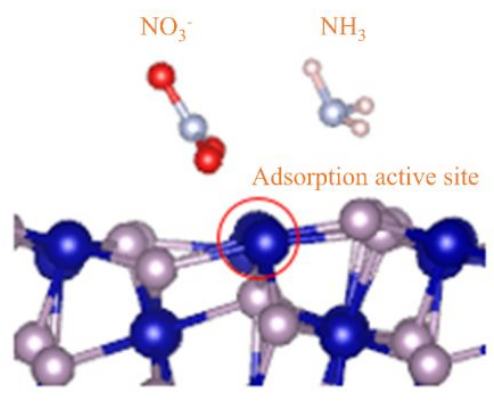

$\operatorname{CoP}(211)$

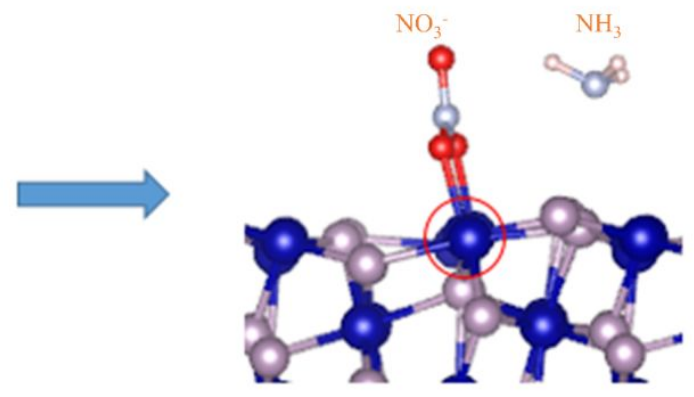

$\mathrm{CoP}(211)$

501 Figure S41. Structures before and after optimization for $\mathrm{NO}_{3}{ }^{-}$and $\mathrm{NH}_{3}$ on $\mathrm{CoP}(211)$. 


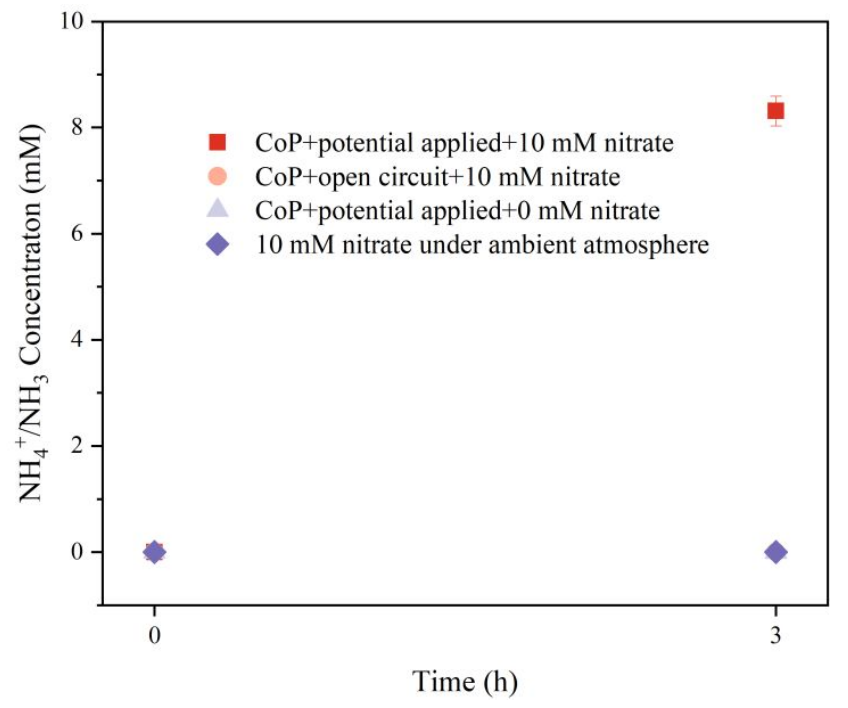

503 Figure S42. All the electrochemical operations were carried out under ambient atmosphere. To evaluate 504 possible interferences from any contaminants, we have carefully checked the $\mathrm{N}$ source of the generated $505 \mathrm{NH}_{3}$. No $\mathrm{NH}_{3}$ could be detected in catholytes at the beginning or ending of electrolysis without the 506 presence of $\mathrm{NO}_{3}^{-}$or potential applying, confirming that the detected $\mathrm{NH}_{3}$ was produced by 507 electroreduction of $\mathrm{NO}_{3}{ }^{-}$at the cathode surface. 


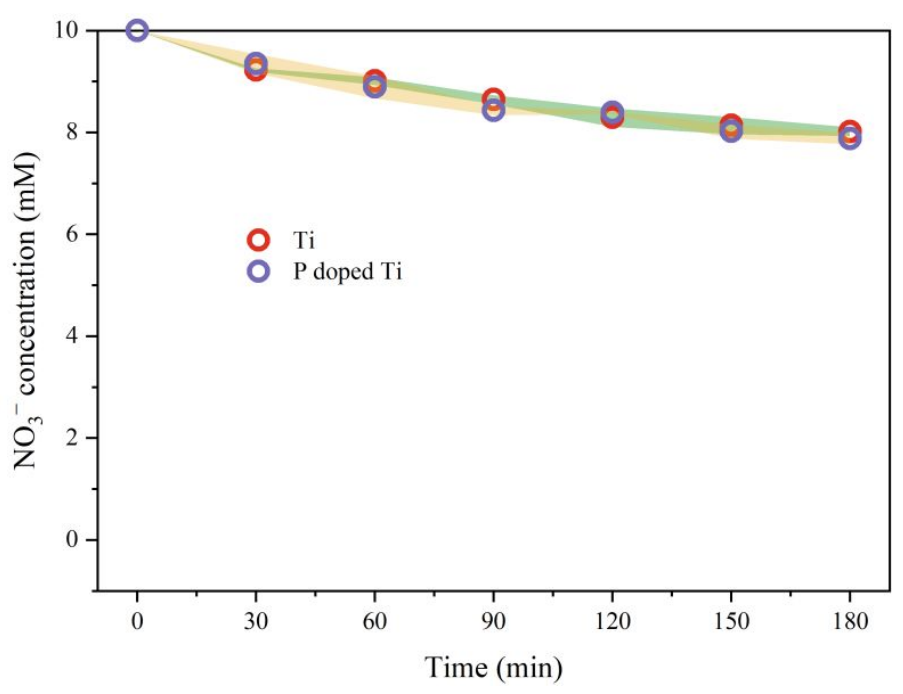

510 Figure $\mathrm{S} 43 . \mathrm{NO}_{3}^{-}-\mathrm{N}$ concentration decay kinetics during electrolysis time. Performance analysis under a 511 potential of $-2.4 \mathrm{~V}$ versus SHE without IR correction. Basic testing conditions: aqueous solution volume, $512100 \mathrm{~mL}$ of $\mathrm{NO}_{3}{ }^{-}$containing wastewater recycling in reactor chamber, $100 \mathrm{~mL}$ of $1 \mathrm{M} \mathrm{H}_{2} \mathrm{SO}_{4}$ recycling in 513 recovery chamber; $\mathrm{Na}_{2} \mathrm{SO}_{4}$ concentration, $0.1 \mathrm{M}$; cathode size in reaction, $16 \mathrm{~cm}^{2}$, various cathodes; 514 catalyst dosage, $0.8 \mathrm{mg} \mathrm{cm}{ }^{-2} \times 16 \mathrm{~cm}^{2}=12.8 \mathrm{mg}$; anode size in reaction, $16 \mathrm{~cm}^{2}, \mathrm{IrO}_{2}-\mathrm{RuO}_{2} / \mathrm{Ti}$; electrode 515 gap, $2.0 \mathrm{~cm}$; reference electrode, $\mathrm{SCE}$; temperature, $\sim 25^{\circ} \mathrm{C}$; circulation flow rate, $100 \mathrm{~mL} \mathrm{~min}{ }^{-1}$; FGM, $5160.45 \mu \mathrm{m}$; reaction time, 3.0 h. Specific testing conditions: $\mathrm{NO}_{3}^{-}$concentration, $10 \mathrm{mM} ; \mathrm{pH}, \sim 7.0 ; \mathrm{Cl}^{-}, 0$ $517 \quad \mathrm{mg} \mathrm{L}^{-1}$. 


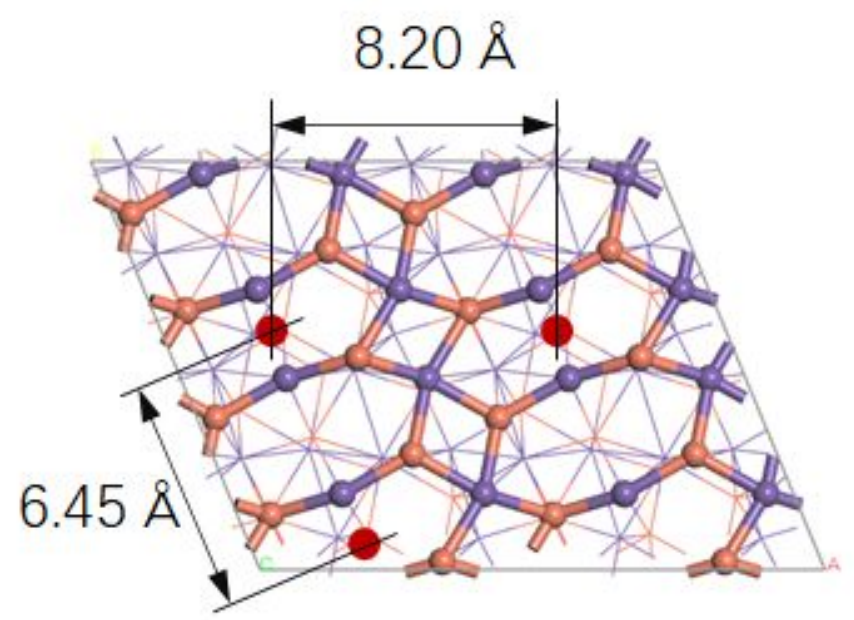

520 Figure S44. The distance of nearby active sites. 


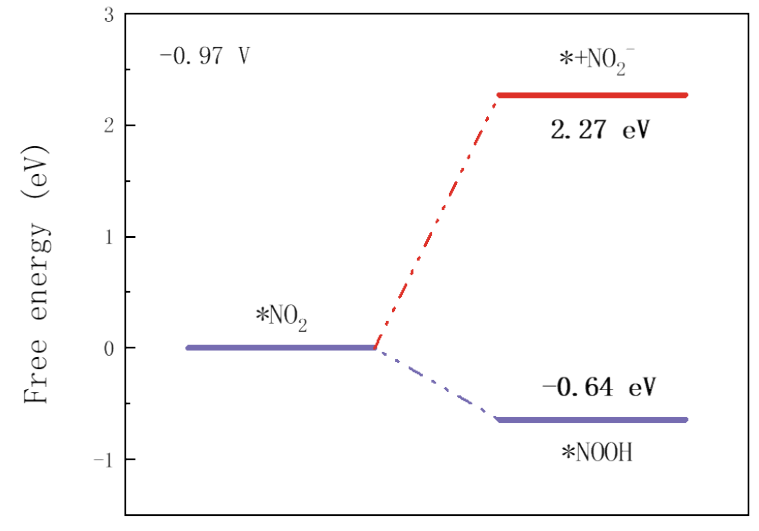

Reaction coordinate

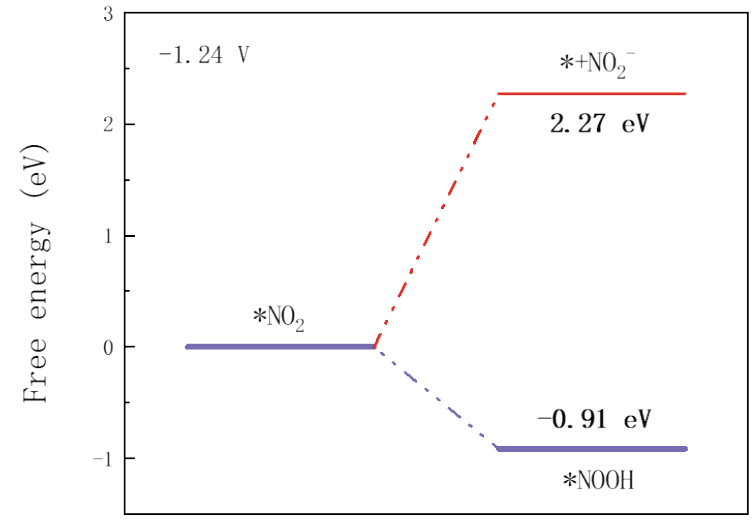

Reaction coordinate

522 Figure $\mathrm{S} 45$. The relative energy for $* \mathrm{NO}_{2}$ desorption and reduction at $-0.97 \mathrm{~V}$ and $-1.24 \mathrm{~V}$. 
(a)

Measured voltage

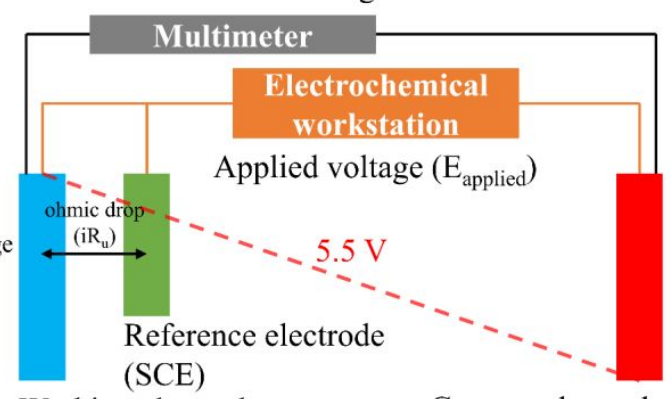

Working electrode (cathode)

(c)

Applied voltage is $7.0 \mathrm{~V}$

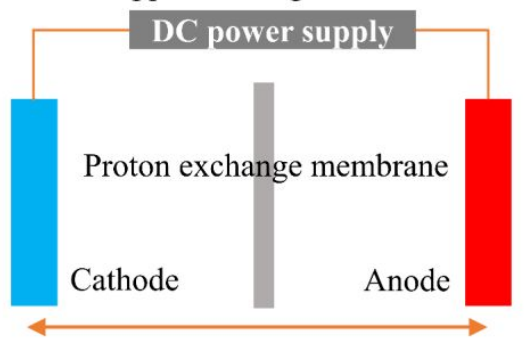

Distance between cathode and anode reduced to $\approx 6 \mathrm{~mm}$ owing to the remove of SCE (b)

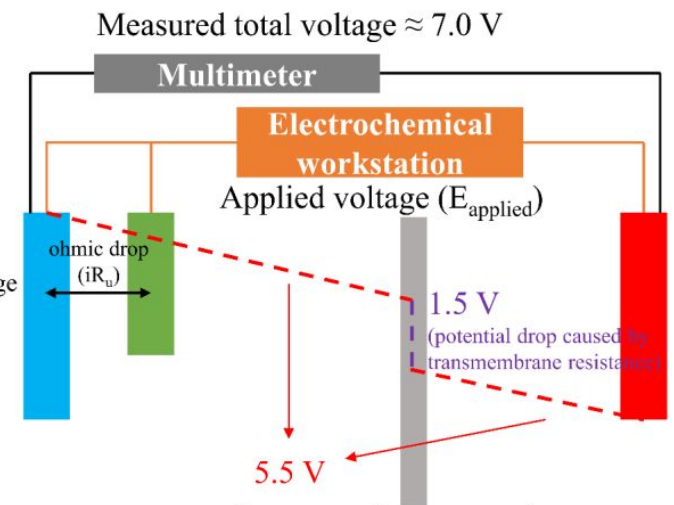

Proton exchange membrane

Distance between working and counter electrode $\approx 15 \mathrm{~mm}$

525 Figure S46. The schematic diagram of three electrode and two electrode operations. 


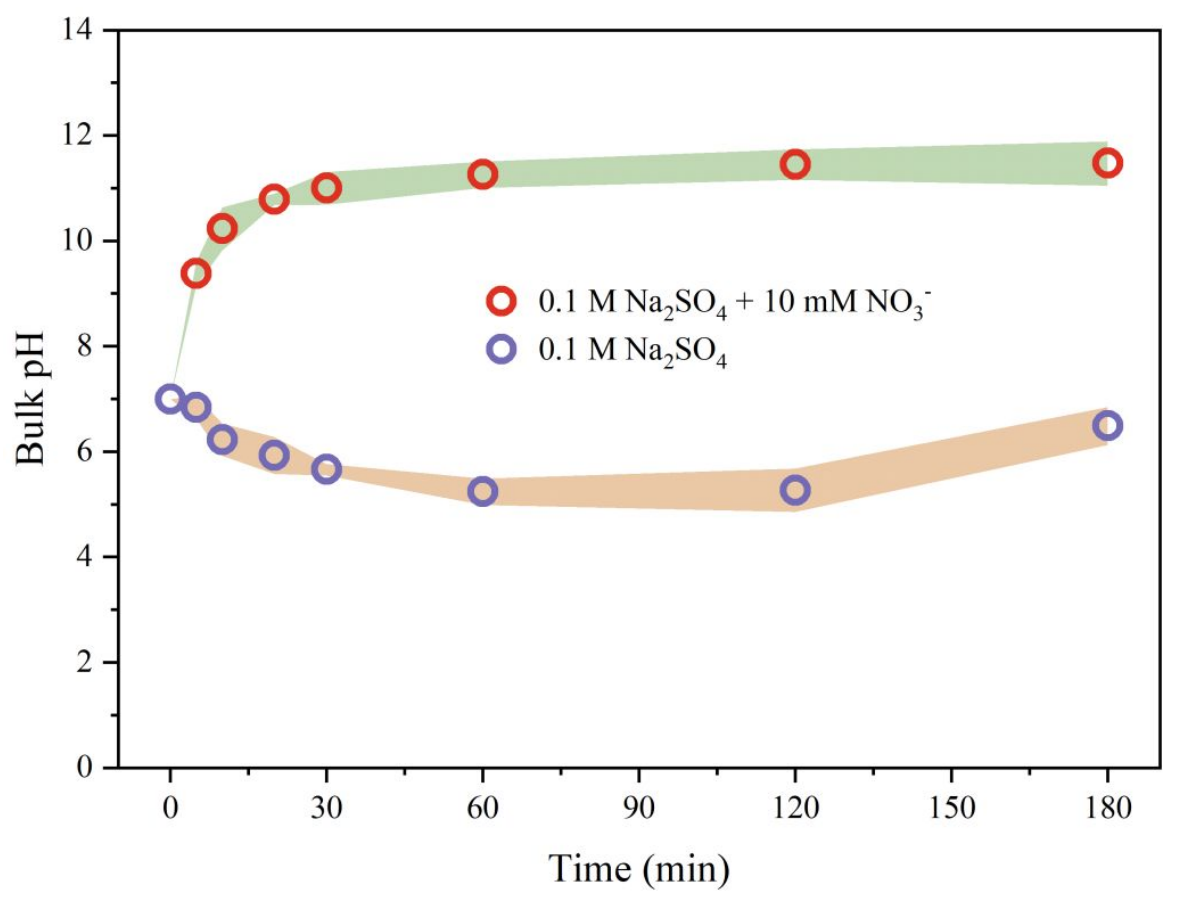

527 Figure $\mathrm{S} 47$. The compare of bulk $\mathrm{pH}$ with and without $\mathrm{NO}_{3}{ }^{-}$. 
529 Figure $\mathrm{S} 48 . \mathrm{NO}_{2}{ }^{-}$formation pathways. 


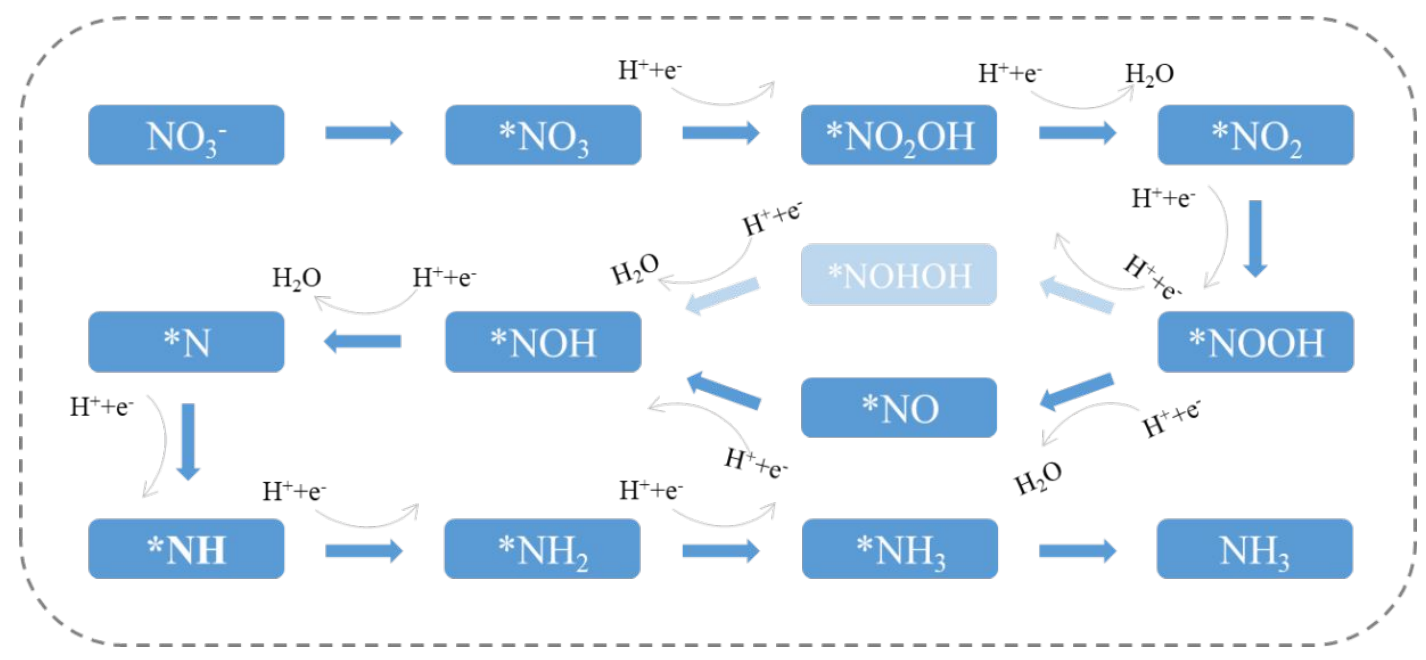

531 Figure $\mathrm{S} 49 . \mathrm{NH}_{3}$ formation pathways. 


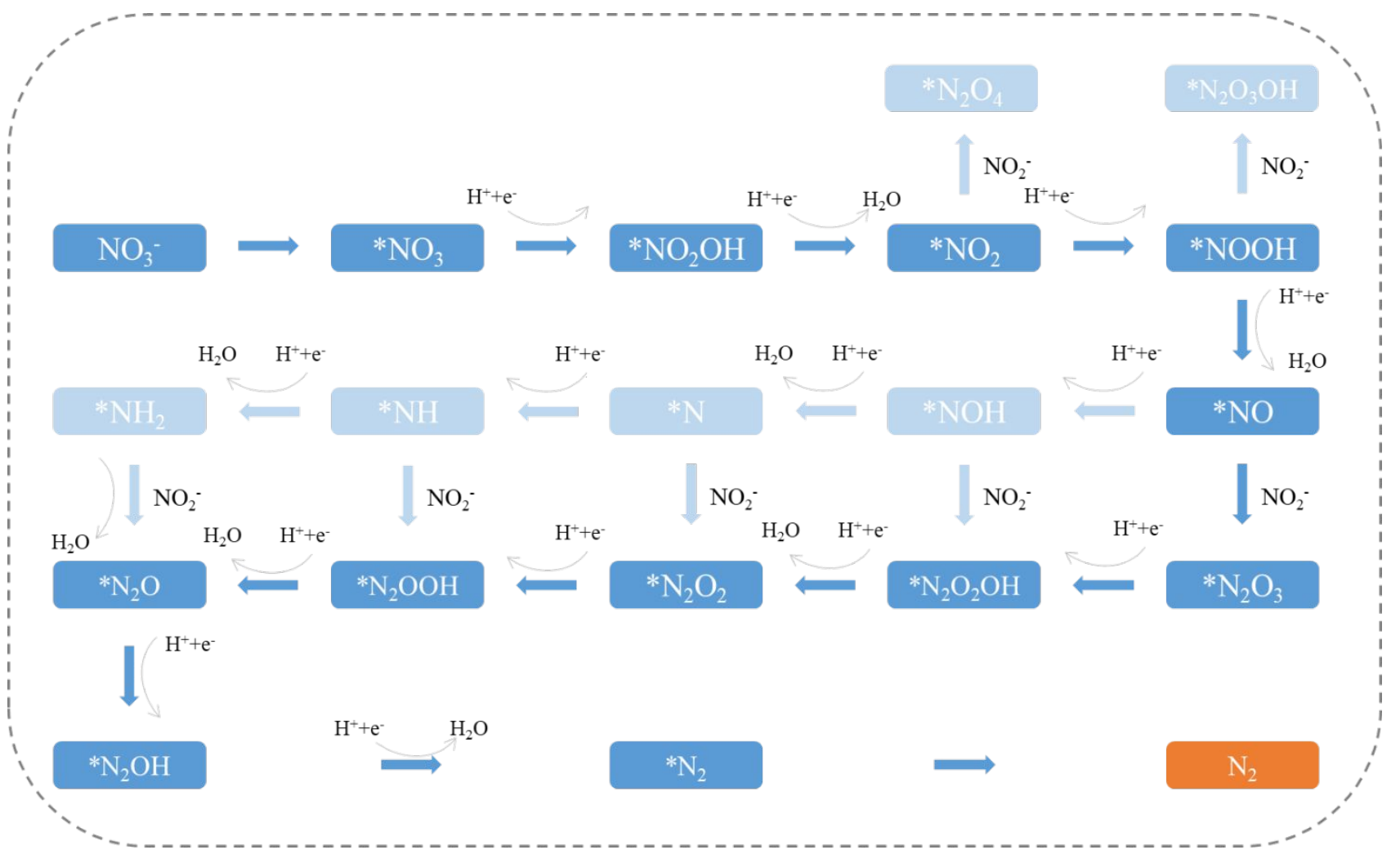

533 Figure S50. $\mathrm{N}_{2}$ formation pathways. 
Table S1. Comparison of the $\mathrm{NO}_{3}^{-}$reduction, $\mathrm{NH}_{3}$ recovery, and $\mathrm{NH}_{3}$ production rate of CoP cathode based ENRRA reactor with other catalysts/methods under ambient conditions ${ }^{17}$.

ENRRA $^{\text {a }}$ represents electrocatalytic nitrate reduction and recovery towards ammonia

ENRA $^{b}$ represents electrocatalytic nitrate reduction

$\mathrm{NRR}^{\mathrm{c}}$ represents electrochemical nitrogen reduction reaction.

d. Ammonia recovery calculation is based on the ration of recovered ammonia/ammonium to ammonia/ammonium produced/containing.

\begin{tabular}{|c|c|c|c|c|c|c|c|}
\hline Catalyst & Method & $\begin{array}{l}\mathrm{NO}_{3}^{-} \\
\text {removal }\end{array}$ & $\begin{array}{l}\mathrm{NH}_{3} \\
\text { recovery }\end{array}$ & $\begin{array}{l}\mathrm{NH}_{3} \text { production } \\
\left(\mathrm{gNH}_{3}-\mathrm{N} \mathrm{m}^{-1} d^{-1}\right)\end{array}$ & $\begin{array}{l}\text { Selectivity } \\
\text { for } \mathrm{NH}_{3}\end{array}$ & $F E$ or $E C$ & Reference \\
\hline CoP & ENRRA $^{a}$ & all $100 \%$ & $\begin{array}{l}95.4 \%- \\
99.7 \%\end{array}$ & $\begin{array}{c}60-306 \\
\mathrm{gNH}_{3}-\mathrm{N} \mathrm{m}^{-1} \mathrm{~d}^{-1}\end{array}$ & $85 \%-89 \%$ & $\begin{array}{c}38 \%-76 \% \\
88-267 \\
\mathrm{kWh} \mathrm{kg}^{-1} \\
\mathrm{~N}\end{array}$ & This study \\
\hline PTCDA/Cu & ENRA & -- & 0 & $\begin{array}{c}105 \\
\mathrm{gNH}_{3}-\mathrm{N} \mathrm{m}^{-1} \mathrm{~d}^{-1}\end{array}$ & -- & $77 \%$ & $\begin{array}{l}\text { Nature Energy 2020, 5, 605- } \\
613\end{array}$ \\
\hline $\mathrm{TiO}_{2-\mathbf{x}}$ & ENRA & $95 \%$ & 0 & $\begin{array}{c}0.045 \\
\mathrm{mmol} \mathrm{h}^{-1} \mathrm{mg}^{-1}\end{array}$ & $87 \%$ & $85 \%$ & $\begin{array}{c}\text { ACS Catalysis 2020, } 10, \\
3533-3540\end{array}$ \\
\hline
\end{tabular}




\begin{tabular}{|c|c|c|c|c|c|c|c|}
\hline $\begin{array}{l}\mathrm{Pd}_{0.17} \mathrm{Cu}_{0.82} / \mathrm{SS} \\
\mathrm{Pd}_{0.27} \mathrm{Cu}_{0.73} / \mathrm{SS} \\
\mathbf{P d}_{0.49} \mathrm{Cu}_{0.51} / \mathrm{SS}\end{array}$ & ENRA & $\begin{array}{l}90 \%- \\
99 \%\end{array}$ & 0 & -- & $\begin{array}{l}60 \% \\
34 \% \\
50 \%\end{array}$ & -- & $\begin{array}{c}\text { Applied Catalysis B: } \\
\text { Environmental 2020, 273, } \\
119053\end{array}$ \\
\hline $\begin{array}{l}\mathrm{Pd}-\mathrm{In} / \mathrm{Ti}_{\mathrm{n}} \mathrm{O}_{2 \mathrm{n}-1} \\
\mathrm{Pd}-\mathrm{Cu} / \mathrm{Ti}_{\mathrm{n}} \mathrm{O}_{2 \mathrm{n}-1} \\
\mathrm{Pd}-\mathrm{Cu} / \mathrm{REM}\end{array}$ & ENRA & -- & 0 & -- & -- & $\begin{array}{l}19 \% \\
22 \% \\
2.3 \%\end{array}$ & $\begin{array}{c}\text { Environ. Sci. Technol. 2018, } \\
\text { 52, 9370-9379 }\end{array}$ \\
\hline $\mathbf{P d}-\mathrm{In} / \mathrm{c}-\mathrm{Al}_{2} \mathrm{O}_{3}$ & ENRA & -- & 0 & -- & -- & $71.5 \%$ & Catal. Lett. 2009, 130, 56-62 \\
\hline $\begin{array}{l}\mathbf{P t} \\
\mathrm{Cu}\end{array}$ & ENRA & -- & 0 & -- & -- & $\begin{array}{l}49 \% \\
6 \%\end{array}$ & $\begin{array}{c}\text { Chem. Commun. 2006, } 732- \\
734\end{array}$ \\
\hline $\mathrm{P}-\mathrm{Co}_{3} \mathrm{O}_{4} / \mathrm{NF}$ & ENRA & -- & 0 & $\begin{array}{c}35.3 \\
\mathrm{gNH}_{3}-\mathrm{N} \mathrm{m}^{-1} \mathrm{~d}^{-1}\end{array}$ & -- & -- & $\begin{array}{c}\text { Chem. Eng. J. } 382 \text { (2020) } \\
123034\end{array}$ \\
\hline $\mathrm{Co}_{3} \mathrm{O}_{4}-\mathrm{TiO}_{2} / \mathrm{Ti}$ & ENRA & $89 \%$ & 0 & $\begin{array}{c}30.8 \\
\mathrm{gNH}_{3}-\mathrm{N} \mathrm{m}^{-1} \mathrm{~d}^{-1}\end{array}$ & $81 \%$ & -- & $\begin{array}{l}\text { Applied Catalysis B: } \\
\text { Environmental 2019, 254, } \\
\text { 391-402 }\end{array}$ \\
\hline $\mathrm{Co}_{3} \mathrm{O}_{4} / \mathrm{Ti}$ & ENRA & $98 \%$ & 0 & $\begin{array}{c}13.5 \\
\mathrm{gNH}_{3}-\mathrm{N} \mathrm{m}^{-1} \mathrm{~d}^{-1}\end{array}$ & $70 \%$ & -- & Water Res. 2017, 120, 1-11 \\
\hline $\mathrm{Ni}-\mathrm{Fe}^{0} @ \mathrm{Fe}_{3} \mathrm{O}_{4}$ & ENRA & $90 \%$ & 0 & -- & $10.4 \%$ & -- & $\begin{array}{c}\text { Journal of Cleaner } \\
\text { Production 2020, 242, } \\
118569\end{array}$ \\
\hline Sn & ENRA & $99.5 \%$ & 0 & -- & $8.1 \%$ & -- & $\begin{array}{c}\text { Electrochim. Acta 2006, 52, } \\
1329-1338\end{array}$ \\
\hline
\end{tabular}




\begin{tabular}{|c|c|c|c|c|c|c|c|}
\hline Fe/Pd-R & ENRA & $95 \%$ & 0 & -- & $7 \%$ & -- & $\begin{array}{c}\text { Chem. Eng. J. 2016, 286, } \\
\text { 408-415 }\end{array}$ \\
\hline Zero-valent titanium & ENRA & $70 \%$ & 0 & -- & $6 \%$ & -- & $\begin{array}{c}\text { Water Res. 2019, 157, } 191- \\
200\end{array}$ \\
\hline Cu-Bi & ENRA & $87.5 \%$ & 0 & -- & $19 \%$ & -- & $\begin{array}{l}\text { J. Electroanal. Chem. 2018, } \\
\qquad 817,202-209\end{array}$ \\
\hline $\begin{array}{c}\text { Cu mesh } \\
\mathrm{Cu} \text { NWAs } \\
\mathrm{Cu} / \mathrm{Cu}_{2} \mathrm{O} \text { NWAs }\end{array}$ & ENRA & $\begin{array}{l}48 \% \\
52 \% \\
97 \%\end{array}$ & 0 & $\begin{array}{c}90 \\
168 \\
823 \\
\mathrm{gNH}_{3}-\mathrm{N} \mathrm{m}^{-1} \mathrm{~d}^{-1}\end{array}$ & $\begin{array}{l}18 \% \\
26 \% \\
81 \%\end{array}$ & $\begin{array}{l}40 \% \\
44 \% \\
96 \%\end{array}$ & $\begin{array}{c}\text { Angewandte Chemie 2020, } \\
13,5388-5392 .\end{array}$ \\
\hline $\mathrm{Pd}-\mathrm{Cu} / \mathrm{TiO}_{2}$ & NRR & -- & 0 & $\mathrm{mmol} \mathrm{g}_{\text {cat }}^{-1} \mathrm{~h}^{-1}$ & -- & $8.9 \%$ & $\begin{array}{c}\text { Nature Chemistry 2020, } 12 \text {, } \\
\text { 717-724 }\end{array}$ \\
\hline MXene/TiFeO & NRR & -- & 0 & $\mathrm{mmol} \mathrm{g}_{\text {cat }}{ }^{-1} \mathrm{~h}^{-1}$ & -- & $25 \%$ & $\begin{array}{c}\text { ACS Nano 2020, 14, 9089- } \\
9097\end{array}$ \\
\hline Au nanorods & NRR & -- & 0 & $\operatorname{mmol~g}_{\text {cat }}^{-1} \mathrm{~h}^{-1}$ & -- & $4.02 \%$ & $\begin{array}{c}\text { Adv. Mater. 2017, 29, } \\
1604799\end{array}$ \\
\hline $\mathrm{Pd} / \mathrm{Cu} / \mathrm{rGO}$ & NRR & -- & 0 & $\mathrm{mmol} \mathrm{g}_{\text {cat }}^{-1} \mathrm{~h}^{-1}$ & -- & $4.3 \%$ & $\begin{array}{c}\text { Advanced Energy Materials } \\
2018,8,1800124\end{array}$ \\
\hline Rh nanosheets & NRR & -- & 0 & $\mathrm{mmol} \mathrm{g}_{\text {cat }}{ }^{-1} \mathrm{~h}^{-1}$ & -- & $0.2 \%$ & $\begin{array}{c}\text { Journal of Materials } \\
\text { Chemistry A 2018, 6, 3211- } \\
3217\end{array}$ \\
\hline
\end{tabular}




\begin{tabular}{|c|c|c|c|c|c|c|c|}
\hline $\mathrm{CeO}_{2}$ nanorods & NRR & -- & 0 & $\mathrm{mmol} \mathrm{g}_{\mathrm{cat}}^{-1} \mathrm{~h}^{-1}$ & -- & $3.7 \%$ & $\begin{array}{c}\text { ACS Sustainable Chemistry } \\
\text { \& Engineering 2018, 6, } \\
9550-9554\end{array}$ \\
\hline $\mathrm{Fe}-\mathrm{TiO}_{2}$ nanoparticles & NRR & -- & 0 & $\begin{array}{c}5.1 \\
\mathrm{gNH}_{3}-\mathrm{N} \mathrm{m}^{-2} \mathrm{~d}^{-1}\end{array}$ & -- & $25.6 \%$ & $\begin{array}{c}\text { Angew. Chem. Int. Ed. } 2019, \\
58,18449\end{array}$ \\
\hline $\mathrm{CoS} @ \mathrm{TiO}_{2}$ & NRR & -- & 0 & $\begin{array}{c}9.8 \\
\mathrm{gNH}_{3}-\mathrm{N} \mathrm{m}^{-2} \mathrm{~d}^{-1}\end{array}$ & -- & $28.6 \%$ & $\begin{array}{c}\text { Angew. Chem. Int. Ed. } 2019, \\
58,18903\end{array}$ \\
\hline $\mathrm{CoS}_{2} / \mathrm{NS}-\mathrm{G}$ & NRR & -- & 0 & $\begin{array}{c}5.0 \\
\mathrm{gNH}_{3}-\mathrm{N} \mathrm{m}^{-2} \mathrm{~d}^{-1}\end{array}$ & -- & $25.9 \%$ & $\begin{array}{c}\text { Proc. Natl. Acad. Sci. USA } \\
2019,116,6635\end{array}$ \\
\hline $\mathrm{MoS}_{2} @$ RGO & NRR & -- & 0 & $\begin{array}{c}5.0 \\
\mathrm{gNH}_{3}-\mathrm{N} \mathrm{m}^{-2} \mathrm{~d}^{-1}\end{array}$ & -- & $4.6 \%$ & $\begin{array}{l}\text { J. Mater. Chem. A 2019, 7, } \\
\qquad 2524\end{array}$ \\
\hline $\mathrm{Au}-\mathrm{Fe}_{3} \mathrm{O}_{4}$ & NRR & -- & 0 & $\begin{array}{c}2.2 \\
\mathrm{gNH}_{3}-\mathrm{N} \mathrm{m}^{-2} \mathrm{~d}^{-1}\end{array}$ & -- & $10.5 \%$ & $\begin{array}{c}\text { Adv. Funct. Mater. 2019, } \\
1906579\end{array}$ \\
\hline Fe3S4 $^{18}$ & NRR & -- & 0 & $\begin{array}{c}5.4 \\
\mathrm{mmol} \mathrm{g}_{\mathrm{cat}}^{-1} \mathrm{~h}^{-1}\end{array}$ & -- & $6.5 \%$ & $\begin{array}{c}\text { Chem. Commun. 2018, 54, } \\
\text { 13010-13013 }\end{array}$ \\
\hline Bi NS & NRR & -- & 0 & $\begin{array}{c}0.9 \\
\text { mmol g }_{\text {cat }}^{-1} \mathrm{~h}^{-1}\end{array}$ & -- & $10.5 \%$ & ACS Catal. 2019, 9, 2902 \\
\hline$\alpha-\mathrm{Fe}_{2} \mathrm{O}_{3}$ nanocubes & NRR & -- & 0 & $\begin{array}{c}2.3 \\
\mathrm{mmol} \mathrm{g}_{\mathrm{cat}}^{-1} \mathrm{~h}^{-1}\end{array}$ & -- & $6.6 \%$ & $\begin{array}{c}\text { Chem. Commun. 2019, 55, } \\
7370\end{array}$ \\
\hline
\end{tabular}




\begin{tabular}{|c|c|c|c|c|c|c|c|}
\hline BC & NRR & -- & 0 & $\begin{array}{c}0.6 \\
\mathrm{gNH}_{3}-\mathrm{N} \mathrm{m}^{-2} \mathrm{~d}^{-1}\end{array}$ & -- & $16.0 \%$ & Nat. Commun. 2018, 9, 3485 \\
\hline $\mathrm{MoO}_{2}$ nanosheets & NRR & -- & 0 & $\begin{array}{c}0.9 \\
\mathrm{mmol} \mathrm{g}_{\mathrm{cat}}^{-1} \mathrm{~h}^{-1}\end{array}$ & -- & $8.2 \%$ & Nano Energy 2019, 59, 10 \\
\hline $\mathbf{P d} / \mathrm{C}$ & NRR & -- & 0 & $\begin{array}{c}0.3 \\
\mathrm{mmol} \mathrm{g}_{\mathrm{cat}}^{-1} \mathrm{~h}^{-1}\end{array}$ & -- & $8.2 \%$ & Nat. Commun. 2018, 9, 1795 \\
\hline Au nanorod & NRR & -- & 0 & $\begin{array}{c}0.4 \\
\mathrm{mmol} \mathrm{g}_{\mathrm{cat}}^{-1} \mathrm{~h}^{-1}\end{array}$ & -- & $3.9 \%$ & $\begin{array}{c}\text { Adv. Mater. } 2017,29 \\
1604799\end{array}$ \\
\hline Defect-rich $\mathrm{MoS}_{2}$ & NRR & -- & 0 & $\begin{array}{c}2.1 \\
\mathrm{mmol} \mathrm{g}_{\mathrm{cat}}^{-1} \mathrm{~h}^{-1}\end{array}$ & -- & $8.3 \%$ & $\begin{array}{c}\text { Adv. Energy Mater. 2018, 8, } \\
1801357\end{array}$ \\
\hline $\mathbf{R u} / \mathbf{M o S}_{2}$ & NRR & -- & 0 & $\begin{array}{c}0.5 \\
\mathrm{mmol} \mathrm{g}_{\mathrm{cat}}{ }^{-1} \mathrm{~h}^{-1}\end{array}$ & -- & $17.6 \%$ & $\begin{array}{l}\text { ACS Energy Lett. 2019, 4, } \\
430\end{array}$ \\
\hline Ru nanoparticle & NRR & -- & 0 & $\begin{array}{c}0.1 \\
\mathrm{gNH}_{3}-\mathrm{N} \mathrm{m}^{-2} \mathrm{~d}^{-1}\end{array}$ & -- & $5.4 \%$ & $\begin{array}{c}\text { ChemSusChem 2018, 11, } \\
3416\end{array}$ \\
\hline $\mathbf{M o S}_{2}$ & NRR & -- & 0 & $\begin{array}{c}1.3 \\
\mathrm{gNH}_{3}-\mathrm{N} \mathrm{m}^{-2} \mathrm{~d}^{-1}\end{array}$ & -- & $1.2 \%$ & $\begin{array}{c}\text { Adv. Mater. } 2018,30, \\
1800191\end{array}$ \\
\hline VN nanoparticles & NRR & -- & 0 & $\begin{array}{c}4.9 \\
\mathrm{gNH}_{3}-\mathrm{N} \mathrm{m}^{-2} \mathrm{~d}^{-1}\end{array}$ & -- & $6.5 \%$ & $\begin{array}{c}\text { J. Am. Chem. Soc. 2018, } \\
\text { 140, } 13387\end{array}$ \\
\hline
\end{tabular}




\begin{tabular}{|c|c|c|c|c|c|c|c|}
\hline $\mathrm{BiVO}_{4}$ & NRR & -- & 0 & $\begin{array}{c}0.6 \\
\mathrm{mmol} \mathrm{g}_{\mathrm{cat}}^{-1} \mathrm{~h}^{-1}\end{array}$ & -- & $10.0 \%$ & $\begin{array}{l}\text { Small Methods 2018, 3, } \\
1800333\end{array}$ \\
\hline ISAS-Fe/NC & NRR & -- & 0 & $\operatorname{mmol~g}_{\text {cat }}^{-1} h^{-1}$ & -- & $18.6 \%$ & Nano Energy 2019, 61, 420 \\
\hline Au-PTFE/TS & NRR & -- & 0 & $\begin{array}{l}\quad 4.5 \\
\mathrm{gNH}_{3}-\mathrm{N} \mathrm{m}^{-2} \mathrm{~d}^{-1}\end{array}$ & -- & $37.8 \%$ & Chem 2019, 5, 617 \\
\hline Defect-rich fluorographene & NRR & -- & 0 & $\mathrm{mmol} \mathrm{g}_{\text {cat }}^{-1} \mathrm{~h}^{-1}$ & -- & $4.2 \%$ & $\begin{array}{l}\text { Chem. Commun. 2019, 55, } \\
4266\end{array}$ \\
\hline Fe-phthalocyanine & NRR & -- & 0 & $\begin{array}{l}8.2 \\
\mathrm{gNH}_{3}-\mathrm{N} \mathrm{m}^{-2} \mathrm{~d}^{-1}\end{array}$ & -- & $0.4 \%$ & $\begin{array}{c}\text { J. Electroanal. Chem. 1989, } \\
\text { 263, } 171\end{array}$ \\
\hline $30 \%-\mathrm{Fe}_{2} \mathrm{O}_{3}-\mathrm{CNT}$ & NRR & -- & 0 & $\begin{array}{l}0.1 \\
\mathrm{gNH}_{3}-\mathrm{N} \mathrm{m}^{-2} \mathrm{~d}^{-1}\end{array}$ & -- & $0.03 \%$ & $\begin{array}{c}\text { ACS Sustainable Chem. Eng. } \\
\text { 2017, 5, } 7393\end{array}$ \\
\hline MOF-derived N-doped & NRR & -- & 0 & $\begin{array}{c}13.8 \\
\mathrm{gNH}_{3}-\mathrm{N} \mathrm{m}^{-2} \mathrm{~d}^{-1}\end{array}$ & -- & $10.2 \%$ & Nano Energy 2018, 8, 17 \\
\hline Fe-N/C-CNTs & NRR & -- & 0 & $\mathrm{mmol} \mathrm{g}_{\text {cat }}{ }^{-1} \mathrm{~h}^{-1}$ & -- & $9.3 \%$ & ACS Catal. 2019, 9, 336 \\
\hline
\end{tabular}




\begin{tabular}{|c|c|c|c|c|c|c|c|}
\hline SA-Mo/NPC & NRR & -- & 0 & $\begin{array}{c}2.4 \\
\mathrm{mmol} \mathrm{g}_{\mathrm{cat}}^{-1} \mathrm{~h}^{-1}\end{array}$ & -- & $14.6 \%$ & $\begin{array}{c}\text { Angew. Chem. Int. Ed. } 2018 \text {, } \\
58,2321\end{array}$ \\
\hline (110)-oriented Mo nanofilm & NRR & -- & 0 & $\begin{array}{c}0.1 \\
\mathrm{mmol} \mathrm{g}_{\mathrm{cat}}{ }^{-1} \mathrm{~h}^{-1}\end{array}$ & -- & $0.7 \%$ & $\begin{array}{c}\text { J. Mater. Chem. A 2017, 5, } \\
18967\end{array}$ \\
\hline Rh NNs & NRR & -- & 0 & $\begin{array}{c}1.7 \\
\mathrm{mmol} \mathrm{g} \\
\mathrm{cat}^{-1} \mathrm{~h}^{-1}\end{array}$ & -- & $0.2 \%$ & $\begin{array}{l}\text { J. Mater. Chem. A 2018, 6, } \\
3211\end{array}$ \\
\hline $\mathbf{P d}_{0.2} \mathrm{Cu}_{0.8} / \mathrm{rGO}$ & NRR & -- & 0 & $\begin{array}{c}0.2 \\
\mathrm{mmol} \mathrm{g}_{\mathrm{cat}}^{-1} \mathrm{~h}^{-1}\end{array}$ & -- & $\sim 4.5 \%$ & $\begin{array}{c}\text { Adv. Energy Mater. 2018, 8, } \\
1800124\end{array}$ \\
\hline $\mathrm{OV}$-enriched $\mathrm{Fe}_{2} \mathrm{O}_{3} / \mathrm{CNT}$ & NRR & -- & 0 & $\begin{array}{c}0.1 \\
\mathrm{gNH}_{3}-\mathrm{N} \mathrm{m}^{-2} \mathrm{~d}^{-1}\end{array}$ & -- & $6.0 \%$ & $\begin{array}{c}\text { Chem. Eur. J. 2018, 24, } \\
18494\end{array}$ \\
\hline $\mathrm{Fe}_{2} \mathrm{O}_{3}-\mathrm{CNT}$ & NRR & -- & 0 & $\begin{array}{c}0.1 \\
\mathrm{gNH}_{3}-\mathrm{N} \mathrm{m}^{-2} \mathrm{~d}^{-1}\end{array}$ & -- & $4.9 \%$ & $\begin{array}{c}\text { Angew Chem. Int. Ed. } 2017 \text {, } \\
56,2699\end{array}$ \\
\hline $\mathrm{Ru} @ \mathrm{ZrO}_{2} / \mathrm{NC}$ & NRR & -- & 0 & $\begin{array}{c}0.3 \\
\mathrm{mmol} \mathrm{g}_{\mathrm{cat}}^{-1} \mathrm{~h}^{-1}\end{array}$ & -- & $\sim 15 \%$ & Chem 2018, 5, 204 \\
\hline $\mathrm{Mo}_{2} \mathrm{C}$ nanorod & NRR & -- & 0 & $\begin{array}{c}6.8 \\
\mathrm{mmol} \mathrm{g}_{\mathrm{cat}}^{-1} \mathrm{~h}^{-1}\end{array}$ & -- & $8.1 \%$ & ACS Cent. Sci. 2019, 5, 116 \\
\hline $\mathrm{Mo}_{2} \mathrm{~N}$ nanorod & NRR & -- & 0 & $\begin{array}{c}5.6 \\
\mathrm{mmol} \mathrm{g}_{\text {cat }}^{-1} \mathrm{~h}^{-1}\end{array}$ & -- & $4.5 \%$ & $\begin{array}{l}\text { Chem. Commun. 2018, } \\
54,8474\end{array}$ \\
\hline
\end{tabular}




\begin{tabular}{|c|c|c|c|c|c|c|c|}
\hline $\mathrm{NbO}_{2}$ nanoparticles & NRR & -- & 0 & $\begin{array}{c}2.3 \\
\mathrm{gNH}_{3}-\mathrm{N} \mathrm{m}^{-2} \mathrm{~d}^{-1}\end{array}$ & -- & $32 \%$ & $\begin{array}{c}\text { Small Methods 2018, } 3 \text {, } \\
1800386\end{array}$ \\
\hline $\mathrm{Nb}_{2} \mathrm{O}_{5}$ nanofiber & NRR & -- & 0 & $\begin{array}{c}8.6 \\
\mathrm{gNH}_{3}-\mathrm{N} \mathrm{m}^{-2} \mathrm{~d}^{-1}\end{array}$ & -- & $9.3 \%$ & Nano Energy 2018, 52, 264 \\
\hline $\mathrm{Nb}_{3} \mathrm{O}_{7}(\mathrm{OH}) / \mathrm{CFC}$ & NRR & -- & 0 & $\begin{array}{c}3.6 \\
\mathrm{gNH}_{3}-\mathrm{N} \mathrm{m}^{-2} \mathrm{~d}^{-1}\end{array}$ & -- & $39.9 \%$ & $\begin{array}{c}\text { J. Mater. Chem. A 2019, 7, } \\
16969\end{array}$ \\
\hline $\mathrm{MoO}_{3}$ nanosheet & NRR & -- & 0 & $\begin{array}{c}5.8 \\
\mathrm{gNH}_{3}-\mathrm{N} \mathrm{m}^{-2} \mathrm{~d}^{-1}\end{array}$ & -- & $1.9 \%$ & $\begin{array}{c}\text { J. Mater. Chem. A 2018, 6, } \\
12974\end{array}$ \\
\hline $\mathrm{Cr}_{2} \mathrm{O}_{3}$ nanofiber & NRR & -- & 0 & $\begin{array}{c}2.0 \\
\mathrm{mmol} \mathrm{g}_{\text {cat }}{ }^{-1} \mathrm{~h}^{-1}\end{array}$ & -- & $8.6 \%$ & $\begin{array}{c}\text { Chem. Commun. 2018, 54, } \\
12848\end{array}$ \\
\hline $\mathrm{Bi}_{4} \mathrm{~V}_{2} \mathrm{O}_{11} / \mathrm{CeO}_{2}$ & NRR & -- & 0 & $\begin{array}{c}4.6 \\
\mathrm{gNH}_{3}-\mathrm{N} \mathrm{m}^{-2} \mathrm{~d}^{-1}\end{array}$ & -- & $10.2 \%$ & $\begin{array}{c}\text { Angew. Chem. Int. Ed. 2018, } \\
\text { 57, } 6073\end{array}$ \\
\hline $\begin{array}{c}\mathrm{Au} / \mathrm{TiO}_{2} \\
(1.542 \text { wt.\% Au) }\end{array}$ & NRR & -- & 0 & $\frac{1.5}{\mathrm{mmol} \mathrm{g}_{\mathrm{cat}}^{-1} \mathrm{~h}^{-1}}$ & -- & $8.1 \%$ & $\begin{array}{c}\text { Adv. Mater. 2017, } 29, \\
1606550\end{array}$ \\
\hline MoN NA/CC & NRR & -- & 0 & $\begin{array}{c}4.4 \\
\mathrm{gNH}_{3}-\mathrm{N} \mathrm{m}^{-2} \mathrm{~d}^{-1}\end{array}$ & -- & $1.2 \%$ & $\begin{array}{c}\text { ACS Sustainable Chem. Eng. } \\
2018,6,9550\end{array}$ \\
\hline NCF-900 & NRR & -- & 0 & $\begin{array}{c}1.1 \\
\mathrm{mmol} \mathrm{g}_{\mathrm{cat}}{ }^{-1} \mathrm{~h}^{-1}\end{array}$ & -- & $1.5 \%$ & $\begin{array}{l}\text { J. Mater. Chem. A 2018, 6, } \\
7762\end{array}$ \\
\hline
\end{tabular}




\begin{tabular}{|c|c|c|c|c|c|c|c|}
\hline Amorphous $\mathrm{Au} / \mathrm{CeO}_{\mathrm{x}}$ & NRR & -- & 0 & $\begin{array}{c}0.6 \\
\mathrm{mmol} \mathrm{g}_{\mathrm{cat}}^{-1} \mathrm{~h}^{-1}\end{array}$ & -- & $10.1 \%$ & $\begin{array}{c}\text { Adv. Mater. 2017, 29, } \\
1700001\end{array}$ \\
\hline PCN-NV4 & NRR & -- & 0 & $\begin{array}{c}0.6 \\
\mathrm{mmol} \mathrm{g}_{\mathrm{cat}}^{-1} \mathrm{~h}^{-1}\end{array}$ & -- & $11.6 \%$ & $\begin{array}{c}\text { Angew. Chem. Int. Ed. } 2018 \text {, } \\
\text { 57, } 10246\end{array}$ \\
\hline VN/TM & NRR & -- & 0 & $\begin{array}{l}1.2 \\
\mathrm{gNH}_{3}-\mathrm{N} \mathrm{m}^{-2} \mathrm{~d}^{-1}\end{array}$ & -- & $2.3 \%$ & $\begin{array}{l}\text { ACS Sustainable Chem. Eng. } \\
2018,6,9545\end{array}$ \\
\hline Ag nanosheet & NRR & -- & 0 & $\begin{array}{l}0.7 \\
\mathrm{gNH}_{3}-\mathrm{N} \mathrm{m}^{-2} \mathrm{~d}^{-1}\end{array}$ & -- & $4.8 \%$ & $\begin{array}{c}\text { Chem. Commun. 2018, 54, } \\
11427\end{array}$ \\
\hline NPC & NRR & -- & 0 & $\begin{array}{c}0.1 \\
\mathrm{mmol} \mathrm{g}_{\mathrm{cat}}^{-1} \mathrm{~h}^{-1}\end{array}$ & -- & $4.2 \%$ & $\begin{array}{c}\text { Chem. Commun. 2019, 55, } \\
687\end{array}$ \\
\hline Ru NPs & NRR & -- & 0 & $\begin{array}{c}0.1 \\
\mathrm{gNH}_{3}-\mathrm{N} \mathrm{m}^{-2} \mathrm{~d}^{-1}\end{array}$ & -- & $\sim 5.4 \%$ & $\begin{array}{c}\text { ChemSusChem 2018, } \\
11,3480\end{array}$ \\
\hline Black phosphorus nanosheet & NRR & -- & 0 & $\begin{array}{c}2.2 \\
\mathrm{mmol} \mathrm{g}_{\mathrm{cat}}^{-1} \mathrm{~h}^{-1}\end{array}$ & -- & $5.1 \%$ & $\begin{array}{c}\text { Angew. Chem. Int. Ed. 2019, } \\
\text { 58, } 2612\end{array}$ \\
\hline $\mathrm{Fe}_{3} \mathrm{O}_{4} / \mathrm{PANI} / \mathrm{N}-\mathrm{MWCNT}$ & NRR & -- & 0 & $\begin{array}{c}<0.1 \\
\mathrm{gNH}_{3}-\mathrm{N} \mathrm{m}^{-2} \mathrm{~d}^{-1}\end{array}$ & -- & $0.34 \%$ & $\begin{array}{l}\text { Sustain. Energy Fuels } 2019 \text {, } \\
\text { 3, } 431\end{array}$ \\
\hline Ru SAs/N-C & NRR & -- & 0 & $\begin{array}{c}8.6 \\
\mathrm{mmol} \mathrm{g}_{\mathrm{cat}}^{-1} \mathrm{~h}^{-1}\end{array}$ & -- & $29.6 \%$ & $\begin{array}{c}\text { Adv. Mater. 2018, 30, } \\
1803498\end{array}$ \\
\hline
\end{tabular}




\begin{tabular}{|c|c|c|c|c|c|c|c|}
\hline Ru SAs/g-C $\mathbf{C}_{3} \mathbf{N}_{4}$ & NRR & -- & 0 & $\begin{array}{c}1.6 \\
\mathrm{mmol} \mathrm{g}_{\mathrm{cat}}{ }^{-1} \mathrm{~h}^{-1}\end{array}$ & -- & $8.3 \%$ & $\begin{array}{c}\text { Adv. Funct. Mater. } 2019 \text {, } \\
1905665\end{array}$ \\
\hline N-doped porous carbon & NRR & -- & 0 & $\mathrm{mmol} \mathrm{g}_{\mathrm{cat}}^{-1} \mathrm{~h}^{-1}$ & -- & $1.4 \%$ & ACS Catal. 2018, 8, 1186 \\
\hline Boron-doped graphene & NRR & -- & 0 & $\begin{array}{c}2.4 \\
\mathrm{gNH}_{3}-\mathrm{N} \mathrm{m}^{-2} \mathrm{~d}^{-1}\end{array}$ & -- & $10.8 \%$ & Joule 2018, 2, 1610 \\
\hline CC-450 & NRR & -- & 0 & $\begin{array}{c}3.8 \\
\mathrm{gNH}_{3}-\mathrm{N} \mathrm{m}^{-2} \mathrm{~d}^{-1}\end{array}$ & -- & $6.9 \%$ & $\begin{array}{c}\text { Chem. Commun. 2018, 54, } \\
11188\end{array}$ \\
\hline$\beta$-FeOOH nanorod & NRR & -- & 0 & $\mathrm{mmol} \mathrm{g}_{\mathrm{cat}}^{-1} \mathrm{~h}^{-1}$ & -- & $6.7 \%$ & $\begin{array}{c}\text { Chem. Commun. 2018, 54, } \\
11332\end{array}$ \\
\hline$\beta F e O(O H, F)$ nanorod & NRR & -- & 0 & $\begin{array}{c}3.0 \\
\mathrm{mmol} \mathrm{g}_{\text {cat }}{ }^{-1} \mathrm{~h}^{-1}\end{array}$ & -- & $9.0 \%$ & $\begin{array}{c}\text { Chem. Commun. 2019, 55, } \\
3987\end{array}$ \\
\hline AuHNCs & NRR & -- & 0 & $\begin{array}{c}0.9 \\
\mathrm{gNH}_{3}-\mathrm{N} \mathrm{m}^{-2} \mathrm{~d}^{-1}\end{array}$ & -- & $30.2 \%$ & Nano Energy 2018, 49, 316 \\
\hline $\mathrm{Mo}_{2} \mathrm{C} / \mathrm{C}$ & NRR & -- & 0 & $\begin{array}{c}2.4 \\
\mathrm{mmol} \mathrm{g}_{\mathrm{cat}}{ }^{-1} \mathrm{~h}^{-1}\end{array}$ & -- & $1.1 \%$ & $\begin{array}{c}\text { Adv. Mater. } 2018,30, \\
1803694\end{array}$ \\
\hline PEBCD/C & NRR & -- & 0 & $\begin{array}{c}0.4 \\
\mathrm{gNH}_{3}-\mathrm{N} \mathrm{m}^{-2} \mathrm{~d}^{-1}\end{array}$ & -- & $2.9 \%$ & $\begin{array}{c}\text { J. Am. Chem. Soc. } 2017 \text {, } \\
\text { 139, } 9771\end{array}$ \\
\hline
\end{tabular}




\begin{tabular}{|c|c|c|c|c|c|c|c|}
\hline $\mathrm{Cr}_{2} \mathrm{O}_{3}$ hollow microspheres & NRR & -- & 0 & $\begin{array}{c}1.8 \\
\mathrm{mmol} \mathrm{g}_{\mathrm{cat}}^{-1} \mathrm{~h}^{-1}\end{array}$ & -- & $6.8 \%$ & ACS Catal. 2018, 8, 8540 \\
\hline $\mathrm{r}-\mathrm{CeO}_{2}$ nanorod & NRR & -- & 0 & $\mathrm{mmol} \mathrm{g}_{\mathrm{cat}}^{-1} \mathrm{~h}^{-1}$ & -- & $3.7 \%$ & $\begin{array}{c}\text { ACS Sustainable Chem. Eng. } \\
2019,7,2889\end{array}$ \\
\hline $\mathrm{Fe}_{2} \mathrm{O}_{3}$ nanorods & NRR & -- & 0 & $\begin{array}{c}1.1 \\
\mathrm{mmol} \mathrm{g}_{\mathrm{cat}}^{-1} \mathrm{~h}^{-1}\end{array}$ & -- & $0.9 \%$ & $\begin{array}{c}\text { ChemCatChem 2018, 10, } \\
4530\end{array}$ \\
\hline Boron-doped $\mathrm{TiO}_{2}$ & NRR & -- & 0 & $\begin{array}{c}1.0 \\
\mathrm{mmol} \mathrm{g}_{\mathrm{cat}}^{-1} \mathrm{~h}^{-1}\end{array}$ & -- & $3.4 \%$ & $\begin{array}{c}\text { ACS Sustainable Chem. Eng. } \\
2019,7,117\end{array}$ \\
\hline d-TiO 2 nanobelts & NRR & -- & 0 & $\begin{array}{c}1.5 \\
\mathrm{gNH}_{3}-\mathrm{N} \mathrm{m}^{-2} \mathrm{~d}^{-1}\end{array}$ & -- & $9.2 \%$ & Nanoscale 2019, 11, 1555 \\
\hline TiOn@RGO & NRR & -- & 0 & $\begin{array}{c}1.0 \\
\mathrm{mmol} \mathrm{g}_{\mathrm{cat}}^{-1} \mathrm{~h}^{-1}\end{array}$ & -- & $3.3 \%$ & $\begin{array}{c}\text { J. Mater. Chem. A 2018, 6, } \\
17303\end{array}$ \\
\hline $\mathbf{p A u} / \mathbf{N F}$ & NRR & -- & 0 & $\begin{array}{c}2.3 \\
\mathrm{gNH}_{3}-\mathrm{N} \mathrm{m}^{-2} \mathrm{~d}^{-1}\end{array}$ & -- & $13.4 \%$ & Small 2019, 15, 1804769 \\
\hline $\mathrm{SnO}_{2}$ particles & NRR & -- & 0 & $\begin{array}{c}1.8 \\
\mathrm{gNH}_{3}-\mathrm{N} \mathrm{m}^{-2} \mathrm{~d}^{-1}\end{array}$ & -- & $2.2 \%$ & $\begin{array}{c}\text { Chem. Commun. 2018, 54, } \\
12966\end{array}$ \\
\hline $\mathrm{Y}_{2} \mathrm{O}_{3}$ nanosheet & NRR & -- & 0 & $\begin{array}{c}1.3 \\
\mathrm{gNH}_{3}-\mathrm{N} \mathrm{m}^{-2} \mathrm{~d}^{-1}\end{array}$ & -- & $2.5 \%$ & $\begin{array}{l}\text { Ind. Eng. Chem. Res. 2018, } \\
\text { 57, } 16622\end{array}$ \\
\hline
\end{tabular}




\begin{tabular}{|c|c|c|c|c|c|c|c|}
\hline $\mathrm{TiO}_{2} / \mathrm{Ti}$ & NRR & -- & 0 & $\begin{array}{c}1.3 \\
\mathrm{gNH}_{3}-\mathrm{N} \mathrm{m}^{-2} \mathrm{~d}^{-1}\end{array}$ & -- & $2.5 \%$ & $\begin{array}{c}\text { ACS Appl. Mater. Interfaces } \\
2018,10,28251\end{array}$ \\
\hline $\begin{array}{c}\mathrm{CoFe}_{2} \mathrm{O}_{4} \\
\text { nanoclusters/graphene }\end{array}$ & NRR & -- & 0 & $\begin{array}{c}0.3 \\
\mathrm{gNH}_{3}-\mathrm{N} \mathrm{m}^{-2} \mathrm{~d}^{-1}\end{array}$ & -- & $6.2 \%$ & $\begin{array}{c}\text { Chem. Commun. 2019, 55, } \\
12184\end{array}$ \\
\hline $\mathrm{Fe}_{3} \mathrm{O}_{4} / \mathrm{Ti}$ & NRR & -- & 0 & $\begin{array}{c}0.8 \\
\mathrm{gNH}_{3}-\mathrm{N} \mathrm{m}^{-2} \mathrm{~d}^{-1}\end{array}$ & -- & $2.6 \%$ & Nanoscale 2018, 10, 14386 \\
\hline $\mathrm{Fe} / \mathrm{Fe}_{3} \mathrm{O}_{4}$ & NRR & -- & 0 & $\begin{array}{c}<0.1 \\
\mathrm{gNH}_{3}-\mathrm{N} \mathrm{m}^{-2} \mathrm{~d}^{-1}\end{array}$ & -- & $8.3 \%$ & ACS Catal. 2018, 8, 9312 \\
\hline \multicolumn{2}{|c|}{ Electrochemical Oxidation } & 0 & -- & -- & -- & $\begin{array}{c}383 \\
\mathrm{kWh} \mathrm{kg}^{-1} \\
\mathrm{~N}\end{array}$ & $\begin{array}{c}\text { Environ. Sci. Technol. 2016, } \\
\text { 50, 8780-8787 }\end{array}$ \\
\hline \multicolumn{2}{|l|}{ CDI } & 0 & $79 \%$ & -- & -- & $\begin{array}{c}49 \\
\mathrm{kWh} \mathrm{kg}^{-1} \\
\mathrm{~N}\end{array}$ & $\begin{array}{c}\text { Environ. Sci. Technol. 2018, } \\
\text { 52, 14275-14285 }\end{array}$ \\
\hline \multicolumn{2}{|c|}{ Bioelectrochemical systems } & 0 & 0 & -- & $44 \%$ & -- & $\begin{array}{c}\text { Environ. Sci. Technol. 2020, } \\
\text { 54, 3002-3011 }\end{array}$ \\
\hline \multicolumn{2}{|c|}{ Electrochemical stripping } & 0 & $93 \%$ & -- & -- & $\begin{array}{c}8.5 \\
\mathrm{kWh} \mathrm{kg}^{-1} \\
\mathrm{~N}\end{array}$ & $\begin{array}{c}\text { Environ. Sci. Technol. 2018, } \\
\text { 52, 1453-1460 }\end{array}$ \\
\hline \multicolumn{2}{|c|}{$\begin{array}{l}\text { Membrane electrode } \\
\text { coupled with microbial electrolysis }\end{array}$} & 0 & -- & -- & -- & $\begin{array}{c}1.6 \\
\mathrm{kWh} \mathrm{kg}^{-1} \\
\mathrm{~N}\end{array}$ & $\begin{array}{c}\text { Environ. Sci. Technol. 2018, } \\
52,8930-8938\end{array}$ \\
\hline
\end{tabular}


ENRRA $^{a}$ represents electrocatalytic nitrate reduction and recovery towards ammonia

ENRA $^{\mathrm{b}}$ represents electrochemical nitrate reduction

$\mathrm{NRR}^{\mathrm{c}}$ represents electrochemical nitrogen reduction reaction.

d. Ammonia recovery calculation is based on the ration of recovered ammonia/ammonium to ammonia/ammonium produced/containing. 
Table S2. The value and normalized value of peak current density and Tafel slope.

\begin{tabular}{cccccc} 
& $\begin{array}{c}\text { Peak current } \\
\text { density for } \\
\text { nitrate } \\
\text { reduction }\end{array}$ & $\begin{array}{c}\text { Normalized peak } \\
\text { current density } \\
\text { for nitrate } \\
\text { reduction }\end{array}$ & $\begin{array}{c}\text { Tafel slope for } \\
\text { HER (average } \\
\text { value of neutral } \\
\text { and alkaline } \\
\text { electrolyte) }\end{array}$ & $\begin{array}{c}\text { Reciprocal of } \\
\text { Tafel slope } \\
\text { for HER }\end{array}$ & $\begin{array}{c}\text { Normalized } \\
\text { Tafel slope for } \\
\text { HER }\end{array}$ \\
$\mathrm{Co}_{3} \mathrm{O}_{4}$ & 1.3 & 0.097 & 274 & 0.00365 & 0.60 \\
$\mathrm{P}_{-\mathrm{Co}_{3} \mathrm{O}_{4}}$ & $\mathbf{1 3 . 4}$ & $\mathbf{1 . 0}$ & 230 & 0.00435 & 0.68 \\
$\mathrm{CoP}$ & 8.8 & 0.66 & $\mathbf{1 5 6}$ & 0.00641 & $\mathbf{1 . 0}$ \\
$\mathrm{OP}-\mathrm{CoP}$ & 5.8 & 0.43 & 316 & 0.00316 & 0.49 \\
\hline
\end{tabular}


Table S3. The concentration of N species of Figure 2(f).

\begin{tabular}{cccccc} 
& $\begin{array}{c}{\mathrm{Remain} \mathrm{NO}_{3}}^{-} \\
(\mathrm{mM})\end{array}$ & $\begin{array}{c}\mathrm{NH}_{3} / \mathrm{NH}_{4}{ }^{+} \text {in } \\
\text { reaction cell } \\
(\mathrm{mM})\end{array}$ & $\begin{array}{c}\mathrm{NH}_{3} / \mathrm{NH}_{4}{ }^{+} \text {in } \\
\text { trap cell }(\mathrm{mM})\end{array}$ & $\mathrm{NO}_{2}{ }^{-}(\mathrm{mM})$ & $\mathrm{N}_{2}(\mathrm{mM})$ \\
$\mathrm{CoP}$ & $0.00 \pm 0.00$ & $0.39 \pm 0.04$ & $8.13 \pm 0.06$ & $0.00 \pm 0.00$ & $1.48 \pm 0.02$ \\
$\mathrm{OP}-\mathrm{CoP}$ & $0.05 \pm 0.00$ & $2.07 \pm 0.12$ & $5.26 \pm 0.12$ & $0.00 \pm 0.00$ & $2.62 \pm 0.07$ \\
$\mathrm{Co}_{3} \mathrm{O}_{4}$ & $0.07 \pm 0.05$ & $1.01 \pm 0.08$ & $6.40 \pm 0.04$ & $0.00 \pm 0.00$ & $2.52 \pm 0.06$ \\
$\mathrm{P}_{-} \mathrm{Co}_{3} \mathrm{O}_{4}$ & $0.00 \pm 0.00$ & $1.15 \pm 0.05$ & $6.62 \pm 0.06$ & $0.00 \pm 0.00$ & $2.22 \pm 0.04$ \\
$\mathrm{Pd}_{-} \mathrm{Cu}_{\mathrm{Cu}}$ & $0.03 \pm 0.01$ & $0.79 \pm 0.11$ & $4.10 \pm 0.05$ & $0.17 \pm 0.03$ & $4.91 \pm 0.10$ \\
$\mathrm{Ti}$ & $3.36 \pm 0.19$ & $1.43 \pm 0.13$ & $2.97 \pm 0.05$ & $0.57 \pm 0.03$ & $1.68 \pm 0.06$ \\
\hline
\end{tabular}


Table S4. Detail of adsorption free energy for nitrate and $\mathrm{H}$ at different sites on the CoP (211) crystal plane.

site adsorption free energy $(\mathrm{eV})$

${ }^{*} \mathrm{H}$

$* \mathrm{NO}_{3}$

A

0.42

$-2.27$

B

0.22

C

$\begin{array}{ll}-0.62 & -3.02\end{array}$

D
$-2.97$ 
Table S5. The Bader charge calculation results.

\begin{tabular}{cccc} 
& \multicolumn{3}{c}{ Bader Charge } \\
& before adsorption & after adsorption & $\Delta \mathrm{q}$ \\
\hline $\mathrm{Co} 1$ & 0.185345 & 0.363494 & -0.178149 \\
\hline $\mathrm{Co} 2$ & 0.191508 & 0.350778 & -0.15927 \\
$\mathrm{~N}$ & 0.830357 & 0.830746 & -0.000389 \\
$\mathrm{O} 1$ & -0.26819 & -0.5621 & 0.293906 \\
$\mathrm{O} 2$ & -0.29097 & -0.39103 & 0.100063 \\
\hline $\mathrm{O} 3$ & -0.2712 & -0.55767 & 0.286465 \\
\hline
\end{tabular}


Table S6. Formations energy barriers of different di-nitrogen species

\begin{tabular}{cc} 
Reaction & Energy barrier (eV) \\
$* \mathrm{NO} \stackrel{\mathrm{NO}_{2}^{-}}{\longrightarrow} * \mathrm{~N}_{2} \mathrm{O}_{3}$ & 2.28 \\
$* \mathrm{NO} H \stackrel{\mathrm{NO}_{-}^{-}}{\longrightarrow} * \mathrm{~N}_{2} \mathrm{O}_{2} \mathrm{OH}$ & 2.49 \\
$* N \stackrel{\mathrm{NO}_{2}^{-}}{\longrightarrow} * \mathrm{~N}_{2} \mathrm{O}_{2}$ & 2.90 \\
$* \mathrm{NH} \stackrel{\mathrm{NO}_{2}^{-}}{\longrightarrow} * \mathrm{~N}_{2} \mathrm{OOH}$ & 2.95 \\
$* \mathrm{NH}_{2} \stackrel{\mathrm{NO}^{-}}{\longrightarrow} * \mathrm{~N}_{2} \mathrm{O}+\mathrm{H}_{2} \mathrm{O}$ & 3.68 \\
\hline
\end{tabular}


Table S7. Compare of production/consumption ratio of $\mathrm{OH}^{-} / \mathrm{e}^{-}$.

\begin{tabular}{ccc} 
Reactions & $\begin{array}{c}\text { Production ratio } \\
\text { of } \mathrm{OH}^{-} / \mathrm{e}^{-}\end{array}$ & $\begin{array}{c}\text { Consumption ration } \\
\text { of } \mathrm{OH}^{-} / \mathrm{e}^{-}\end{array}$ \\
\hline $2 \mathrm{NO}_{3}{ }^{-}+6 \mathrm{H}_{2} \mathrm{O}+10 \mathrm{e}^{-} \rightarrow \mathrm{N}_{2}+12 \mathrm{OH}^{-}$ & 1.2 & $/$ \\
$\mathrm{NO}_{3}{ }^{-}+6 \mathrm{H}_{2} \mathrm{O}+8 \mathrm{e}^{-} \rightarrow \mathrm{NH}_{3}+9 \mathrm{OH}^{-}$ & 1.125 & $/$ \\
$2 \mathrm{H}_{2} \mathrm{O}+2 \mathrm{e}^{-} \rightarrow \mathrm{H}_{2}+2 \mathrm{OH}^{-}$ & 1 & 1 \\
$4 \mathrm{OH}^{-} \rightarrow \mathrm{O}_{2}+2 \mathrm{H}_{2} \mathrm{O}+4 \mathrm{e}^{-}$ & $/$ & $/$
\end{tabular}


Table S8. Formation energy barriers of $* \mathrm{NOOH}$ to $* \mathrm{NOHOH}$ and $* \mathrm{NO}$.

$\begin{array}{cc}\text { Reaction } & \text { Energy barrier }(\mathrm{eV}) \\ * \mathrm{NOOH} \rightarrow * \mathrm{NOHOH} & 0.65 \\ * \mathrm{NOOH} \rightarrow * \mathrm{NO} & 0.05\end{array}$




\section{Reference}

1. Yan, Z.; Jinhua, L.; Jing, B.; Xiaoyan, L.; Zhaoxi, S.; Ligang, X.; Shuai, C.; Qunjie, X.; Baoxue, Z., Total organic carbon and total nitrogen removal and simultaneous electricity generation for nitrogen-containing wastewater based on the catalytic reactions of hydroxyl and chlorine radicals. Applied Catalysis B: Environmental 2018, 238, S0926337318306441-.

2. Shih, Y.-J.; Wu, Z.-L.; Lin, C.-Y.; Huang, Y.-H.; Huang, C.-P., Manipulating the crystalline morphology and facet orientation of copper and copper-palladium nanocatalysts supported on stainless steel mesh with the aid of cationic surfactant to improve the electrochemical reduction of nitrate and $\mathrm{N}_{2}$ selectivity. Applied Catalysis B: Environmental 2020, 273, 119053. 3. Nayak, S.; Chaplin, B. P., Fabrication and characterization of porous, conductive, monolithic $\mathrm{Ti}_{4} \mathrm{O}_{7}$ electrodes. Electrochim. Acta 2018, 263, 299-310.

4. Teng, W.; Bai, N.; Liu, Y.; Liu, Y.; Fan, J.; Zhang, W.-x., Selective nitrate reduction to dinitrogen by electrocatalysis on nanoscale iron encapsulated in mesoporous carbon. Environ. Sci. Technol. 2017, 52, (1), 230-236.

5. Yin, F.; Liu, $\mathrm{H}$., The j-pH diagram of interfacial reactions involving $\mathrm{H}^{+}$and $\mathrm{OH}^{-}$. Journal of Energy Chemistry 2020, 50, 339-343.

6. Kuhl, K. P.; Cave, E. R.; Abram, D. N.; Jaramillo, T. F., New insights into the electrochemical reduction of carbon dioxide on metallic copper surfaces. Energy \& Environmental Ence 2012, 5, (5), 7050-7059.

7. Myland, J. C.; Oldham, K. B., Uncompensated Resistance. 1. The Effect of Cell Geometry. Anal. Chem. 2000, 72, (17), 3972-3980.

8. Bard, A., Electrochemical Merhods. Fundamentals and applications 1980, 290.

9. Segall, M. D.; Shah, R.; Pickard, C. J.; Payne, M. C., Population analysis of plane-wave electronic structure calculations of bulk materials. Physical Review B 1996, 54, (23), 16317-16320.

10. Perdew, J. P.; Burke, K.; Ernzerhof, M., Generalized Gradient Approximation Made Simple. Phys. Rev. Lett. 1996, 77, (18), 3865-3868.

11. Tang, W.; Sanville, E.; Henkelman, G., A grid-based Bader analysis algorithm without lattice bias. J. Phys.: Condens. Matter 2009, 21, (8), 084204.

12. Huo, X.; Van Hoomissen, D. J.; Liu, J.; Vyas, S.; Strathmann, T. J., Hydrogenation of aqueous nitrate and nitrite with ruthenium catalysts. Applied Catalysis B: Environmental 2017, 211, 188-198.

13. Chen, G.-F.; Yuan, Y.; Jiang, H.; Ren, S.-Y.; Ding, L.-X.; Ma, L.; Wu, T.; Lu, J.; Wang, H., Electrochemical reduction of nitrate to ammonia via direct eight-electron transfer using a copper-molecular solid catalyst. Nature Energy 2020, 5, (8), 605-613.

14. Wu, Z.-Y.; Karamad, M.; Yong, X.; Huang, Q.; Cullen, D. A.; Zhu, P.; Xia, C.; Xiao, Q.; Shakouri, M.; Chen, F.-Y., Electrochemical ammonia synthesis via nitrate reduction on Fe single atom catalyst. Nature Communications 2021, 12, (1), $1-10$.

15. Gao, J.; Jiang, B.; Ni, C.; Qi, Y.; Bi, X., Enhanced reduction of nitrate by noble metal-free electrocatalysis on P doped three-dimensional Co3O4 cathode: Mechanism exploration from both experimental and DFT studies. Chem. Eng. J. 2020, $382,123034$.

16. Tian, J.; Liu, Q.; Asiri, A. M.; Sun, X., Self-Supported Nanoporous Cobalt Phosphide Nanowire Arrays: An Efficient 3D Hydrogen-Evolving Cathode over the Wide Range of pH 0-14. J. Am. Chem. Soc. 2014, 136, (21), 7587-7590.

17. Peng, X.; Mi, Y.; Bao, H.; Liu, Y.; Qi, D.; Qiu, Y.; Zhuo, L.; Zhao, S.; Sun, J.; Tang, X.; Luo, J.; Liu, X., Ambient electrosynthesis of ammonia with efficient denitration. Nano Energy 2020, 78, 105321.

18. Zhao, X.; Lan, X.; Yu, D.; Fu, H.; Liu, Z.; Mu, T., Deep eutectic-solvothermal synthesis of nanostructured Fe3S4 for electrochemical N2 fixation under ambient conditions. Chem. Commun. 2018, 54, (92), 13010-13013. 